PERSPECTIVA HISTÓRICA DO CASAMENTO NO BRASIL: DO CASAMENTO CANÔNICO AO CASAMENTO CIVIL INTRODUZIDO PELO DECRETO N 181 DE 24 DE JANEIRO DE 1890

Dissertação de Mestrado

Orientador: Professor Titular Ignacio Maria Poveda Velasco

UNIVERSIDADE DE SÃO PAULO

FACULDADE DE DIREITO

São Paulo-SP

2020 


\section{PERSPECTIVA HISTÓRICA DO CASAMENTO NO BRASIL: DO CASAMENTO CANÔNICO AO CASAMENTO CIVIL INTRODUZIDO PELO DECRETO No 181 DE 24 DE JANEIRO DE 1890}

Dissertação de Mestrado apresentada à Banca Examinadora do Programa de Pós-Graduação em Direito da Faculdade de Direito da Universidade de São Paulo, na área de concentração Direito Civil (DCV), sob orientação do Professor Titular Ignacio Maria Poveda Velasco.

UNIVERSIDADE DE SÃO PAULO

FACULDADE DE DIREITO

São Paulo-SP

2020 
Catalogação da Publicação

Serviço de Biblioteca e Documentação

Faculdade de Direito da Universidade de São Paulo

Brito, Juliana Ribeiro Ugolini de

Perspectiva histórica do casamento no Brasil: do casamento canônico ao casamento civil. Introduzido pelo Decreto $n^{\circ} 181$ de 24 de janeiro de 1890 .

Juliana Ribeiro Ugolini de Brito ; orientador Ignacio Maria Poveda Velasco -- São Paulo, 2020.

$182 \mathrm{f}$

Tese (Doutorado - Programa de Pós-Graduação em Direito Civil) - Faculdade de Direito, Universidade de São Paulo, 2020

1. Casamento canônico. 2. Casamento civil. 3. Direito civil. I. Poveda Velasco, Ignacio Maria, orient. II. Título. 
Nome: BRITO, Juliana Ribeiro Ugolini de

Título: Perspectiva histórica do casamento no Brasil: do casamento canônico ao casamento civil. Introduzido pelo Decreto $\mathrm{n}^{\circ} 181$ de 24 de janeiro de 1890

Dissertação de Mestrado apresentada à Banca Examinadora do Programa de Pós-Graduação em Direito da Faculdade de Direito da Universidade de São Paulo, na área de concentração Direito Civil (DCV), sob orientação do Professor Titular Ignacio Maria Poveda Velasco.

Banca Examinadora

Prof. Dr.

Prof. Dr.

Prof. Dr. 
À minha FAMÍLIA, meu grande propósito, e sua ressignificação nesses últimos intensos três anos.

FERNANDO, meu marido, por estar sempre ao meu lado. ISABEL, minha filha, que fez o caminho ter muito mais sentido. A vocês, meu eterno amor e dedicação. 


\section{AGRADECIMENTOS}

Agradeço à Universidade de São Paulo e à sociedade paulista a oportunidade de estudo do qual resultou a presente dissertação.

Agradeço ao meu orientador, Professor Titular Ignacio Maria Poveda Velasco, a

quem registro minha profunda admiração por sua cultura, conhecimento e, acima de tudo, pelas infinitas manifestações de sensibilidade, ética e empatia que constituem exemplos a serem seguidos por todo docente.

Agradeço aos professores do Departamento de Direito Civil da Faculdade de Direito da Universidade de São Paulo, na pessoa dos Professores Dra. Maria Cristina da Silva Carmignani e Dr. João Alberto Schutzer Del Nero, que compuseram a banca de qualificação, obrigada pela contribuição de suas ponderações.

Agradeço à minha família todo o apoio, principalmente ao meu marido, Fernando, e à minha mãe, Roseli, e à minha irmã, Luciana, que supriram minhas ausências maternas para que essa pesquisa pudesse ser concluída. 
E, sobre tudo isto, revesti-vos de amor, que é o vínculo da perfeição.

Colossenses 3:14 


\section{RESUMO}

Esta dissertação aborda os aspectos histórico-jurídicos do casamento no Brasil do século XVI ao XIX e as permanências de suas características até os dias atuais. Divide-se a pesquisa em dois maiores momentos. Um primeiro, em que o casamento era exclusivamente canônico e regido pela jurisdição eclesiástica, salvo alguns efeitos englobados na "justiça do homem", em especial nas Ordenações Filipinas. Um segundo momento, a partir da secularização da matéria com a introdução do casamento civil pelo Decreto $n^{\circ} 181$ de 24 de janeiro de 1890. Seguindo todo esse percurso, permaneceram os conceitos e as características essenciais do casamento, como se pode verificar na legislação hoje vigente.

Palavras-chave: Casamento religioso. Casamento civil. Secularização. Decreto no 181 de 24 de janeiro de 1890 . 


\begin{abstract}
This dissertation addresses the historical-legal of marriage in Brazil from the 16th to the 19th century and the continuity of its characteristics to this present day. This research is divided into two major moments. Firstly, how marriage was exclusively canonical and governed by ecclesiastical jurisdiction, saved for some effects encompassed by the "justice of man", especially on the Philippine Ordinances, and in a second moment from the secularization of the matter with the introduction of civil marriage by the Decree No. 181 posted on January $24^{\text {th }}, 1890$. Following all this course, it remained the essential concepts and characteristics of marriage, as can be seen in current legislation.
\end{abstract}

KEYWORDS: Religious marriage. Civil marriage. Secularization. Decree No. 181 posted on January $24^{\text {th }}, 1890$. 


\section{CONTEXTO SOCIOLÓgICO DO CASAMENTO NO BRASIL NOS} SÉCULOS XVI E XIX

2. CASAMENTO CANÔNICO NO BRASIL ANTES DO ADVENTO DO CASAMENTO CIVIL 25

2.1. Ordenações do Reino de Portugal e legislações do império .................................... 25

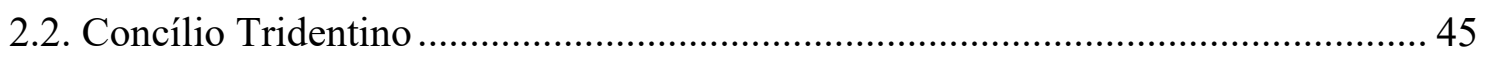

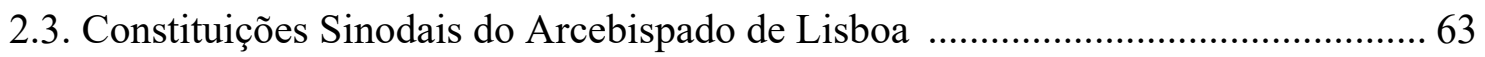

2.4. Constituições Primeiras do Arcebispado da Bahia .................................................. 67

2.4.1. Constituições Primeiras do Arcebispado da Bahia............................................ 69

3. SECULARIZAÇÃO DO CASAMENTO NO BRASIL ........................................ 83

3.1. Projetos legislativos e discussões sobre a secularização do casamento.................. 83

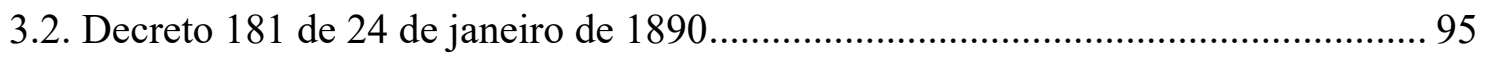

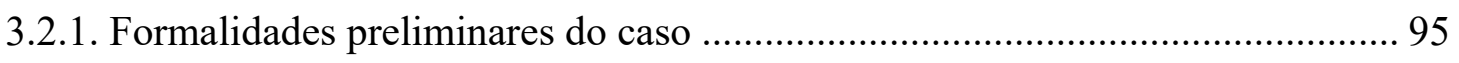

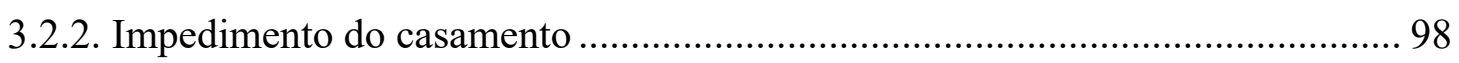

3.2.3 Celebração do casamento ........................................................................... 102

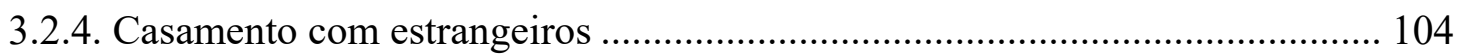

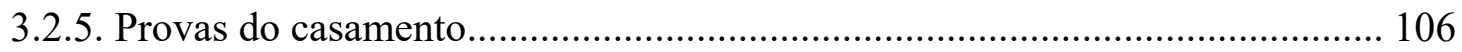

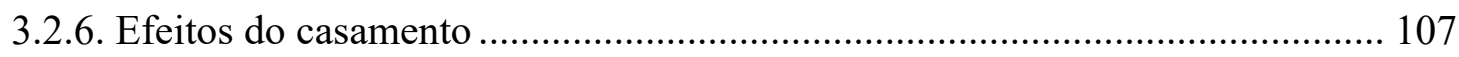

3.2.7. Casamento nulo e do anulável e Divórcio .................................................... 113

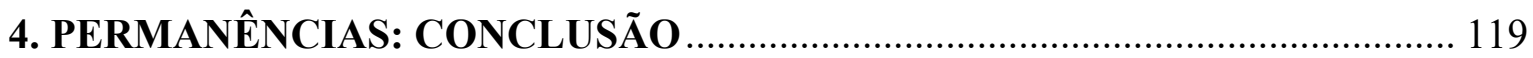

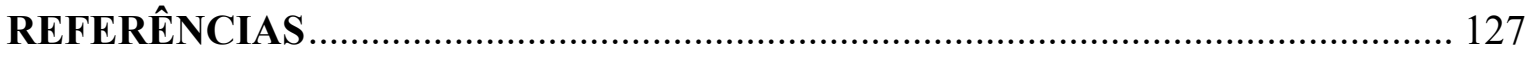

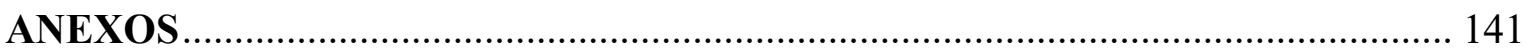




\section{INTRODUÇÃO}

Quando falamos de família, uma das ideias que nos vêm à mente é o casamento, instituto bastante singular que enseja estudos de naturezas psicológica, sociológica, antropológica, filosófica, religiosa e jurídica.

Não obstante as inúmeras teorias acerca da evolução do homem em sociedade, e sabendo-se que não seria possível a aplicação de uma regra única para todos os povos primitivos existentes, o fato é que o imperativo de se associar gerou a família e a sociedade na configuração em que hoje estamos inseridos.

LECLERCQ observa que existe uma espécie de acordo universal do gênero humano, que se explica pelo próprio caráter da instituição familiar, e que a família nasce espontaneamente pelo simples desenvolvimento da vida humana ${ }^{1}$.

ROUSSEAU, em "Do Contrato Social", pondera que a mais antiga de todas as sociedades, e a única natural, é a família, cuja primeira lei consiste em velar pela própria conservação. Especificamente sobre o casamento, compreende-o como um contrato que produz efeitos e sem os quais seria impossível que a sociedade subsistisse ${ }^{2}$.

Apesar de estar contratada, a vida em sociedade é uma imposição da natureza, e, num foco mais específico, a família também. Por essa razão, o objeto do presente estudo, delimitado na história do casamento no Brasil, não é outro que não analisar uma das formas de constituição de família.

A forma natural de se formar uma família consiste na união sexual do homem com a mulher. Independentemente da realidade de coexistência com outras diversas formas de união ou mesmo de sentimento de família, a união heterossexual, da qual advém a procriação natural, é inerente à maioria das espécies animais.

Ocorre que, para os homo sapiens, a simples cópula propagadora da espécie não garante a criação dos filhos, nem a transferência de conhecimentos vitais para a evolução humana, tampouco a ordem social, essencial para a própria coexistência dos seres humanos em sociedade.

\footnotetext{
${ }^{1}$ LECLERCQ, Jacques. A familia. Trad. Emérico da Gama. São Paulo: Editora Quadrante; Editora da Universidade de São Paulo, 1968. p. 9.

${ }^{2}$ ROUSSEAU, Jean-Jacques. Do Contrato social: princípios do Direito Político. São Paulo: Editora CID, 2005. p. $2-3 ; 187$.
} 
Como meio de garantir o cumprimento do quanto contratado para a vida em sociedade, adveio a criação de normas para todo o contexto familiar, incluindo-se a oficialização da relação sexual. Regulamentou-se a vida do indivíduo, passando-se a se exigir a fidelidade recíproca, e lançaram-se à clandestinidade as relações que não obtivessem a sua anuência no seio do casamento.

O casamento como forma natural de constituição familiar existia antes do surgimento da Igreja Católica, tendo sido preservado pelas mais diversas religiões e pelas legislações civis nas nações pelo mundo. É um instituto inerente ao ser humano e que transcende as regras culturais delimitadas pelo tempo e o espaço, sempre mantendo a sua essência de constituição familiar.

No ocidente, a história do casamento está intimamente ligada à história do Direito do Império Romano e da Igreja Católica.

Para o Direito Romano, o consentimento dos cônjuges era o mero estado de fato que perdurava enquanto persistisse a intenção deles em permanecer casados. Nas palavras de BONFANTE, o matrimônio romano poderia ser definido pela "convivência do homem e da mulher sob a autoridade do marido com a intenção efetiva, contínua, de serem marido e mulher"3. Assim, eram dois os seus requisitos: a convivência e a intenção marital (affectio maritalis $)^{4}$. A convivência, a vida em comum, era o requisito objetivo. E, por sua vez, a intenção marital era o requisito subjetivo. Conforme pontua MOREIRA ALVES, o consentimento - ao contrário do que ocorre nos contratos - não era apenas inicial, mas sim duradouro e contínuo, preferindo os romanos, para designá-lo, a expressão affectio. O honor matrimonni, ou seja, o se tratar em sociedade como marido e mulher fazia presumir a existência de casamento. Concorrendo ambos os requisitos, surgia o matrimônio; na falta de um deles, era dissolvido 5 .

\footnotetext{
${ }^{3}$ BONFANTE, Pietro. Corso di diritto romano: diritto di famiglia. Milano: Giuffrè, 1963. v. 1, p. 256.

${ }^{4}$ Trata-se de forma reduzida e superficial da análise do casamento no Direito Romano, que se estendeu por longo período e sofreu modificações acerca da matéria ao longo dos séculos. Sobre o tema ver: MARKY, Thomas. Curso elementar de direito romano. 2. ed.. São Paulo: Resenha Tributária, 1974; CRETELLA JUNIOR, José. Curso de direito romano. 6. ed. Rio de Janeiro: Forense, 1978; ORESTANO, Riccardo. La struttura giuridica del matrimonio romano - Dal diritto classico al dirittto giustininaeo. Roma: Universitá Gregoriana Editrice, 1970; MOREIRA ALVES, José Carlos. Direito romano. 18. ed. rev. Rio de Janeiro: Forense, 2018; MOREIRA ALVES. A natureza jurídica do casamento romano no direito clássico, referida a seguir.

${ }^{5}$ MOREIRA ALVES, José Carlos. A natureza jurídica do casamento romano no Direito Clássico. p. 7. Disponível em: www.revistas.usp.br/rfdusp/article/download/67287/69897. Acesso em: 11 jul. 2017.
} 
Na Igreja primitiva não há comprovação de uma forma especificamente cristã do matrimônio. Os católicos se associam aos costumes do contexto, em que não havia a necessidade de adicionar práticas eclesiásticas próprias. VAINFAS analisa que a moral cristã nos primeiros séculos, oscilante entre o combate e a defesa do matrimônio, contribuiu para essa situação de celebração doméstica ${ }^{6}$.

No século V, a teologia cristã já estava mais sistematizada. As escrituras tidas como verdadeiras tinham sido escolhidas, e a autoridade do bispo de Roma, reconhecida, basicamente pelo desaparecimento da ingerência do Estado nas questões eclesiásticas, motivadas pela queda do Império Romano no Ocidente.

Santo Agostinho, o mais importante teólogo do século V, traz em seu tratado Os bens do matrimônio as questões sobre o valor social da união entre homem e mulher e sintetiza o que chamou de bens do matrimônio: a prole, a fidelidade e o sacramento ${ }^{7}$.

Para Santo Agostinho, o fim do matrimônio é, antes de tudo, a procriação. Sua visão reflete a cultura pós-moderna em que inserido, em que a necessidade de cultivar os campos, de manter um grande exército para sustentar a dominação e de ocupar os espaços era latente.

A Alta Idade Média foi marcada por produção escrita e falada sobre casamento, destacam-se a Moralia e Regulae Pastorales do Papa Gregório, o Grande (590-604); e os Decretais Pontificiais e dos Estatutos Episcopais dos séculos VIII a X.

É de se notar a Carta Ad consulta Vestra do Papa Nicolau I, de novembro de 866, que, respondendo aos búlgaros que o consultaram sobre os ritos sacramentais do matrimônio na Igreja do Ocidente, depois de descrever os ritos matrimoniais, acrescentou:

\footnotetext{
mas se faltar alguma destas circunstâncias, não se segue daí que nisso haja necessariamente um pecado, como vós imaginais, na igreja grega. Fazer todos esses preparativos não cabe às vezes nos recursos da pobreza, e é por isto que bastará, em conformidade das leis (civis), o mútuo consenso, nos consórcios daqueles de quem falais.
}

\footnotetext{
${ }^{6}$ VAINFAS, Ronaldo. Casamento, amor e desejo no ocidente cristão. 2. ed. São Paulo: Ática, 1992. p. 34.

${ }^{7}$ AgOSTINHO, Santo. Patrística. Dos bens do Matrimônio. A Santa Virgindade. Dos bens da viuvez: Cartas a Proba e a Juliana. São Paulo: Paulus, [s.d.]. Disponível em: https://ortodoxia.pt/data/Patristica-16.pdf. Acesso em: 18 jul. 2017.
} 
Os séculos XI a XIII foram marcados pelos concílios ${ }^{8}$ regionais e ecumênicos e, gradativamente, a matéria de matrimônio foi sendo discutida e regulamentada pela Igreja.

O I Concílio de Latrão, em 1123, proibiu o casamento entre parentes de sangue, ainda sem especificar os graus de proibição (cânone 5) ${ }^{9}$, e por clérigos em grandes ordens (cânone $21)^{10}$. O IV Concílio de Latrão, em 1215, restringiu a proibição do casamento para o limite de quarto grau de consanguinidade ou afinidade (cânone 50); proibiu o casamento clandestino (cânone 51); e rejeitou o testemunho indireto como prova de casamento.

O monopólio jurisdicional em matéria de casamento é absorvido oficialmente pela Igreja na Summa Elegantius in iure divino, também conhecida por Summa Coloniensis ${ }^{11}$, de 1169. Na França, no Concílio de Bourges, em 1286, foi ordenado que os eclesiásticos anulassem os casamentos ilegais, separando os cônjuges, quem quer que eles fossem.

Também os estatutos sinodais das dioceses se tornaram fontes de regulamentação específica do matrimônio, principalmente na adaptação dos costumes locais às regras fundamentais da Igreja.

Ainda no século XIII, TOMÁS DE AQUINO dispôs em sua Suma Teológica que o matrimônio era um sacramento constituído por três elementos:

a sua causa, a sua essência e os seus efeitos. Levando em conta esses três elementos, podemos classificar as três definições que se deram do matrimônio. Assim, a de $\mathrm{Hugo}^{12}$ considera a causa, isto é, o consentimento; e essa definição é clara. A definição dada pelo Mestre considera a essência do matrimônio, isto é, a união. E acrescenta um objeto determinado quando diz: entre pessoas idôneas. Também indica a diferença específica dessa união quando diz - marital. Pois, sendo o matrimônio uma união em vista de um fim determinado, a sua espécie se determina pelo fim a que se ordena, e este depende do marido. Enuncia também a força dessa união, que é indissolúvel, quando diz: Que mantém

\footnotetext{
${ }^{8}$ Concílio provém do latim “concilium”, reunião, assembleia. É a reunião de bispos e outros dignitários eclesiásticos, feita com regularidade, para tratar e legislar matérias de interesse da igreja.

9“cânon 5: Proibimos casamentos entre parentes de sangue porque eles são proibidos pelas leis divinas e seculares. Aqueles que contraem tais alianças, como também seus descendentes, as leis divinas não apenas ostracizam, mas declaram amaldiçoados, enquanto as leis civis as classificam como infames e privam-nas de direitos hereditários. Nós, portanto, seguindo o exemplo de nossos pais, declaramos e os estigmatizamos como infames."

${ }^{10}$ Cânon 21: Nós absolutamente proibimos sacerdotes, diáconos, subdiáconos e monges de ter concubinas ou contrair matrimônio. Decretamos de acordo com as definições dos cânones sagrados, que os casamentos já contraídos por tais pessoas devem ser dissolvidos e que as pessoas sejam condenadas a fazer penitência.

${ }^{11}$ Estudada pela versão de: FRANSEN, Gérard; KUTTNER, Stephan. Summa "Elegantius in iure diuino" seu Coloniensis. Oxford: Fordham University Press, 1969.

${ }^{12}$ Segundo AQUINO, Hugo Victoria definia o matrimônio como: a "união de duas pessoas idôneas fundadas num consentimento legítimo" (AQUINO, Santo Tomás. Suma Teológica. Art. 3ㅇ $§ 4$. Disponível em https://sumateologica.wordpress.com/dowload. Acesso em: 20 abr. 2017).
} 
entre os cônjuges um mesmo regime de vida. A outra definição ${ }^{13}$ enfim considera o efeito, a que o matrimônio se ordena, a saber, a vida doméstica em comum. E como toda sociedade se funda em alguma lei, por isso a definição enuncia a lei reguladora dessa sociedade, a saber, o direito divino e o humano ${ }^{14}$.

O século XIV é de crise generalizada na Europa também em matéria de casamento. O costume medieval português, de maior relevância para esse estudo em razão da colonização brasileira, respeitou o uso romano do casamento como sendo um simples acordo entre as partes, solenizado ou não por rituais religiosos, enquanto a Igreja pregava a instituição do casamento como indissolúvel.

Foi nesse contexto de instabilidade e crises na Europa que o Concílio Tridentino se reuniu em sessões entre os anos de 1545 e 1563. O matrimônio foi formalmente reconhecido como um dos sete sacramentos ${ }^{15}$ instituídos por Cristo e ganhou formulação perante o Direito Canônico. Assim, o sacramento do matrimônio elevou ao plano sobrenatural a instituição natural do casamento.

Muito da formulação advinda do Concílio Tridentino subsiste até hoje, não só perante o Direito Canônico, mas também perante o Direito Civil Brasileiro. E acredita-se que essa é a principal relevância do presente estudo: entender a origem no Brasil do que hoje enxergamos por casamento, sendo esse um dos institutos de formação de uma família.

LE PLAY, um dos fundadores da sociologia e das pesquisas sobre estruturas familiares, adotou como método de estudo partir do exame da família como unidade elementar para construir um sistema sociológico. Como organização básica da sociedade, sobre a família monta-se e em torno dela gravita toda a vida dos indivíduos. ${ }^{16}$

ESPÍNOLA em Introdução ao estudo do direito civil aborda a visão sociológica de SOROKIN, pela qual o objeto da sociologia é o estudo da relação e das correlações entre as diversas classes de fenômenos sociais (correlação entre os fenômenos econômicos e religiosos, entre a família e a moral, entre o jurídico e o econômico, entre a mobilidade e a

\footnotetext{
${ }^{13}$ Ainda segundo AQUINO, "outros"” definiam o matrimônio como: "o consórcio de uma vida em comum, que comunica o direito divino e o humano” (AQUINO, Santo Tomás. Suma Teológica, cit., Art. $3^{\circ}, \S 4$ ).

${ }^{14}$ AQUINO, Santo Tomás. Suma Teológica, cit., Art. $3^{\circ}$.

${ }^{15}$ A Igreja Católica celebra sete sacramentos, que são: batismo, confirmação (ou crisma), eucaristia, reconciliação (ou penitência), unção dos enfermos, ordem e matrimônio.

${ }^{16}$ BOTELHO, Tarcísio Rodrigues. A família na obra de Frédéric Le Play. Dados [online]. 2002, v. 45, n. 3, p.513-544. Disponível em: http://dx.doi.org/10.1590/S0011-52582002000300007. Acesso em: 20 jul. 2017.
} 
política, etc.); em segundo lugar, a correlação entre os fenômenos sociais e não sociais (geográficos, biológicos, etc.); em terceiro lugar, o estudo dos caracteres gerais comuns a todas as classes de fenômenos sociais ${ }^{17}$.

O direito é um fenômeno social e, como tal, deve ser examinado na sociedade. Não é movido pelo puro raciocínio do homem, mas pelas necessidades do povo; vive nas suas condições tanto econômicas como psicológicas, tanto materiais como morais. Por isso muda de acordo com o povo, o lugar, o tempo ${ }^{18}$.

A evolução social não deixa dúvidas acerca da função do casamento e da intervenção da autoridade pública nas organizações familiares. A força da coação sobre as regras que regem o casamento varia, às vezes tendendo para um afrouxamento e, em outras tantas, para um rigorismo. Celebrado o casamento e originada a fonte da obrigação a ele atinente, o nosso contrato social atribuiu à autoridade do poder público a intervenção na organização familiar, descrita pelo Direito de Família.

E, para tais efeitos, através dos tempos, o casamento tomou formas e aspectos mais ou menos solenes, mais ou menos rigorosos, conforme a maior ou menor necessidade de implantar-se como segurança própria à família.

E é dessa indagação que surgiu a proposta do presente estudo sobre a evolução histórica do casamento no Brasil, em sua esfera jurídica e com recorte temporal até o momento da sua secularização, de forma que o objeto desta pesquisa é, no primeiro momento, o casamento regido exclusivamente pelo Direito Canônico; e, no segundo, a efetiva entrega da matéria para o Direito Civil Brasileiro, por meio do Decreto 181 de 24 de janeiro de 1890.

Para compreender o direito em sua essência e finalidade, é indispensável considerálo no meio em que está inserido. Assim, equivocado seria o estudo acerca do casamento no Brasil do século XVI ao XIX da ótica das percepções jurídico-moral-sociais atuais.

Portanto, em razão do recorte histórico-temporal deste estudo, considerar-se-á a concepção do matrimônio que vigorava à época. E, sem a pretensão de ser um estudo sociológico, que não é o objeto nem expertise deste trabalho, no primeiro capítulo abordamos superficialmente a vida social em torno do casamento no período em tela, que engloba da

\footnotetext{
${ }^{17}$ ESPINOLA, Eduardo; ESPINOLA FILHO, Eduardo. Introdução ao estado do direito civil. Introdução ao estudo do direito civil. São Paulo: Freitas Bastos, 1939. v. 1, p. 15.

${ }^{18}$ COGLIOLO, Pietro. Philosophia do direito privado. Vertida da segunda edição italiana com o consentimento do autor por Eduardo Espinola. Bahia: Empreza, 1898, $§ 2^{\circ}$.
} 
colonização até o início da República Velha (regime que vigorava quando da secularização do casamento). Não nos ateremos às relações indígenas e escravas por possuírem circunstâncias próprias a cada grupo àquela época.

No segundo capítulo, adentramos ao tema do casamento em si, quando ainda regido no Brasil exclusivamente pelo Direito Canônico. O Concílio de Trento que, recepcionado pelo Reino de Portugal, estabeleceu regras, normas, padrões e procedimentos pertinentes ao casamento, decretou a rigorosa observância de certas solenidades externas, tendentes a conferir ao casamento toda a necessária publicidade e consequente garantia.

São abordadas as disposições legislativas relacionadas ao casamento, especialmente Ordenações do Reino de Portugal.

No início do século XVIII, refletindo a teologia moral em vigor e sintetizando as ideologias religiosas majoritárias à época, advieram no Brasil as Constituições Primeiras do Arcebispado da Bahia, publicadas em 1707, que estabeleceram os cânones que nos regeriam. Segundo as palavras do então arcebispo Dom Sebastião Monteiro da Vide, as Constituições foram promulgadas para "o bom governo do Arcebispado, direção dos costumes, extirpação dos vícios e abusos, moderação dos crimes e recta administração da justiça"19.

As Constituições Primeiras do Arcebispado da Bahia basearam-se nas tradições bíblicas, nas constituições portuguesas e nas diretrizes do Concílio Tridentino, de forma adaptada à situação colonial ${ }^{20}$.

No terceiro capítulo serão abordadas as discussões sobre a secularização do casamento e projetos legislativos a respeito. Trataremos do Decreto 181 de 24 de janeiro de 1890, que instituiu o casamento civil no Brasil. Discorreremos, ainda nessa esfera, sobre os temas do casamento constantes de tal decreto, tais como formalidades preliminares, impedimentos, celebração, casamento estrangeiro, efeitos do casamento, divórcio e nulidade.

No quarto capítulo, serão apresentados elementos relativos ao casamento que permanecem até hoje em nosso costume e nossa legislação.

\footnotetext{
${ }^{19}$ VIDE, Dom Sebastião Monteiro de. Constituições Primeiras do Arcebispado da Bahia (1707). Brasília, DF: Senado Federal, 2007. Disponível em: http://www2.senado.leg.br/bdsffitem/id/222291. Acesso em: 20/11/2016.

${ }^{20}$ CASIMIRO, Ana Palmira Bittencourt Santos. Constituições Primeiras do Arcebispado da Bahia: Educação, Lei, Ordem e Justiça no Brasil Colonial. Disponível em: http://www.histedbr.fe.unicamp.br/navegando/artigos_pdf/Ana_Palmira_Casimiro1_artigo.pdf. Acesso em: 05 mar. 2017.
} 
Para este estudo, realizamos pesquisas bibliográfica e documental no Brasil e em Portugal. No Brasil, foram feitas consultas na cidade de São Paulo, especialmente em unidades da biblioteca da Universidade de São Paulo e da Pontifícia Universidade Católica. A parte da pesquisa realizada em Portugal se deu especificamente na Faculdade de Direito da Universidade de Lisboa e na Biblioteca Nacional de Portugal. Além disso, foram consultadas obras digitalizadas disponibilizadas na internet.

A pesquisa documental foi feita no Arquivo da Cúria Metropolitana de São Paulo e no Arquivo do Estado de São Paulo.

$\mathrm{Na}$ esfera do Direito Canônico, que regrava o casamento no Brasil até a sua secularização, os diplomas mais relevantes acerca da matéria são os Decretos do Concílio Tridentino, as Constituições Sinodais do Arcebispado de Lisboa e as Constituições Primeiras do Arcebispado da Bahia.

No âmbito legislativo, o estudo da matéria no direito luso-brasileiro inicia-se com as Ordenações do Reino de Portugal. Quando do descobrimento do Brasil, vigoravam na metrópole as Ordenações Afonsinas, promulgadas em 1446, que tiveram pouca divulgação pelo fato de terem suas edições apenas manuscritas e pouca relevância sobre a matéria de casamento no Brasil, porquanto nesse primeiro período ainda não havia uma significativa colonização.

Em 1521 foram promulgadas as Ordenações Manuelinas, que vigoraram até 1603, quando revogadas pelas Ordenações Filipinas, que incorporaram boa parte da legislação precedente.

Em 1890 adveio o Decreto 181, introduzindo o casamento civil no Brasil, acrescido de decretos e leis mais específicos que serão abordados ao longo deste trabalho.

A metodologia científica para análise do material colhido teve como base os métodos histórico, dialético-doutrinário e dedutivo.

Para a apresentação formal do presente trabalho científico, foram utilizadas as normas de formatação definidas pela Associação Brasileiras de Normas Técnicas (ABNT). $\mathrm{Na}$ hipótese em que não há previsão da $\mathrm{ABNT}$, as notas de rodapé e a referência foram elaboradas em coerência com as demais determinações. 


\section{PERMANÊNCIAS: CONCLUSÃO}

O casamento é um instituto natural ao homem, que transcende às regras culturais delimitadas pelo tempo e espaço, sempre mantendo sua essência de constituição familiar. É claro que, como instituto também social, reflete e se adequa ao seu contexto, motivo pelo qual sofre algumas modificações em sua forma ou efeitos. O casamento, como fonte de constituição familiar, existia antes da Igreja Católica e se manteve nas mais diversas religiões e legislações civis nas nações pelo mundo.

A existência do casamento é observada ainda no seio da família antiga, formada ao redor da religião doméstica. Cada família tinha suas próprias cerimônias, festas particulares, fórmulas de orações, sendo esse conjunto considerado patrimônio familiar, propriedade sagrada de cada família que com ninguém podia partilhar. Era apenas transmitida de geração à geração, na linha masculina, participando a mulher nesse culto por intervenção primeiro de seu pai, depois de seu marido. Nessa religião existia um culto exacerbado aos mortos que só podia ser prestado pela própria família. Acreditava-se que o morto só aceitava a oferenda quando esta lhe fosse prestada das mãos dos seus, assim, o morto que não deixasse filhos, não receberia oferendas e ficaria sujeito à fome eterna, o que reflete a importância da descendência na religião primitiva ${ }^{226}$.

Por força dessas crenças, o celibato era proibido. Porém, não ser celibatário e gerar filhos não era suficiente, pois aquele que seria o continuador da religião domestica deveria ser concebido de pais unidos em casamento religioso. Ao filho tido fora do casamento era vedado oferecer o banquete fúnebre, e a família não se perpetuaria por seu intermédio ${ }^{227}$.

Para COULANGES, “o fim do casamento para a religião e para as leis estaria na união de dois seres no mesmo culto doméstico, fazendo deles nascer um terceiro, apto a continuar esse culto" 228 .

Etimologicamente, matrimônio, matris munus (ou mumium) destaca a função, o ofício, a tarefa maternal da mulher (do latim: mater, mãe, e munus ou munium ofício), no seio da família.

\footnotetext{
${ }^{226}$ COULANGES, Fustel. A cidade antiga. Trad. de Fernando de Aguiar. 5. ed. São Paulo: Martins Fontes, 2005. p. 53-55.

${ }^{227}$ Id. Ibid., p. 53-55.

${ }^{228}$ Id. Ibid., p. 55.
} 
Os doutrinadores brasileiros, cientes de que o conceito de casamento não é imutável por acompanhar o dinamismo dos fatos sociais, o contextualizam com a realidade temporal e aos pressupostos jurídicos do mesmo ${ }^{229}$.

Assim é que vemos essa contextualização do instituto do casamento na doutrina pátria, sendo que cada obra, cada manifestação de ideia acerca do tema reflete o seu tempo e sociedade, mas sendo observada a permanência da percepção de que o casamento liga a família.

Esse amoldamento do instituto do casamento pelas modificações sociais, podem ser compreendidas da sua respectiva conceitualização pelos doutrinadores ao longo do tempo. BEVILAQUA (1859-1944), no contexto do início do século XX conceitua que:

O casamento é um contrato bilateral e solene, pelo qual um homem e uma mulher se unem indissoluvelmente, legalizando por ele suas relações sexuais, estabelecendo a mais estreita comunhão de vida e de interesses, e comprometendo-se a criar e educar a prole que de ambos nascer ${ }^{230}$.

LAFAYETTE (1834-1917), inserido no mesmo recorte temporal, sintetizou o casamento como ato solene pelo qual duas pessoas de sexo diferente se unem para sempre, com a promessa recíproca de fidelidade no amor e da mais estreita comunhão de vida ${ }^{231}$

PONTES DE MIRANDA (1892-1979) definiu casamento como um contrato solene, pelo qual duas pessoas de sexo diferente e capazes, conforme a lei, se unem com o instituto de conviver toda a existência, legalizando por ele, a título de indissolubilidade do vínculo, as suas relações sexuais, estabelecendo para seus bens, à sua escolha ou por imposição legal, um dos regimes regulados pelo Código Civil e, comprometendo-se a criar, educar a prole que de ambos nasceu. ${ }^{232}$

GONÇALVES (1938-...) já após no contexto em que o casamento estava se amoldando à igualdade entre os cônjuges que veio a ser declarada na Constituição Federal de 1988, anota que "é impossível ser original diante de tantas definições, antigas e modernas.

\footnotetext{
${ }^{229}$ LOTUFO, Renan. Direito civil constitucional. São Paulo: Malheiros, 2002. p. 32.

${ }^{230}$ BEVILAQUA, Clovis. Direito da família, cit., p. 34.

${ }^{231}$ PEREIRA, Lafayette Rodrigues. Direitos de família. Rio de Janeiro: Freitas Bastos, 1956, p. 29.

${ }^{232}$ PONTES DE MIRANDA, Francisco Cavalcanti. Direito de família. Rio de Janeiro: Jacintho Ribeiro dos Santos Ed., 1917. p. 15.
} 
Mas, falta, às definições apresentadas, a noção de contrato, essencial ao conceito moderno e à forma igualitária do casamento atual" ${ }^{\prime 233}$.

A Exposição de Motivos do Supervisor da Comissão Revisora e Elaboradora do Código Civil, Doutor Miguel Reale, datada de 16 de janeiro de 1975 mostra o embate social da época em que se discutia a modernização sobre a questão da igualdade entre os cônjuges, em que se definiu pela supressão do termo "poder marital"234.

O conceito de matrimônio para a Igreja Católica atual é de consortium totius vitae (Cânon 1055, $\S 1^{\text {o }}$, do Código de Direito Canônico de 25 de janeiro de 1983): em que o pacto matrimonial, pelo qual o homem e a mulher constituem entre si o consórcio de toda a vida, por sua índole natural ordenado ao bem dos cônjuges e à geração e educação da prole entre batizados foi por Cristo Senhor elevado à dignidade de sacramento.

A demonstrar que as alterações que a instituição casamento passou ao longo do tempo são meros ajustes para que possa refletir o seu contexto social, mas que a sua essência segue mantida, elaborou-se quadro comparativo das três principais legislações a respeito do tema no Brasil: (i) Decreto n 181 de 1890, (ii) Código Civil de 1916, e (iii) Código Civil de 2002 (com as respectivas alterações legislativas), que segue como Anexo II a este trabalho.

O que se verifica do quadro comparativo é que a estrutura da habilitação e celebração do casamento, os impedimentos matrimoniais e os efeitos do casamento seguem

\footnotetext{
${ }^{233}$ GONÇALVES, Carlos Roberto. Direito civil brasileiro. São Paulo: Saraiva, 2007. p. 22.

234“"Tais contradições da crítica ocorreram especialmente no que se refere à posição dos cônjuges, parecendo aos tradicionalistas um grave erro o abandono da natural preeminência que deveria ser assegurada ao marido, a cobra de qualquer contrasteação; em franco contraste, pois, com os defensores da absoluta igualdade entre os esposos, a ponto de condenarem quaisquer disposições tendentes a proteger a mulher no seio da familia. Entre esses dois extremos situa-se o Anteprojeto, que põe termo ao 'poder marital', pois não se pode dizer que este subsista só pelo fato de caber ao marido a direção da sociedade conjugal, visto como ele só poderá exercer com a colaboração da mulher, no interesse do casal e dos filhos. Além do mais, essa direção sofre limitações expressas, conforme resulta da análise conjunta das seguintes diretivas: 1) As questões essenciais são decididas em comum, sendo sempre necessária a colaboração da mulher na direção da sociedade conjugal. A mulher, em suma, deixa de ser simples colaboradora e companheira-consoante posição que lhe atribui a lei vigente - para passar a ter 'poder da decisão' conjuntamente com o esposo. 2) Prevalecem as decisões tomadas pelo marido, em havendo divergência, mas fica ressalvada à mulher a faculdade de recorrer ao juiz, desde que não se trate de matéria personalíssima. 3) O domicílio do casal é escolhido por ambos os cônjuges, e não apenas pelo marido, como dispõe o Código atual, que se limita a conferir à mulher a faculdade de recorrer ao juiz, no caso de deliberação que a prejudique, de conformidade com a redação dada ao seu art. 233 pela Lei $n^{\circ} 4.121$, de 27 de agosto de 1962, que dispõe sobre a situação jurídica da mulher casada. 4) Pode a mulher, assim como o marido, ausentar-se do domicílio conjugal para atender a encargos públicos, ao exercício de sua profissão, ou a interesses particulares relevantes; 5) $O$ exercício do pátrio poder compete a ambos os cônjuges, com a mesma configuração jurídica consagrada pela lei atual; 6) Cabe à mulher, como norma geral, a administração dos bens próprios". EXPOSIÇÃO de Motivos do Supervisor da Comissão Revisora e Elaboradora do Código Civil, Doutor Miguel Reale, datada de 16 de janeiro de $1975 . \quad$ Disponível http://www.emerj.tjrj.jus.br/revistaemerj_online/edicoes/anais_onovocodigocivil/anais_especial_1/Anais_P arte_I_revistaemerj_9.pdf. Acesso em: 03 jan. 2020.
} 
consolidados. As diferenças mais substanciais que tivemos para que o instituto se adaptação à sociedade à qual está inserido dizem respeito à possibilidade do divórcio e igualdade dos direitos entre os cônjuges.

Além das legislações supramencionadas, a linha do tempo das demais regulamentações concernentes à matéria de casamento também demonstram essa movimentação no sentido de amoldamento do instituto ao contexto social.

No período do Brasil colonial, o direito português reconhecia como válidos três tipos de casamento: a) o realizado perante a autoridade religiosa; b) o denominado de "marido conhecido ou pública fama" em que havia publicidade, pois era realizado na presença de testemunhas, mas sem intervenção da autoridade religiosa, o qual se caracterizava pela coabitação e tratamento mútuo e recíproco como marido e mulher; e c) o de consciência ou à morganheira, em que não havia publicidade, homem e mulher viviam maritalmente, porém esta relação era considerada ilícita.

Essas uniões subsistiram até o Alvará de 12 de setembro de 1564 que instituiu a aplicação do Concílio de Trento.

No Brasil colônia, frente às dificuldades para efetuar o casamento, tais como dificuldades e valores para obtenção dos documentos etc, muitas pessoas casavam na clandestinidade.

Com esforço especial para a regulamentação das matérias acerca do casamento, as Constituições Primeiras do Arcebispado da Bahia trouxeram e adaptaram as normas do Concílio Tridentino para a realidade da colônia.

O Brasil se tornou independente de Portugal em 1822 e promulgou suas primeira Constituição em 1824, pela qual determinava que a religião católica-apostólica-romana era a oficial do Brasil, e que a conduta dos indivíduos deveria ser direcionada pelos princípio católicos.

O Decreto de 3 de novembro de 1827 confirmou a legítima tutela da Igreja sob o matrimônio. Com isso, os casamentos acatólicos não gozavam do prestígio social que permeava os casamentos feitos perante a Igreja Católica.

No período imperial nossa legislação civil reconhecia três formas de casamento: o católico, celebrado conforme os preceitos do Concílio Tridentino e a Constituição do Arcebispado da Bahia; o misto, casamento entre católicos e não católicos; contraído segundo 
as formalidades do direito canónico; e o não católico ou acatólico, entre pessoas que professavam diferente religião, havido conforme o preceito de suas respectivas religiões.

No século XIX, com o crescimento de não acatólicos no Brasil, advieram os Breves como forma de autorizar, de forma limitada, a celebração destes casamentos.

Em 1863, a Lei 1.144 foi regulamentada através do Decreto de 17 de abril, que embora legitimasse o casamento de pessoas não católicas, ainda não trazia a previsão do casamento civil em si.

Com a instituição do Decreto ${ }^{\circ} 111$-A de 7 de janeiro de 1890, o Estado tornou-se laico e não confessional, ou seja, foi reconhecida a liberdade religiosa.

Após conturbadas manifestações sociais contra e a favor do casamento civil, diversas movimentações legislativas, foi instituído o Decreto $n^{\circ} 181$ de 24 de janeiro de 1890, pelo qual passou a vigorar no Brasil o casamento civil, revogando a Lei 1.144 de 11 de setembro de 1861 e o seu decreto regulamentar de 17 de abril de 1863 que dispunha sobre os casamentos não católicos.

Em 26 de junho de 1890, o Governo Provisório baixou o Decreto $n^{\circ}$ 521, proibindo a celebração do casamento religioso em momento anterior ao civil

O casamento civil recebeu reforço legal na Constituição de 1891. Os Decretos $n^{\circ}$ 181 e 521 de 1890 vigoraram até 1917, quando da entrada em vigor do Código Civil de 1916.

Para BEVILÁQUA, autor do projeto que instituiu o Código Civil de 1916, o casamento civil é - a rigor e simplesmente - aquele celebrado e reconhecido exclusivamente pelo estado mas reconhecia que a discussão a respeito do divórcio transcendia os limites do jurídico, alcançado as esferas da moral e dos costumes.

No Código Civil de 1916, o papel da mulher espelhava a sociedade da época. A família se identificava pelo nome do homem, sendo a mulher obrigada a adotar o sobrenome do marido. A mulher ao casar tornava-se relativamente capaz, pois os poderes de administração da vida passavam ao marido, chefe da família.

O casamento constituía a família legítima. Os vínculos extramatrimoniais eram punidos. A filiação legítima era advinda do casamento, sendo os filhos tidos fora da instituição nominados de naturais, adulterinos ou incestuosos, todos ilegítimos.

O rol impeditivo do casamento no Código Civil de 1916 era extenso e bem próximo do direito canônico. Eram 16 causas impeditivas, classificadas no artigo 183 por sua 
gravidade e efeitos jurídicos: a) dirimentes absolutos (incisos I a VIII), que geral nulidade do casamento; b) dirimentes relativos (incisos IX a XII), que geral anulabilidade; c) impedimentos meramente proibitivos, impedientes ou precautórios (incisos XIII a XVI), com penalidades só civis aos contraentes, como regime da separação obrigatória de bens ou multa pecuniária.

Passou-se a prever o desquite, mas ainda sem ruptura do vínculo matrimonial.

A Constituição Federal de 1.934 trouxe previsão expressa sobre o casamento civil indissolúvel. E a Lei $\mathrm{n}^{\circ} 379$ de 16 de janeiro de 1937 regulamentava os efeitos civis do casamento religioso e previa sanção penal para que contraísse outro casamento civil ou religioso com efeitos civis, depois de celebrado casamento religioso.

A Constituição Federal de 10 de novembro de 1937 limitou-se a declarar que o casamento era indissolúvel, não deixando claro se a Lei no 379 teria sido revogada ou não.

A Constituição de 18 de setembro de 1946 abordou matéria acerca do casamento em seu artigo 163, tendo sido acompanhada pela Constituição de 24 de janeiro de 1967e pela Emenda Constitucional $n^{\circ} 1$ de 27 de outubro de 1969 sobre as respectivas formalidades.

A Lei $\mathrm{n}^{\circ} 1.110$ de 23 de maio de 1950, que regia os efeitos do casamento religioso, previa que, concluída a habilitação, era facultado aos noivos se casarem perante a autoridade civil ou ministro religioso.

A Lei n ${ }^{\circ} 4.121$ de 27 de agosto de 1962 instituiu o Estatuto da Mulher Casada, devolvendo a plena capacidade à mulher, que passou à condição de colaboradora na administração da sociedade conjugal. Foi dispensada a necessidade de autorização do marido para o trabalho da esposa e foi instituído o que se chamou de bens reservados, que se constituía do patrimônio adquirido pela esposa com o produto do seu trabalho. Esses bens não respondiam pelas dívidas do marido, ainda que presumivelmente contraídas em benefício da família.

A Emenda Constitucional $n^{0} 9$ de 28 de junho de 1977, conhecida como Lei do Divórcio inseriu o divórcio como causa de término da sociedade conjugal, ainda com algumas limitações

A Constituição Federal de 1988 passa a conferir proteção à família em geral, quer oriunda do casamento, quer oriunda de união estável, quer seja monoparental. Também passa 
a ditar a igualdade entre os cônjuges, entre os filhos havidos dentro do casamento ou de qualquer outra forma.

A Constituição Federal de 1988 reconhece o casamento religioso, emprestando-lhe efeitos civis quando observados os termos da lei. Assim, o casamento religioso fica equiparado ao casamento civil quando cumpridas as formalidades legais. Do contrário, sob a ótica secular, trata-se de união estável e não de casamento civil.

A Lei 7.841 de 17 de outubro de 1989 revogou o artigo 38 da Lei do Divórcio, eliminando a restrição à possibilidade de divórcios sucessivos.

A Lei 11.441 de 4 de janeiro de 2007 permitiu a via extrajudicial para divórcio e separação consensual quando o casal não possui filhos menores de idade ou incapazes.

A Lei 12.036 de $1^{\circ}$ de outubro de 2009 modificou a Lei de Introdução ao Código Civil (artigo $7^{\circ}, \S 6^{\circ}$ ) compatibilizando o lapso temporal do divórcio realizado no estrangeiro com a sistemática constitucional.

Em 2010 foi aprovada a Emenda Constitucional $n^{\circ}$ 66, modificando o $§ 6^{\circ}$ do artigo 226 da Constituição Federal de 1988 instituindo o divórcio direto no Brasil, ou seja, suprimindo o requisito de prévia separação judicial ou mais de um ano ou de comprovada separação de fato por mais de dois anos.

Em 2013, precedida de decisões judiciais de 2011 que reconheceram a união estável entre pessoas do mesmo sexo, a Resolução no 175 do Conselho Nacional de Justiça determinou que os cartórios do país passassem a proceder à habilitação e celebração do casamento entre pessoas do mesmo sexo o que, sem a devida alteração legislativa, acabou por autorizar o casamento entre pessoas do mesmo sexo no país.

Assim, vemos que o instituto do casamento vai se adaptando às demandas da sociedade em que inserido, mas sem perder a sua essência existente desde as famílias primitivas. 


\section{REFERÊNCIAS}

AgostinHO, Santo. Patrística. Dos bens do Matrimônio. A Santa Virgindade. Dos bens da viuvez: Cartas a Proba e a Juliana. São Paulo: Paulus, [s.d.]. Disponível em: https://ortodoxia.pt/data/Patristica-16.pdf. Acesso em: 18 jul. 2017.

ALMEIDA, Ângela Mendes. Sexualidade e casamento na colonização portuguesa o Brasil. Análise Social, vol. XXII (92-93), 1986-3º-4º p. 697-705.

ALMEIDA, Candido Mendes de. Auxiliar jurídico (servindo de appendice à décima quarta edição do Código Philipino ou Ordenações do Reino de Portugal). Rio de Janeiro: Typographia do Instituto Philomathico, 1869.

ALMEIDA, Candido Mendes de. Ordenações e leis do Reino de Portugal. Recopiladas por Mandado D’El-Rey D. Philippe I. Rio de Janeiro: Typographia do Instituto Philomathico, 1870.

ALMEIDA, Fortunato de. História da Igreja em Portugal. Tomo III, parte II. Coimbra: 1915.

ANCHIETA, Pe. José de. Informação dos casamentos dos índios do Brasil. Revista do Instituto Histórico e Geográfico Brasileiro, t. 8, p. 254-262, 1867.

ANCHIETA, Pe. José de. Informações e fragmentos históricos do padre (...)(1584-1586) Rio de Janeiro, 1886.

ANDRADA, Diogo de Paiva de. Casamento perfeito. 2. ed. Lisboa: Livraria Sá da Costa, 1944.

ANNAES da Camara dos Deputados, 1858. Disponível em: http://bd.camara.gov.br/bd/handle/bdcamara/35025. Acesso em: 12 set. 2019.

AQUINO, Santo Tomás. Suma Teológica. Disponível em https://sumateologica.wordpress.com/dowload. Acesso em: 20 abr. 2017.

ARAÚJO, Alexandre Herculano de Castilho E. Estudos sobre o casamento civil. Lisboa: Bertrand; Francisco Alves: 186?

ARAÚJO, Manoel do Monte Rodrigues de. Elementos de direito ecclesiastico publico e particular. (Das Cousas Ecclesiasticas). Rio de Janeiro: Antonio Gonçalves Guimarães \& $\mathrm{C}^{\mathrm{a}}, 1858$, t. II .

ARAÚJO, Vicente Ferrer de Barros Wanderley; SOUSA, J. L. de. O casamento civil collecção das cartas do snr. Vicente Ferrer em resposta ao snr. Visconde de Seabra. Porto: Imprensa Popular de J. L. de Sousa, 1866.

ARRUDA, João. Do casamento. São Paulo: Typ. C. Manderbach, 1911. 
BANDEIRA FILHO, A. H. de Souza. Commentario a lei n. 1144 de 11 de setembro de 1861 e subsequente legislação sobre casamento de pessoas. Rio de Janeiro: Perseverança: 1876.

BARTMANN, Bernhard. Teologia dogmática. 2. ed. Trad. Vicente Pedroso. São Paulo: Editora Paulinas, 1962. t. 1.

BENTO XIV. Encíclica Satis Vobis Compertum. Disponível em: https://w2.vatican.va/content/benedictus-xiv/it/documents/enciclica--i-satis-vobiscompertum--i--17-novembre-1741--il-pont.html. Acesso em: 22 dez. 2017.

BEVILAQUA, Clovis. Direito da família. 7. ed. São Paulo: Livraria Editora Freitas Bastos, 1976.

BIANCA, Massimo. Dirito civile: la famiglia. 4. ed. Milano: Giuffrè, 2005.

BIONDI, Biondo. Diritto romano. Bologna: Ed. LicinioCapelli, 1957.

BITTAR, Carlos Alberto. Direito de família. Rio de Janeiro: Forense Universitária, 1991.

BLUTEAU, D. Raphael. Vocabulario portuguez e latino. Coimbra: Collegio das Artes da Companhia de Jesus, 1712.

BOLOGNE, Jean-Claude. História do casamento no Ocidente. Tradução de Isabel Cardeal. Camarate: Circulo de Leitores, 2000.

BONFANTE, Pietro. Corso di diritto romano. I. Milano, 1963.

BONFANTE, Pietro. Corso di diritto romano: diritto di famiglia. Milano: Giuffrè, 1963. v. 1 .

BOTELHO, Tarcísio Rodrigues. A família na obra de Frédéric Le Play. Dados [online]. v. 45, n. 3, p.513-544, 2002. Disponível em: http://dx.doi.org/10.1590/S001152582002000300007 . Acesso em: 20 jul. 2017.

BRAGA, Isabel Drumond. O Brasil setecentista como cenário da bigamia: estudos em homenagem a Luís Antônio de Oliveira Ramos. Faculdade de Letras da Universidade do Porto, 2004.

BRAMÃO, Alberto. Casamento e divórcio. Lisboa: Livraria Central de Gomes de Carvalho Editor, 1908:

BRASIL. Decreto de 3 de novembro de 1827. Declara em effectiva observancia as disposições do Concilio Tridentino e da Constituição do Arcebispado da Bahia sobre matrimonio. In: COLLECÇÃO de Leis do Império do Brazil de 1827. Parte Primeira. Rio de Janeiro: Typographia Nacional, 1878.

BRASIL. Senado Federal. Anais do Senado. Annaes do Senado do Império do Brazil, anno $1869 . \quad$ Livro $1 . \quad$ Disponível em: https://www.senado.leg.br/publicacoes/anais/pdf/Anais_Imperio/1869/1869\%20Livro\%20 1.pdf. Acesso em: 01 ago. 2017. 
BRASIL. Senado Federal. Anais do Senado. Annaes do Senado do Império do Brazil, anno 1887. Livro $1 . \quad$ Disponível em: https://www.senado.leg.br/publicacoes/anais/pdf/Anais_Imperio/1887/1887\%20Livro\%20 1.pdf. Acesso em: 01 ago. 2017.

CAETANO, Marcello. História do Direito Português. Lisboa: 1941.

CAETANO, Marcello. Recepção e execução dos decretos do concílio de Trento em Portugal. Separata da Revista da Faculdade de Direito da Universidade de Lisboa. Lisboa, v. 19, 87, p. 1965.

CALVINO, João. As Institutas ou Tratado da Religião Cristã. v. 2. Disponível em http://www.protestantismo.com.br/institutas/joao_calvino_institutas2.pdf. Acesso em: 10 jul. 2017.

CAMPOS, Alzira Lobo de Arruda. Casamento e família em São Paulo colonial: caminhos e descaminhos. Coord. Paula Porta. São Paulo: Paz e Terra, 2003.

CAMPOS, Diogo Leite de. A nova família. In: TEIXEIRA, Sálvio de Figueiredo (Org.) Direitos da família e do menor. 3. ed. Belo Horizonte: Del Rey, 1993.

CARNEIRO FILHO, Humberto João. Entre leis e cânones: a marcha da secularização do casamento no Brasil (1822-1916). Tese (Doutorado) - Universidade Federal de Pernambuco, Recife, 2018.

CARNEIRO, Manuel Borges. Direito civil de Portugal. Lisboa: Typ. Maria da Madre de Deus, 1858. t. II. Disponível em: http://purl.pt/705. Acesso em 12 nov. 2019.

CARREIRO, João Emanuel; SOARES, João Miguel; COUTO, Manuel Antônio; SALETE DA SILVA, Maria de La. Namoro e casamento em Rio Tinto na passagem do século: (1890 - 1910). Revista da Faculdade de Letras. História, n. 3, p. 223-224, 2002.

CARVALHO, Joaquim Coelho de. Direito civil - casamento, regimes matrimoniais, divorcio e separação, poder parental, tutela e princípios gerais. Coimbra: Liv Neves, 1915.

CASIMIRO, Ana Palmira Bittencourt Santos. Constituições Primeiras do Arcebispado da Bahia: Educação, Lei, Ordem e Justiça no Brasil Colonial. Disponível em: http://www.histedbr.fe.unicamp.br/navegando/artigos_pdf/Ana_Palmira_Casimiro1_artigo. pdf. Acesso em: 05 mar. 2017.

COELHO, Ludgero Antonio. Do casamento civil brazileiro comentário ethico jurídico ao decreto $n 181$ de 24 de janeiro de 1890. Rio de Janeiro: Pereira Braga: 1899.

COELHO, Rômulo. Direito de família - doutrina e jurisprudência. São Paulo: LEUD, 1990.

COGLIOLO, Pietro. Philosophia do direito privado. Vertida da segunda edição italiana com o consentimento do autor por Eduardo Espinola. Bahia: Empreza, 1898.

COMPARATO, Fábio Konder. A afirmação histórica dos direitos humanos. 3. ed. São Paulo: Saraiva, 2003. 
CONCILIO DE TRENTO. Em Latim, e Portuguez. Tomo I. Lisboa: João Baptista Reycend,1781. Disponível em http://purl.pt/360/4/. Acesso em: 20 nov. 2016.

CONCILIO DE TRENTO. Em Latim, e Portuguez. Tomo II. Lisboa: João Baptista Reycend, 1781, disponível em http://purl.pt/360/4/. Acesso em: 20 nov. 2016.

CONSTITUIÇÕES DO ARCEBISPADO DE LISBOA. assi as antigas como as extrauagantes primeyras e segundas. - Agora nouamente impressas... Lisboa: por Belchior Rodrigues: vendense na rua noua em casa de Ioam Lopez, 1588. Disponível em: http://docvirt.com/docreader.net/BibliotecaRuiBarbosa/20096. Acesso em: 29 dez. 2019.

CONSTITUIÇÕES Synodaes do Bispado do Porto ordenadas pelo muyto illustre... senhor Dom frey Marcos de Lisboa, bispo do dito bispado \&c. [sic]. - Agora nouamente acrecentadas com o Estilo da Iustiça. Coimbra: por Antonio de Mariz: á custa de Giraldo Mendez, liureiro, 1585. Disponível em: http://purl.pt/15043/3/. Acesso em: 29 dez. 2019.

CORDEIRO, Antonio Menezes. Divórcio e casamento na I República: questões fraturantes como arma de conquista e de manutenção do poder pessoal? Lisboa, [s.d.].

COULANGES, Fustel. A cidade antiga. Trad. de Fernando de Aguiar. 5. ed. São Paulo: Martins Fontes, 2005.

CRETELLA JUNIOR, José. Curso de direito romano. 6. ed. Rio de Janeiro: Forense, 1978.

CRUZ, Conde de Santa. Representação do exmo.revmo.sr. Arcebispo da Bahia, Conde de Santa Cruz, dirigida a'scamaras legislativas do império do Brasil a'cerca da proposta do governo sobre o casamento civil. Lisboa: Typographia de G. M. Martins: 1865.

DAVID, René. Os grandes sistemas do direito contemporâneo. São Paulo: Martins Fontes, 1986.

DEL PRIORE, Mary. (Org.). História das mulheres no Brasil. São Paulo: Contexto, 2015.

DEL PRIORE, Mary. História da gente brasileira: colônia. São Paulo: LeYa, 2016. v. 1.

DEL PRIORE, Mary. Histórias e conversas de mulher: amor, sexo, casamento e trabalho em mais de 200 anos de história. São Paulo: Planeta, 2014.

DENZINGER, Heinrich; HÜNERMANN, Peter. Compêndio dos símbolos, definições e declarações de fé e moral. São Paulo: Editora Loyola, 2007.

DEUS, Frei Gaspar da Madre de. Memórias para a história da Capitania de S. Vicente, hoje chamada de S. Paulo. São Paulo, 1953.

DIAS, José Alves; OLIVEIRA, Renata Soraya Bahia. "Casamento e Divórcio nas Constituições Primeiras do Arcebispado da Bahia: O caso de Lívia da Purificação" in XI Colóquio do Museu Pedagógico. Disponível em http://periodicos.uesb.br/index.php/cmp/article/viewFile/4895/4691. Acesso em: 14 jul. 2017. 
DIAS, Paula Barata. A influência do Cristianismo no conceito de casamento e de vida privada na Antiguidade Tardia. Revista Ágora, Estudos Clássicos em Debate 6, p. 99-133, 2004.

ELLIS Júnior, Alfredo. Resumo da história de São Paulo: quinhentismo e seiscentismo. São Paulo: Tipografia Brasil, 1942.

ESPINOLA, Eduardo. A família no direito civil brasileiro. Rio de Janeiro: Gazeta Judiciária Editora, 1954.

ESPINOLA, Eduardo; ESPINOLA FILHO, Eduardo. Introdução ao estado do direito civil. Introdução ao estudo do direito civil. São Paulo: Freitas Bastos, 1939. v. 1.

ESPINOLA, Eduardo; ESPINOLA FILHO, Eduardo. Tratado de direito civil brasileiro: introdução ao Estudo de Direito Civil. São Paulo: Freitas Bastos, 1939. v. 1.

EXPOSIÇÃO de Motivos do Supervisor da Comissão Revisora e Elaboradora do Código Civil, Doutor Miguel Reale, datada de 16 de janeiro de 1975. Disponível em: http://www.emerj.tjrj.jus.br/revistaemerj_online/edicoes/anais_onovocodigocivil/anais_esp ecial_1/Anais_Parte_I_revistaemerj_9.pdf.

FERNANDES, Maria de Lurdes Correia. Espelhos, cartas e guias: casamento e espiritualidade na Península Ibérica (1450-1700). Porto: Instituto de Cultura Portuguesa, Faculdade e Letras da Universidade do Porto, 1995.

FERREIRA, Maria de Fátima C. M. O casamento civil e o divórcio 1865-1910. Dissertação (Mestrado) - Instituto de Ciências Sociais na Universidade do Minho, Portugal. Minho: 1993.

FERREIRA, Waldemar Martins. História do direito brasileiro. Rio de Janeiro: Livraria Freitas Bastos, 1952. t. 2.

FRANCO, Francisco de Melo. Medicina teológica ou súplica humilde, feita a todos os senhores confessores e diretores, sobre o modo de proceder com seus penitentes na emenda dos pecados, principalmente da lascívia, cólera e bebedice. Lisboa, 1974.

FRANSEN, Gérard; KUTTNER, Stephan. Summa "Elegantius in iure diuino" seu Coloniensis. Oxford: Fordham University Press, 1969.

FREITAS, Augusto Teixeira de. Consolidação das Leis Civis. 2. ed. Rio de Janeiro: Typographia Universal de Laemmert, 1865.

FREITAS, Teixeira de. Consolidações das Leis Civis. Brasília, DF: Senado Federal, 2003. v. 1. Ed. fac símile. Diponível em: http://www2.senado.leg.br/bdsf/item/id/496206. Acesso em: 11 mar. 2017.

GAMA, Manuel de Azevedo Araújo e. Estudo sobre o casamento civil. Coimbra: Piza e Almeida, 1881. 
GARNIER, Paul. O matrimonio. Considerado nos seus deveres, relações e effeitos conjugaes sob o ponto de vista legal, hygienico, physiologico e moral. Rio de Janeiro: Livraria Garnier, [s.d.].

GOMES, Orlando. Direito de família. Atualizado por Humberto Theodoro Jr. 14. ed. Rio de Janeiro: Forense, 2001.

GOMES, Orlando. Raizes Históricas e Sociológicas do Código Civil brasileiro. 2. ed. São Paulo: Martins Fontes, 2003.

GONÇALVES, Carlos Roberto. Direito civil brasileiro. São Paulo: Saraiva, 2007.

GONÇALVES, Luiz da Cunha. Tratado de direito civil, em comentários ao Código Civil Português. 2. ed. São Paulo. Max Limonad-Editor, 1957. v. 6, t. 1.

GRIMAL, P. O amor em Roma. São Paulo: Martins Fontes, 1991

GUIMARÃES, José Jorge Alves. A evolução normativa do casamento nas constituições sinodais. Mestrado em História da Colonização e Migrações: Portugal - Brasil. Minho: 1999.

GUIMARÃES, José Jorge Alves. A evolução normativa do Casamento nas Constituições Sinodais. Mestrado em História da Colonização e Migrações: Portugal - Brasil. Minho: 1999.

HENRION, Baron. Historia General de la Iglesia: desde la predicacion de los apostoles, hasta el Pontificado de Gregorio XVI, tomo III, Madrid: 1852, p. 699-713. Disponível em: https://play.google.com/books/reader?id=4VlqGpyzx 5sC\&hl=pt-

BR\&printsec $=$ frontcover\&pg=GBS.PP1. Acesso em: 01 nov. 2019.

HENRIQUES, Orlando José Guerra. Matrimónio: a sacramentalidade de um sacramento diferente. 2014. Dissertação (Mestrado) - Faculdade de Teologia da Universidade Católica Portuguesa, Porto, 2014.

HERCUlano, Alexandre. Estudos sobre o casamento civil. Por ocasião do opúsculo do Sr. Visconde de Seabra sobre estes assuntos. 2. ed. Lisboa: 1892.

HOLZEM, Andreas. Bases europeias para uma confessionalização católica. In: KAUFFMANN, Thomas et al. (Org.). História Ecumênica da Igreja 2: da alta Idade Média até o início da idade Moderna. São Paulo: Edições Loola, 2014.

JEDIN, Hubert. Historia del Concilio de Trento. Navarra: Universidad de Navarra, 1975. v. 3.

KLUG, João. Imigração no Sul do Brasil. In: GRINBERG, Keila; SALLES, Ricardo (Orgs.). O Brasil Imperial: 1870-1889. Rio de Janeiro: Civilização brasileira, 2009. v. 3, .

LARA, Silvia Hunold. Ordenações Filipinas: Livro V. São Paulo: Companhia das Letras, 1999. 
LE PLAY, Frederic. Les théories sociologiques contemporaines, 1938.

LECLERCQ Ordenações do Reino de Portugal. Revista da Faculdade de Direito da Universidade de São Paulo, São Paulo, v. 89, p. 11-67, 1994.

LECLERCQ, Jacques. A família. Trad. Emérico da Gama. São Paulo: Editora Quadrante; Editora da Universidade de São Paulo, 1968.

LEERS, Bernadino O. F. M. Matrimônio e divórcio na Igreja Católica. Petrópolis: Vozes, 1978.

LEITE, Antonio S. J. Competência da Igreja e do Estado sobre o matrimônio. Porto: Livraria Apostolado da Imprensa, 1946.

LEITE, Eduardo de O. Tratado de Direito de Família: Origem e evolução do casamento. Curitiba: Juruá, 1991, v. L.

LEITE, Serafim, S. I. Cartas dos primeiros jesuítas do Brasil (1556-1563). São Paulo Comissão do IV Centenário da Cidade de São Paulo, 1958

LEMOS, Carlos Cesar. O casamento no Paraná: séculos XVIII e XIX. Dissertação de Mestrado apresentado ao Departamento de História da Universidade Federal do Paraná. Curitiba: 1987.

LEMOS, Miguel. Casamento civil representação enviada à Câmara dos Deputados contra um novo projeto de lei. Rio de Janeiro: Centro Positivista, 1893.

LEMOS, Miguel. O projecto de casamento civil carta a s. ex. o sr. Ministro do império. Rio de Janeiro: Centro Positivista, 1887.

LEVI-STRAUSS, Claude. Antropologia estrutural. Tradução: Beatriz Perrone-Moisés. (?): Cosac Naify, 2002.

LEVI-STRAUSS, Claude. As estruturas elementares do parentesco. Tradução: Mariano Ferreira. Petrópolis: Vozes, 1982.

LEVI-STRAUSS, Claude. O pensamento selvagem. Tradução: Tânia Pellegrini. Campinas: Papirus, 1989.

LIMA, Lana Lage da Gama. A Confissão pelo Avesso: o crime de solicitação no Brasil Colonial. 1990. Tese (doutorado) - Faculdade de Filosofia, Letras e Ciências Humanas da Universidade de São Paulo, 1990. v. 2.

LIMA, Maurilio Cesar de. Breve história da Igreja no Brasil. Rio de Janeiro: Restauro, 2001.

LISBOA. (Arquidiocese). Constituições synodaes do Arcebispado de Lisboa...: Concordadas com o sagrado Concilio Tridentino, e com o dereito canonico, e com as constituições antigas e extravagantes primeiras, e segundas deste arcebispado. Lisboa: P. Craesbeeck, 1656. Disponível em http://hdl.handle.net/fcrb/237. Acesso em: 22 nov. 2019. 
LLORCA, Bernadino. Manual de história Eclesiástica. Lisboa: Editorial Labor, [s.d.].

LONDOÑO, Fernando Torres. A outra família: concubinato, igreja e escândalo na colônia. São Paulo: Editora USP; Loyola, 1999. .

LONDOÑO, Fernando Torres. El concubinado y la iglesia em el Brasil Colonial. São Paulo: Centro de Estudos de Demografia Histórica da América Latina, Universidade de São Paulo, Faculdade de Filosofia, Letras e Ciências Humanas, 1988. (Estudos CEDHAL, n. 2).

LORDELLO, Josette Magalhães. Entre o reino de Deus e dos homens: a secularização do casamento no Brasil do século XIX. Brasília: Editora Universidade de Brasília, 2002.

LOTUFO, Renan. Direito civil constitucional. São Paulo: Malheiros, 2002.

LUTERO e a Reforma: 480 anos depois das 95 teses, uma avaliação dos seus aspectos teológicos, filosóficos, políticos, sociais e econômicos. São Paulo: Editora Mackenzie (sério colóquios, v. 1), 2000.

LUTERO, Martinho. Da vida matrimonial. In: Obras Selecionadas: ética: fundamentos, oração, sexualidade, educação, economia. São Leopoldo; Porto Alegre: Sinodal; Concórdia, 1995. v. 5.

MAGALHÃES, Bruno de Almeida. Do casamento religioso no Brasil. Rio de Janeiro: A. Coelho Branco Editor, 1937.

MARCÍLIO, Maria Luiza. Os registros paroquiais e a história do Brasil. Revista Varia História, n. 31, p. 13-20,jan. 2004.

MARIANO, Lydio. Comentario a lei do casamento civil. Rio de Janeiro: Jornal do Brasil: 1898.

MARKY, Thomas. Curso elementar de direito romano, 2. ed.. São Paulo: Resenha Tributária, 1974.

MARTINS JUNIOR, Isidoro. História do direito nacional. Brasília: Departamento de Imprensa Nacional, 1979.

MEIRA, Silvio Romero de Lemos. Teixeira de Freitas: o jurisconsulto do Império. Notas introdutórias de Afonso Arinos de Melo Franco, Gilberto Freyre e Djacir Menezes. Rio de Janeiro: J. Olimpio; Brasília, DF: INL, 1979.

MELO, Francisco Manuel de. Carta de guia de casados, para que pelo caminho da prudência se acerca a casa do descanso. Coimbra: 1747.

MIRANDA, Alina Silva Sousa de. União indissolúvel e perpétua?: modernidade e expressões familiares à época da secularização dos casamentos (1890-1930). 2012. Tese (Doutorado) Faculdade de Filosofia, Letras e Ciências Humanas, Universidade de São Paulo. São Paulo: 2012. 
MONIZ, Salvador. Lei, processo e formulário do casamento civil para uso dos juízes de casamentos. Rio de Janeiro: Imprensa Nacional, 1890.

MONTEIRO, Washington de Barros. Curso de direito civil. 35. ed. São Paulo: Saraiva, 1999

MORAIS, Luísa Cristina de Carvalho. Direito, Estado e Religião. Dissertação (Mestrado) Faculdade de Direito da Universidade Federal de Minas Gerais, Belo Horizonte, 2016.

MOREIRA ALVES, José Carlos. A Contribuição do antigo Direito Português no Código Civil brasileiro. In: CAETANO, Marcello. Estudos de direito civil brasileiro e português (I Jornada Luso-Brasileira de Direito Civil). São Paulo: Revista dos Tribunais, 1980.

MOREIRA ALVES, José Carlos. A natureza jurídica do casamento romano no direito clássico. Disponível em: www.revistas.usp.br/rfdusp/article/download/67287/69897. Acesso em: 11 jul. 2017.

MOREIRA ALVES, José Carlos. Direito romano. 18. ed. rev. Rio de Janeiro: Forense, 2018.

MORGAN, Lewis. A sociedade primitiva. Lisboa, Portugal, [s.d.].

NAZZARI, Muriel. O Desaparecimento do Dote. Mulheres, famílias e mudança social em São Paulo, Brasil, 1600-1900. São Paulo: Editora Schwarcz, 2001

NEDER, Gizlene. Exílio e luto no Brasil oitocentista. Disponível em: http://www.psicopatologiafundamental.org.br/uploads/files/iii_congresso/temas_livres/exil io_e_luto_no_brasil_oitocentista.pdf. Acesso em: 07 jan. 2020.

NÓBREGA, Manuel da. Carta do Brasil. Belo Horizonte: Itatiaia / São Paulo: USP, 1988.

NORONHA, Ibsen. Breves considerações acerca do influxo do Cristianismo sobre o Matrimônio no Direito Romano. Caderno Virtual IDPn ${ }^{\circ}$ 24, v. 1, jul-dez/2011.

NOVINSKY, Anita. Inquisição: prisioneiros do Brasil. Séculos XVI-XVIII. Rio de Janeiro: Expressão e Cultura, 2002.

ORESTANO, Riccardo. La struttura giuridica del matrimonio romano - Dal diritto classico al dirittto giustininaeo. Roma: Universitá Gregoriana Editrice, 1970.

PAUSINI, Adel I. S. C. R. De Estado a Civil: As relações matrimoniais da Casa Imperial do Brasil (1864-1944). Dissertação (Mestrado) - Pontifícia Universidade Católica de São Paulo. São Paulo: 2014.

PEREIRA, Lafayete Rodrigues. Direito de familia. Anotações e adaptações do Código Civil por José Bonifácio de Andrada Silva. Rio de Janeiro: Virgílio Maira \& Comp., 1918.

PEREIRA, Lafayette Rodrigues. Direitos de família. Rio de Janeiro: Garnier, 1869.

PEREIRA, Lafayette Rodrigues. Direitos de família. Rio de Janeiro: Freitas Bastos, 1956. 
PESSOA, Maurício. O casamento no direito civil constitucional. In: VIANA, Rui Geraldo; NERY, Rosa Maria de Andrade (Orgs). Temas atuais de direito civil na Constituição Federal. São Paulo: Ed. Revista dos Tribunais, 2000.

PINTO. Luiz de Aguiar Costa. Lutas de famílias no Brasil. 2. ed. Rio de Janeiro: Ed. Brasiliana, 1980.

PONTES DE MIRANDA, Francisco Cavalcanti. Direito de família. Rio de Janeiro: Jacintho Ribeiro dos Santos Ed., 1917.

PONTES DE MIRANDA, Francisco Cavalcanti. Fontes e evolução do direito civil brasileiro. 2. ed. Rio de Janeiro: Forense, 1981.

PONTES DE MIRANDA, Francisco Cavalcanti. Tratado de direito de família. 3.ed. São Paulo: Max Limonad, 1947.

PORTUGAL. Ordenações Filipinas. Lei de 17 de agosto de 1761 (cont.), Alvará de 17 de agosto de 1761. Disponível em: http://www1.ci.uc.pt/ihti/proj/filipinas/14pa1033.htm. Acesso em: 02 jan. 2020.

POVEDA VELASCO, Ignacio Maria. Os esponsais no direito luso-brasileiro. São Paulo: Quartier Latin, 2007.

PROMULGAÇÃO da lei sobre o casamento civil Decreto n. 181. Rio de Janeiro: Imprensa Nacional, 1890.

REGIMENTO do Auditório Ecclesiastico do Arcebispado da Bahia. São Paulo: Typographia 2 de Dezembro de Antonio Louzada Antunes, 1853.

REX, Richard. Henry VIII and the English Refomation. Kindle Edition, 2006.

REYCEND, João Baptista. O sacrosanto e ecumenico Concilio de Trento em Latim e Portuguez. Lisboa: OfficinaPatriarc. de Francisco Luiz Ameno, 1781. t.1 e t. 2.

RODRIGUES, Silvio. Direito civil: direito de família. Atualizado por Francisco José Cahali. 27. ed. São Paulo: Saraiva 2002.

ROLIM, Luiz Antonio. Instituições de direito romano. 2. ed. São Paulo: Ed. Revista dos Tribunais, 2003.

ROMERO, Sylvio. Ensaio de philosophia do direito. 2. ed. Rio de Janeiro: 1908.

ROUSSEAU, Jean-Jacques. Do contrato social: princípios do direito político. São Paulo: Editora CID, 2005.

SAINT-HILAIRE, Auguste de. Segunda viagem a São Paulo e Quaro histórico da Província de São Paulo. São Paulo: 1953.

SAINT-HILAIRE, Auguste de. Viagem à província de São Paulo e Resumo das viagens ao Brasil, Província Cisplatina e Missões do Paraguai. São Paulo: 1972. 
SAINT-HILAIRE, Auguste de. Viagem pelas Províncias do Rio de Janeiro e Minas Gerais. Belo Horizonte: Itatiaia; São Paulo: Edusp, 1975.

SALVADOR, frei Vicente do. História do Brasil. Belo Horizonte: Itatiaia; São Paulo: Edusp, 1982.

SAMARA, Eni de Mesquita. Casamento e papéis familiares em São Paulo no séc. XIX. Revista de Estudos e Pesquisas em Educação, n. 37, p. 17-25, maio 1981.

SANT'ANNA, Nuto. Metrópole (histórias da cidade de São Paulo, também chamada São Paulo de Piratininga e São Paulo do Campo em temos de El-Rei, o Cardeal Dom Henrique, da Dinastia de Avis). São Paulo: Departamento de Cultura, 1953. v. 3.

SANTIROCCHI, Ítalo. O matrimônio no Império do Brasil: uma questão de Estado. Revista Brasileira de História das Religiões, ANPUH, ano 4, n. 12, jan. 2012.

SANTOS, Giovanna Aparecida Schittini. Direito e gênero: Rui Gonçalves e o estatuto jurídico das mulheres em Portugal na transição para a Idade Moderna Dissertação (Mestrado) - Faculdade de Ciências Humanas e Filosofia da Universidade Federal de Goiás. Goiânia, 2007. Disponível em https://pos.historia.ufg.br/up/113/o/Giovanna_Santos.pdf. Acesso em: 05 jan. 202.

SANTOS, Severino Augusto dos. "Iustae Nuptiae Vel Matrimonium”: Direito Romano, Cristianismo e Reflexos sobre o Direito Civil Brasileiro. Tese de Doutorado apresentada à Faculdade de Direito da Universidade de Coimbra. Coimbra: 2015.

SCHILLEBEECKX, E. O matrimônio, realidade terrestre e mistério de salvação. Petrópolis: Vozes, 1969.

SEABRA, Campos. Estudo medico-legal do casamento: motivos de impedimentos e de nulidade de casamento e motivos de divorcio. Rio de Janeiro: s. n., 1902.

SESBOÜÉ, Bernard. O matrimônio. In: História dos dogmas. São Paulo: Edições Loyola, São Paulo, 2005. t. 3.

SILVA, Amélia M P. da. Recepção do Concílio de Trento em Portugal: as normas enviadas pelo Cardeal D. Henrique ao Bispo do Reino, em 1553. Revista da Faculdade de Letras. Disponível em: http://aleph.letras.ip.pt/F?func==find_code=SYS7request $=00189225$. Acesso em: 25 maio 2017.

SILVA, Carolina G. "Até que a morte os separe": casamento reformado nos séculos XI-XII. Dissertação (Mestrado). Faculdade de Filosofia, Letras e Ciências Humanas. Universidade de São Paulo. São Paulo: 2008.

SILVA, Isabella Alves. Casamento misto no Bispado do Maranhão (1863-1886). 2016. Dissertação (Mestrado) - Programa de Pós Graduação em História da Universidade Federal do Maranhão, 2016. 
SILVA, Isabella Alves. Casamento misto no Bispado do Maranhão (1863-1886). 2016. Dissertação (Mestrado) - Programa de Pós-Graduação em História da Universidade Federal do Maranhão, 2016.

SILVA, José Justino de Andrade e. Coleção cronológica da legislação portuguesa compilada e anotada por (...) (1634-1640). Lisboa: 1855.

SILVA, José Justino de Andrade e. Coleção cronológica da legislação portuguesa compilada e anotada por (...) (1648-1656). Lisboa: 1856.

SILVA, José Justino de Andrade e. Coleção cronológica da legislação portuguesa compilada e anotada por (...) (1683-1700). Lisboa: 1859.

SILVA, José Luiz Mônaco da. O casamento, o regime de bens à luz do direito comparado e o novo regime de participação final nos aquestos. 2006. Tese (Doutorado em Direito) Pontifícia Universidade Católica de São Paulo, São Paulo, 2006.

SILVA, Manuel Tavares da. Manual ecclesiastico. 2. ed. São Luiz: Casa Ramos D'Almeida Editor, 1870.

SILVA, Maria Beatriz Nizza da. A Legislação Pombalina e a Estrutura da família no Antigo Regime Português.In: Pombal Revisitado - Comunicações ao Colóquio Internacional Organizado pela Comissão de Comemoração do $2^{\circ}$ Centenário da Morte do Marquês de Pombal I. Lisboa: Estampa, 1984.

SILVA, Maria Beatriz Nizza da. O divórcio na Capitania de São Paulo: Vivência, História, sexualidade e imagens femininas. São Paulo: 1980.

SILVA, Maria Beatriz Nizza da. Sistema de Casamento no Brasil Colonial. São Paulo: Editora da Universidade de São Paulo, 1984.

SILVA, Maria da Conceição. Catolicismo e casamento civil na Cidade de Goiás: conflitos políticos e religiosos (1860 - 1920). Revista Brasileira de História, v. 23, n. 46, p. 123-146, jan. 2003.

SILVA, Nuno Espinosa Gomes da. História do casamento em Portugal. Lisboa: Universidade Católica Editora, 2013.

SILVA, Nuno Espinosa Gomes da. História do direito português - fontes de direito. 2. ed. Lisboa: Fundação Calouste Gulbenkian, 1991.

SIMÃO, José Fernando; TARTUCE, Flávio. Direito civil - direito de família. 3. ed. São Paulo: Método, 2008. v. 3.

SIQUEIRA, Sônia. A disciplina da vida colonial: os Regimentos da Inquisição. Revista do Instituto Histórico e Geográfico Brasileiro, Rio de Janeiro, n. 392, 1996.

SOARES, Oscar Macedo. Casamento civil: Decreto n. 181 de 24 de janeiro de 1890 commentado. Rio de Janeiro; Paris: H. Garnier Livreiro Editor, 1905. 
SOUSA, Alina Silva. A família na república: imprensa e casamento civil em São Luis na década de 1890. Dissertação (Mestrado) Faculdade de Filosofia, Letras e Ciências Humanas da Universidade de São Paulo. São Paulo: 2008.

SOUZA, Braz Florentino Henriques de. O casamento civil e o casamento religioso. Recife: Typographia Academica de Miranda e Vasconcellos, 1859.

STONE, Lawrence. The Family, sex and marriage in England. 1500-1800. Abridged Edition. Harmondsworth, Middlesex, England: Penguin Books, 1979.

TAUNAY, Alfredo d'Escragnolle. Casamento civil. Rio de Janeiro: Imprensa Nacional, 1886.

TEIXEIRA DE FREITAS, Augusto. Consolidações das leis civis. Ed. fac símile - Brasília, DF: Senado Federal, Conselho Editorial, 2003. V. 1,

TOMASEVICIUS FILHO, Eduardo. Breves notas às cartas de José de Anchiet”. Revista da Faculdade de Direito, Universidade de São Paulo, São Paulo, v. 99, p. 557-569, 2004.

TORRES NETO, José Lourenço. Teixeira de Freitas: codificação, casamento civil e escravidão na retórica do direito no fim do Segundo Império. Dissertação (Mestrado) Universidade Federal de Pernambuco. Recife: 2014.

TOTVARAD, Carlos Kornis de. Casamento civil, ou, o direito do poder temporal em negocios de casamento discussão jurídico-historico-theologica. Rio de Janeiro: Laemmert, 1858.

TOTVÁRAD, Carlos Kornis de. Refutação da doutrina do dr. Braz Florentino Henriques de Souza: apresentada na sua obra o casamento civil e religioso. Rio de Janeiro: Livr. Universal de E \& H. Laemmert, 1860. Disponível em: https://www2.senado.leg.br/bdsf/handle/id/242754. Acesso em: 28 nov. 2019.

TRUGILHO, Michelle. Transgressores do matrimônio: a bigamia através da ótica inquisitorial. Disponível em:

VAINFAS, Ronaldo. (Coord.). História e sexualidade no Brasil. Rio de Janeiro: Graal,1986.

VAINFAS, Ronaldo. (Org.). Dicionário do Brasil colonial (1500/1808). Rio de Janeiro: Objetiva, 2001.

VAINFAS, Ronaldo. Casamento, amor e desejo no ocidente cristão. 2. ed. São Paulo: Ática, 1992.

VAINFAS, Ronaldo. Trópico dos pecados: moral, sexualidade e Inquisição no Brasil. Rio de Janeiro: Nova Fronteira, 1997.

VALLS, Rafael Navarro. “Matrimonio y derecho". Madrid: Editorial Tecnons, 1995. 
VIDE, Dom Sebastião Monteiro de. Constituições Primeiras do Arcebispado da Bahia (1707). Brasília, DF: Senado Federal, 2007. Disponível em: http://www2.senado.leg.br/bdsf/item/id/222291. Acesso em: 20/11/2016.

VIDIGAL, Afrodísio. Repertorio ou índice alfabético da lei do casamento civil. São Paulo: King, 1890.

VIEIRA, David Gueiros. O liberalismo, a maçonaria e o protestantismo no Brasil do Século XIX. Estudos Teológicos, v. 27, n. 3, p. 203, 1987. Disponível em: http://periodicos.est.edu.br/index.php/estudos_teologicos/article/viewArticle/1216. Acesso em: 20 out. 2019.

VIEIRA, Dilermando Ramos. O processo de reforma e reorganização da Igreja no Brasil (1844-1926). Aparecida: Santuário, 2007.

VILLALTA, Luiz Carlos (Org. e sel.). Carta do Padre Manoel da Nóbrega ao padre Mestre Simão, 1549 e Sentença do Juízo eclesiástico de Mariana. In: Coletânea de documentos e textos. Belo Horizonte, 2003.

VITERBO, Joaquim de Santa Rosa de. Elucidário das palavras, termos e frases que em Portugal antigamente se usaram e que hoje regularmente se ignoram: obra indispensável para entender sem erro os documentos mais raros e preciosos que entre nós se conservam / Publicado em beneficio da litheratura portugueza por Fr. Joaquim de Santa Rosa Viterbo. .... 2. ed. revista, correcta e copiosamente addicionada de novos vocábulos, observações e notas críticas com um índice remissivo. Lisboa: A. J. Fernandes Lopes, 1865. 2 v. Disponível em: http://purl.pt/13944. Acesso em: 20 nov. 2019.

WALD, Arnoldo. Curso de direito civil brasileiro: o novo direito de família. 12. ed. São Paulo: Revista dos Tribunais, 1999.

WESTERMARCK, Edward. Historia del matrimonio. Madrid: Laertes, 1984.

WICKLER, Wolfgang. As leis naturais do casamento. Trad. Lia Tavares. Sintra: Publicações Europa-América, 1976. 


\section{ANEXO I \\ Esquema de graus de parentesco pelo Direito Canônico e pelo Direito Civil}

Fonte: MACEDO SOARES, Oscar. Casamento Civil: decreto n. 181 de 24 de Janeiro de 1890 commentado. Rio de Janeiro - Paris: H. Garnier Livreiro Editor, 1905, p. 18-20, elaborada com base na doutrina de BORGES CARNEIRO, Manuel. Direito civil de Portugal, $\S 161$.

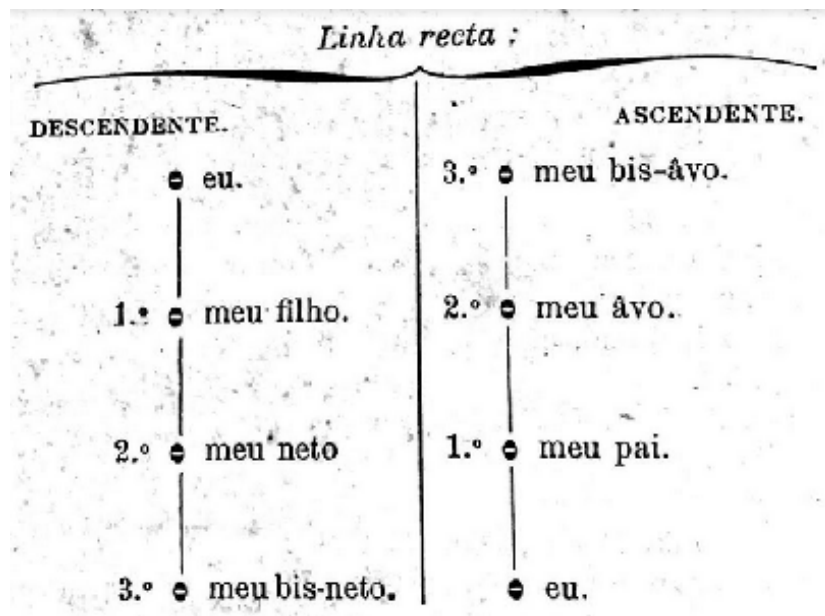

Linha ascendente: Meu pai é meu parente em $1^{\circ}$ grau, meu avô em $2^{\circ}$ e meu bisavô em $3^{\circ}$.

Linha descendente: Meu filho é meu parente em $1^{\circ}$ grau, meu neto em $2^{\circ}$ e meu bisneto em $3^{\circ}$.

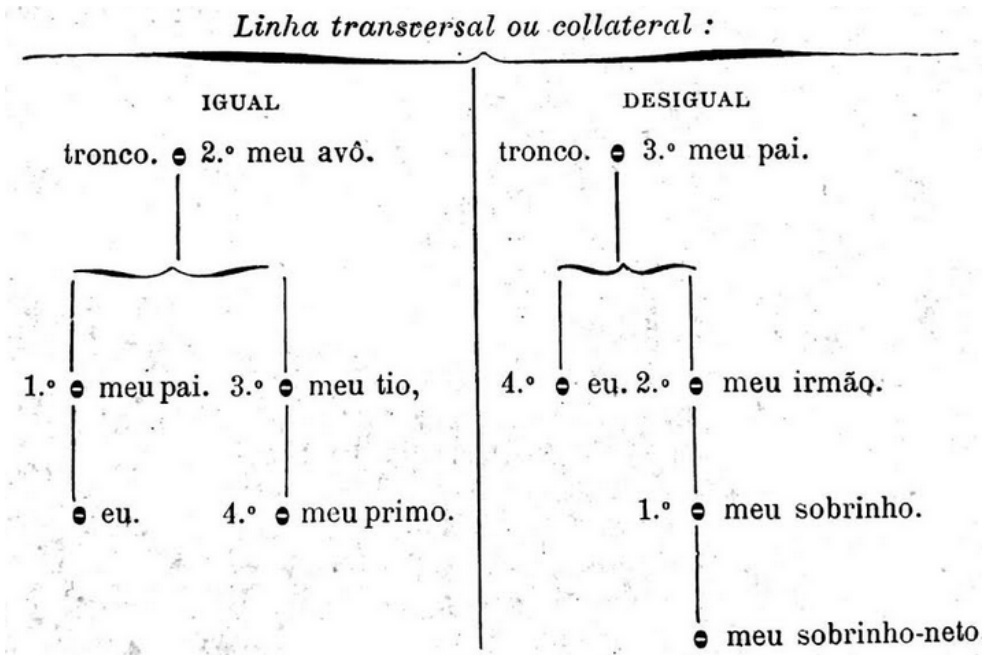

Linha colateral igual: Eu estou com meu primo, filho do meu tio (meu primo-irmão) no $4^{\circ}$ grau, com meu tio no $3^{\circ}$. Isto por direito civil. Pelo direito canônico eu estou com meu primo-irmão no $3^{\circ}$ grau, com meu tio no $2^{\circ}$.

Linha colateral desigual: Eu estou com meu sobrinho-neto no $4^{\circ}$ grau, com meu sobrinho no $3^{\circ}$, com meu irmão no $2^{\circ}$. Isto pelo direito civil, notando-se que nas linhas desiguais atende-se a mais remota 
e diz-se que são parentes no grau em que o mais remoto dista do tronco. Pelo direito canônico eu estou com meu sobrinho-neto no $3^{\circ}$ grau, com meu sobrinho no $2^{\circ}$ e com meu irmão no $1^{o}$.

Note-se ainda pelos esquemas e segundo a numeração: Na linha colateral igual começo por mim a contar os grãos, subo até meu avô e desço na linha paralela até meu primo-irmão.

Na linha colateral desigual começo por meu sobrinho-neto, subo até meu pai e desço até mim em linha paralela.

“A afinidade é a relação que liga um dos cônjuges aos parentes do outro. Em rigor na afinidade não se podem contar grãos; porém por analogia segue-se a regra de que uma pessoa é afim dos parentes do seu cônjuge no mesmo grau, em que este o é pela consanguinidade. A afinidade também resulta do ajuntamento ilícito para alguns efeitos."

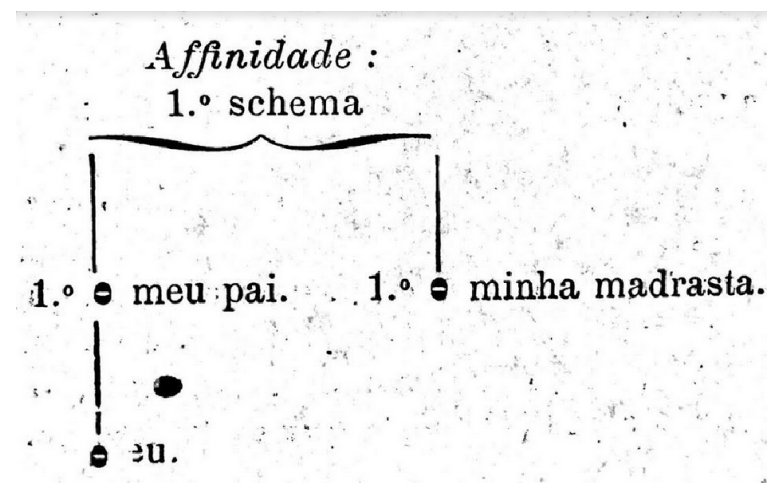

$\mathrm{Eu}$ estou no $1^{\circ}$ grau de afinidade em linha reta com minha madrasta, porque estou em $1^{\circ}$ grau com meu pai.

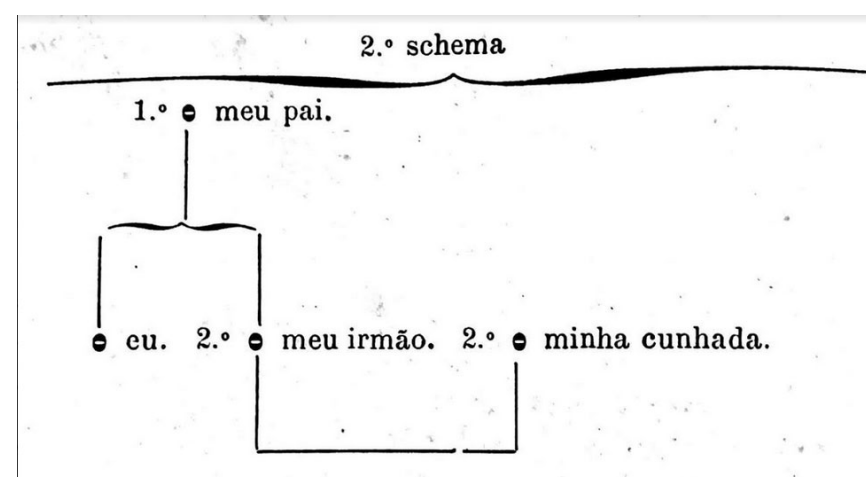

Eu estou com minha cunhada no $1^{\circ}$ grau por direito canônico, no $2^{\circ}$ por direito civil. 


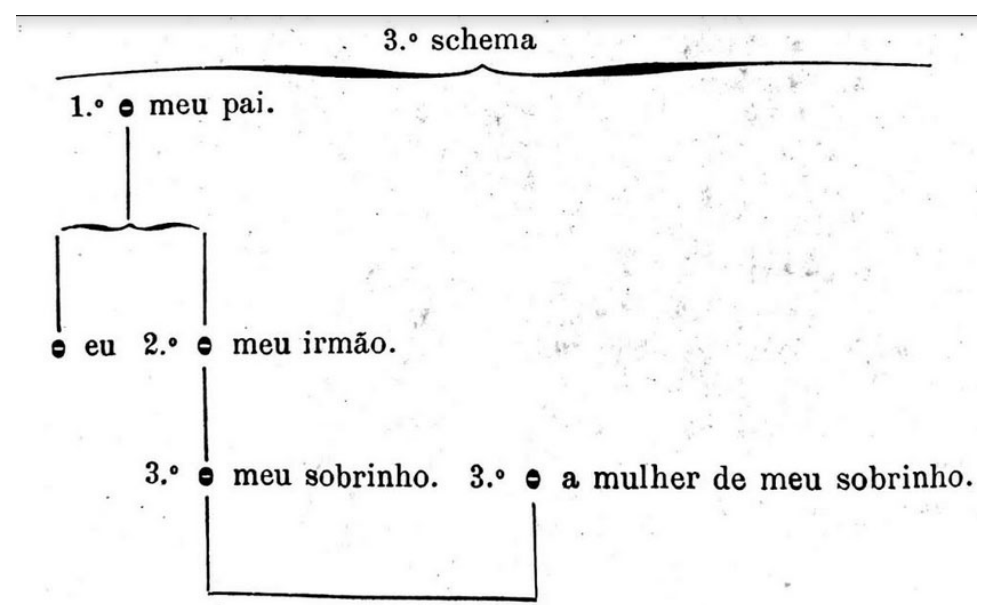

Por direito canônico eu estou com a mulher do meu sobrinho no $2^{\circ}$ grau, e no $3^{\circ}$ por direito civil. 
ANEXO II

\section{Quadro comparativo: principais legislações sobre casamento civil no Brasil (Decreto n ${ }^{0} 181$ de 1890, Código Civil de 1916 e Código Civil de 2002 )}

\begin{tabular}{|c|c|c|}
\hline Decreto $n^{0} 181$ de 1890 & Código Civil de 1916 & Código Civil de 2002 \\
\hline $\begin{array}{l}\text { Art. } 1^{\circ} \text { As pessoas, que } \\
\text { pretenderem casar-se, devem } \\
\text { habilitar-se perante o official } \\
\text { do registro civil, exhibindo os } \\
\text { seguintes documentos em } \\
\text { fórma, que lhes deem fé } \\
\text { publica: } \\
\S 1^{\circ} \text { A certidão da idade de } \\
\text { cada um dos contrahentes, ou } \\
\text { prova que a suppra. } \\
\S 2^{\circ} \text { A declaração do estado e } \\
\text { da residencia de cada um } \\
\text { delles, assim como a do estado } \\
\text { e residencia de seus paes, ou } \\
\text { do logar em que morreram, si } \\
\text { forem fallecidos, ou a } \\
\text { declaração do motivo por que } \\
\text { não são conhecidos os mesmos } \\
\text { paes, ou o seu estado e } \\
\text { residencia, ou o logar do seu } \\
\text { fallecimento. } \\
\S 3^{\circ} \text { A autorização das } \\
\text { pessoas, de cujo } \\
\text { consentimento dependerem os } \\
\text { contrahentes para casar-se, si } \\
\text { forem menores ou interdictos. } \\
\S 4^{\circ} \text { A declaração de duas } \\
\text { testemunhas, maiores, parentes } \\
\text { ou estranhos, que attestem } \\
\text { conhecer ambos os } \\
\text { contrahentes, e que não são } \\
\text { parentes em gráo prohibido } \\
\text { nem teem outro impedimento, } \\
\text { conhecido, que os inhiba de } \\
\text { casar-se um com o outro. } \\
\S 5^{\circ} \text { A certidão de obito do } \\
\text { conjuge fallecido, ou da } \\
\text { annullação do anterior } \\
\text { casamento, si algum dos } \\
\text { nubentes o houver contrahido. }\end{array}$ & $\begin{array}{l}\text { Art. 180. A habilitação para } \\
\text { casamento faz-se perante o } \\
\text { oficial do registro civil, } \\
\text { apresentando-se os seguintes } \\
\text { documentos: } \\
\text { I. Certidão de idade ou prova } \\
\text { equivalente. } \\
\text { II. Declaração do estado, do } \\
\text { domicílio e da residência atual } \\
\text { dos contraentes e de seus pais, } \\
\text { se forem conhecidos. } \\
\text { III. Autorização das pessoas } \\
\text { sob cuja dependência legal } \\
\text { estiverem, ou ato judicial que } \\
\text { a supra (arts. 183, n. XI, } 188 \text { e } \\
\text { 196). } \\
\text { IV. Declaração de duas } \\
\text { testemunhas maiores, } \\
\text { parentes, ou estranhos, que } \\
\text { atestem conhecê-los e } \\
\text { afirmem não existir } \\
\text { impedimento, que os iniba de } \\
\text { casar. } \\
\text { V. Certidão de óbito do } \\
\text { cônjuge falecido ou da } \\
\text { anulação do casamento } \\
\text { anterior. } \\
\text { V - certidão de óbito do } \\
\text { cônjuge falecido, da anulação } \\
\text { do casamento anterior ou do } \\
\text { registro da sentença de } \\
\text { divórcio. } \\
\text { (Redação dada pela Lei no } \\
\text { 6.515, de 1977). } \\
\end{array}$ & $\begin{array}{l}\text { Art. 1.525. O requerimento de } \\
\text { habilitação para o casamento } \\
\text { será firmado por ambos os } \\
\text { nubentes, de próprio punho, ou, } \\
\text { a seu pedido, por procurador, e } \\
\text { deve ser instruído com os } \\
\text { seguintes documentos: } \\
\text { I - certidão de nascimento ou } \\
\text { documento equivalente; } \\
\text { II - autorização por escrito das } \\
\text { pessoas sob cuja dependência } \\
\text { legal estiverem, ou ato judicial } \\
\text { que a supra; } \\
\text { III - declaração de duas } \\
\text { testemunhas maiores, parentes } \\
\text { ou não, que atestem conhecê-los } \\
\text { e afirmem não existir } \\
\text { impedimento que os iniba de } \\
\text { casar; } \\
\text { IV - declaração do estado civil, } \\
\text { do domicílio e da residência } \\
\text { atual dos contraentes e de seus } \\
\text { pais, se forem conhecidos; } \\
\text { V - certidão de óbito do cônjuge } \\
\text { falecido, de sentença } \\
\text { declaratória de nulidade ou de } \\
\text { anulação de casamento, } \\
\text { transitada em julgado, ou do } \\
\text { registro da sentença de divórcio. }\end{array}$ \\
\hline
\end{tabular}




\begin{tabular}{|c|c|c|}
\hline $\begin{array}{l}\text { Art. } 2^{\circ} \text { À vista dos } \\
\text { documentos exigidos no artigo } \\
\text { antecedente, exhibidos pelos } \\
\text { contrahentes, ou por seus } \\
\text { procuradores, ou } \\
\text { representantes legaes, o } \\
\text { official do registro redigirá um } \\
\text { acto resumido em fórma de } \\
\text { edital, que será por elle } \\
\text { publicado duas vezes, com o } \\
\text { intervallo de sete dias de uma } \\
\text { á outra, e affixado em logar } \\
\text { ostensivo no edificio da } \\
\text { repartição do registro, desde a } \\
\text { primeira publicação até ao } \\
\text { quinto dia depois da segunda. }\end{array}$ & $\begin{array}{l}\text { Art. 181. À vista desses } \\
\text { documentos apresentados } \\
\text { pelos pretendentes, ou seus } \\
\text { procuradores, o oficial do } \\
\text { registro lavrará os proclamas } \\
\text { de casamento, mediante edital, } \\
\text { que se afixará durante quinze } \\
\text { dias, em lugar ostensivo do } \\
\text { edifício, onde se celebrarem } \\
\text { os casamentos, e se publicará } \\
\text { pela imprensa, onde a houver } \\
\text { (art. 182, parágrafo único). }\end{array}$ & $\begin{array}{l}\text { Art. 1.527. Estando em ordem a } \\
\text { documentação, o oficial extrairá } \\
\text { o edital, que se afixará durante } \\
\text { quinze dias nas circunscrições } \\
\text { do Registro Civil de ambos os } \\
\text { nubentes, e, obrigatoriamente, } \\
\text { se publicará na imprensa local, } \\
\text { se houver. } \\
\text { Parágrafo único. A autoridade } \\
\text { competente, havendo urgência, } \\
\text { poderá dispensar a publicação. }\end{array}$ \\
\hline $\begin{array}{l}\text { Art. } 3^{\circ} \mathrm{Si} \text {, decorrido este } \\
\text { prazo, não tiver apparecido } \\
\text { quem se opponha ao } \\
\text { casamento dos contrahentes e } \\
\text { não lhe constar algum dos } \\
\text { impedimentos que elle pode } \\
\text { declarar ex-officio, o official } \\
\text { do registro certificará ás partes } \\
\text { que estão habilitadas para } \\
\text { casar-se dentro dos dous } \\
\text { mezes seguintes áquelle prazo. }\end{array}$ & $\begin{array}{l}\text { Art. } 181, \S 1^{\circ} \mathrm{Se} \text {, decorrido } \\
\text { esse prazo, não aparecer quem } \\
\text { oponha impedimento, nem lhe } \\
\text { constar algum dos que de } \\
\text { ofício lhe cumpre declarar, o } \\
\text { oficial do registro certificará } \\
\text { aos pretendentes que estão } \\
\text { habilitados para casar dentro } \\
\text { nos três meses imediatos (art. } \\
\text { 192). }\end{array}$ & $\begin{array}{l}\text { Art. 1.531. Cumpridas as } \\
\text { formalidades dos arts. } 1.526 \mathrm{e} \\
1.527 \text { e verificada a inexistência } \\
\text { de fato obstativo, o oficial do } \\
\text { registro extrairá o certificado de } \\
\text { habilitação }\end{array}$ \\
\hline $\begin{array}{l}\text { Art. } 4^{\circ} \mathrm{Si} \text { os contrahentes } \\
\text { residirem em diversas } \\
\text { circumscripções do registro } \\
\text { civil, uma cópia do edital será } \\
\text { remettida ao official do outro } \\
\text { districto, que deverá publical-a } \\
\text { e affixal-a na fórma do art. } 2^{\circ} \text {, } \\
\text { e, findo o prazo, certificar si } \\
\text { foi ou não posto impedimento. }\end{array}$ & $\begin{array}{l}\text { Art. } 181, \S 2^{\circ} \text { Se os nubentes } \\
\text { residirem em diversas } \\
\text { circunscrições do registro } \\
\text { civil, em uma e em outra se } \\
\text { publicarão os editais. }\end{array}$ & Vide Art. 1527 acima \\
\hline $\begin{array}{l}\text { Art. } 5^{\circ} \text { Si algum dos } \\
\text { contrahentes houver residido a } \\
\text { mór parte do ultimo anno em } \\
\text { outro Estado, deverá provar } \\
\text { que sahiu delle sem } \\
\text { impedimento para casar-se ou, } \\
\text { si tinha impedimento, que este } \\
\text { já cessou. }\end{array}$ & $\begin{array}{l}\text { Art. 180, Parágrafo único. Se } \\
\text { algum dos contraentes houver } \\
\text { residido a maior parte do } \\
\text { último ano em outro Estado, } \\
\text { apresentará prova de que o } \\
\text { deixou sem impedimento para } \\
\text { casar, ou de que cessou o } \\
\text { existente. }\end{array}$ & \\
\hline $\begin{array}{l}\text { Art. } 6^{\circ} \text { Os editaes dos } \\
\text { proclamas serão registrados no } \\
\text { cartorio do official, que os } \\
\text { tiver publicado e que deverá } \\
\text { dar certidão delles a quem lh'a } \\
\text { pedir. }\end{array}$ & & \\
\hline
\end{tabular}




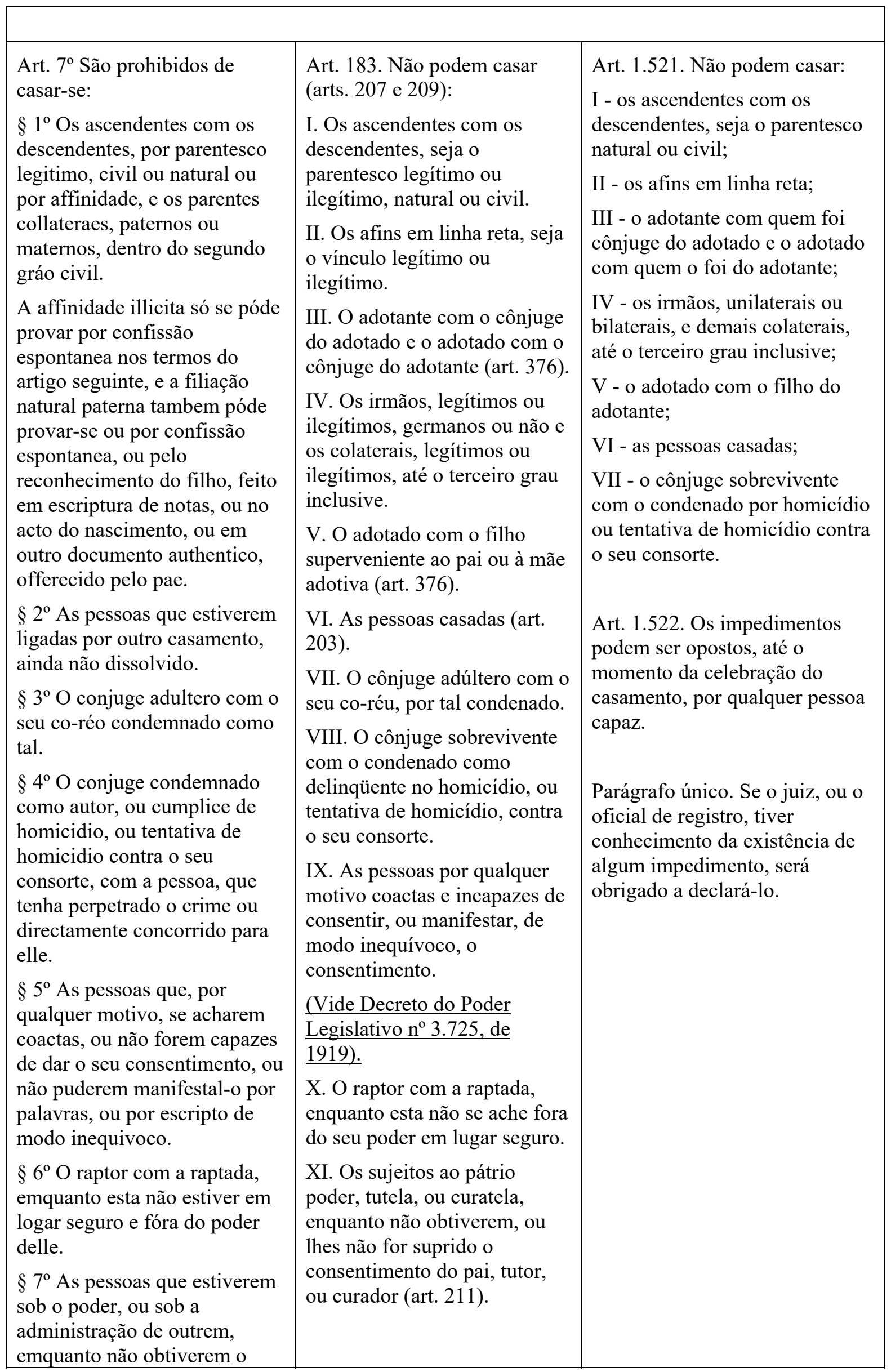


consentimento, ou o supprimento do consentimento daquellas, sob cujo poder ou administração estiverem.

$\S 8^{\circ}$ As mulheres menores de 14 annos e os homens menores de 16.

$\S 9^{\circ} \mathrm{O}$ viuvo ou a viuva, que tem filho do conjuge fallecido, emquanto não fizer inventario dos bens do casal.

$\S 10$. A mulher viuva, ou separada do marido por nullidade ou annullação do casamento, até 10 mezes depois da viuvez ou separação judicial dos corpos, salvo si depois desta, ou daquella, e antes do referido prazo, tiver algum filho.

$\S 11$. O tutor ou o curador e seus descendentes, ascendentes, irmãos, cunhados, ou sobrinhos com a pessoa tutelada, ou curatelada, emquanto não cessar a tutela, ou curadoria, e não estiverem soldadas as respectivas contas, salvo permissão deixada em testamento, ou outro instrumento publico, pelo fallecido pae ou mãe do menor tutelado, ou curatelado.

$\S 12$. O juiz, ou o escrivão e seus descendentes, ascendentes, irmãos, cunhados, ou sobrinhos, com orphão ou viuva da circumscripção territorial, onde um ou outro tiver exercicio, salvo licença especial do presidente da Relação do respectivo districto.

(Vide Decreto do Poder Legislativo $\mathrm{n}^{\circ} 3.725$, de 1919).

XII. As mulheres menores de dezesseis anos e os homens menores de dezoito.

XIII. O viúvo ou a viúva que tiver filho do cônjuge falecido, enquanto não fizer inventário dos bens do casal (art. 226).

(Vide Decreto do Poder Legislativo $\mathrm{n}^{\circ} 3.725$, de 1919).

XIV. A mulher viúva ou separada do marido por nulidade ou anulação do casamento, até dez meses depois da viuvez ou da separação judicial dos corpos, salvo se, antes de terminado o referido prazo, der à luz algum filho.

XIV. A viuva, ou a mulher cujo casamento se desfez por ser nullo ou ter sido annullado, até dez mezes depois do começo da viuvez, ou da dissolução da sociedade conjugal, salvo se antes de findo esse prazo dér á luz algum filho.

(Redação dada pelo Decreto do Poder Legislativo $\mathrm{n}^{\mathrm{o}} 3.725$, de 1919).

$\mathrm{XV}$. O tutor ou curador e os seus descendentes, ascendentes, irmãos, cunhados ou sobrinhos, com a pessoa tutelada ou curatelada, enquanto não cessar a tutela ou curatela, e não estiverem saldadas as respectivas contas, salvo permissão paterna ou materna manifestada em escrito autêntico ou em testamento.

XVI. O juiz, ou escrivão e seus descendentes, ascendentes, irmãos, cunhados ou sobrinhos, com órfão ou 


\begin{tabular}{|c|c|c|}
\hline & $\begin{array}{l}\text { viúva, da circunscrição } \\
\text { territorial onde um ou outro } \\
\text { tiver exercício, salvo licença } \\
\text { especial da autoridade } \\
\text { judiciária superior. }\end{array}$ & \\
\hline $\begin{array}{l}\text { Art. } 8^{\circ} \text { A confissão, de que } \\
\text { trata o } \S 1^{\circ} \text { do artigo } \\
\text { antecedente, só poderá ser } \\
\text { feita por algum ascendente da } \\
\text { pessoa impedida e, quando } \\
\text { elle não quizer dar-lhe outro } \\
\text { effeito, poderá fazel-o em } \\
\text { segredo de justiça, por termo } \\
\text { lavrado pelo official do } \\
\text { registro perante duas } \\
\text { testemunhas e em presença do } \\
\text { juiz, que no caso de recurso } \\
\text { procederá de accordo com o } \S \\
5^{\circ} \text { da lei de } 6 \text { de outubro de } \\
1784, \text { na parte que lhe for } \\
\text { applicavel. } \\
\text { Paragrapho unico. O } \\
\text { parentesco civil prova-se pela } \\
\text { carta de adopção, e o legitimo, } \\
\text { quando não for notorio ou } \\
\text { confessado, pelo acto do } \\
\text { nascimento dos contrahentes, } \\
\text { ou pelo do casamento dos seus } \\
\text { ascendentes. }\end{array}$ & $\begin{array}{l}\text { Art. 184. A afinidade } \\
\text { resultante de filiação espúria } \\
\text { poderá provar-se por } \\
\text { confissão espontânea dos } \\
\text { ascendentes da pessoa } \\
\text { impedida, os quais, se o } \\
\text { quiserem, terão o direito de } \\
\text { fazê-la em segredo de justiça. } \\
\text { Parágrafo único. A resultante } \\
\text { da filiação natural poderá ser } \\
\text { também provada por confissão } \\
\text { espontânea dos ascendentes, } \\
\text { se da filiação não existir a } \\
\text { prova prescrita no art. } 357 .\end{array}$ & \\
\hline $\begin{array}{l}\text { Art. } 9^{\circ} \text { Cada um dos } \\
\text { impedimentos dos } \S \S 1^{\circ} \text { a } 8^{\circ} \\
\text { do art. } 7^{\circ} \text { póde ser opposto ex- } \\
\text { officio pelo official do registro } \\
\text { civil, ou pela autoridade que } \\
\text { presidir ao casamento, ou por } \\
\text { qualquer pessoa, que o } \\
\text { declarar sob sua assignatura, } \\
\text { devidamente reconhecida, com } \\
\text { as provas do facto, que allegar, } \\
\text { ou indicação precisa do logar } \\
\text { onde existam, ou a nomeação } \\
\text { de duas testemunhas, } \\
\text { residentes no logar, que o } \\
\text { saibam de sciencia propria. } \\
\text { Art. } 12 . \text { Os impedimentos dos } \\
\S \S 1^{\circ} \text { a } 6^{\circ} \text { podem ser oppostos } \\
\text { pela autoridade que presidir ao } \\
\text { casamento, no proprio acto da } \\
\text { celebração delle. }\end{array}$ & $\begin{array}{l}\text { Art. 189. Os impedimentos do } \\
\text { art. 183, ns. I a XII podem ser } \\
\text { opostos: } \\
\text { I. Pelo oficial do registro civil } \\
\text { (art. 227, n. III). } \\
\text { II. Por quem presidir à } \\
\text { celebração do casamento. } \\
\text { III. Por qualquer pessoa } \\
\text { maior, que, sob sua assinatura, } \\
\text { apresente declaração escrita, } \\
\text { instruída com as provas do } \\
\text { facto que alegar. } \\
\text { Parágrafo único. Se não puder } \\
\text { instruir a oposição com as } \\
\text { provas, precisara o oponente o } \\
\text { logar, onde existam, ou } \\
\text { nomeará, pelo menos, duas } \\
\text { testemunhas, residentes no } \\
\text { Município, que atestem o } \\
\text { impedimento. }\end{array}$ & $\begin{array}{l}\text { Art. 1.529. Tanto os } \\
\text { impedimentos quanto as causas } \\
\text { suspensivas serão opostos em } \\
\text { declaração escrita e assinada, } \\
\text { instruída com as provas do fato } \\
\text { alegado, ou com a indicação do } \\
\text { lugar onde possam ser obtidas. }\end{array}$ \\
\hline
\end{tabular}




\begin{tabular}{|c|c|c|}
\hline $\begin{array}{l}\text { Art. 10. Si o impedimento for } \\
\text { opposto ex-officio, o official } \\
\text { do registro dará aos nubentes } \\
\text { ou aos seus procuradores uma } \\
\text { declaração do motivo e das } \\
\text { provas do mesmo } \\
\text { impedimento, escripta e } \\
\text { assignada por elle. } \\
\text { Art. 11. Si o impedimento for } \\
\text { opposto por outras pessoas, o } \\
\text { official dará aos nubentes ou } \\
\text { aos seus procuradores uma } \\
\text { declaração do motivo, dos } \\
\text { nomes e das residencias do } \\
\text { impedimento e das suas } \\
\text { testemunhas, e conhecimento } \\
\text { de quaesquer outras provas } \\
\text { offerecidas. }\end{array}$ & $\begin{array}{l}\text { Art. 191. O oficial do registro } \\
\text { civil dará aos nubentes, ou } \\
\text { seus representantes, nota do } \\
\text { impedimento oposto, } \\
\text { indicando os fundamentos, as } \\
\text { provas, e, se o impedimento } \\
\text { não se opôs ex-officio, o } \\
\text { nome do oponente. }\end{array}$ & $\begin{array}{l}\text { Art. } 1.530 \text {. O oficial do registro } \\
\text { dará aos nubentes ou a seus } \\
\text { representantes nota da oposição, } \\
\text { indicando os fundamentos, as } \\
\text { provas e o nome de quem a } \\
\text { ofereceu. }\end{array}$ \\
\hline $\begin{array}{l}\text { Art. 13. No mesmo acto, antes } \\
\text { de proferida a fórmula do } \\
\text { casamento pelos contrahentes, } \\
\text { a mesma autoridade póde } \\
\text { receber qualquer impedimento } \\
\text { legal, cumpridamente provado } \\
\text { e opposto por pessoa } \\
\text { competente. }\end{array}$ & & \\
\hline $\begin{array}{l}\text { Art. } 14 \text {. O impedimento do } \S \\
7^{\circ} \text { tambem poderá ser opposto } \\
\text { pela pessoa de cujo } \\
\text { consentimento depender um } \\
\text { dos contrahentes, ainda que } \\
\text { ella tenha anteriormente } \\
\text { consentido, mas o seu } \\
\text { consentimento póde ser } \\
\text { supprido na fórma da } \\
\text { legislação anterior. }\end{array}$ & & \\
\hline $\begin{array}{l}\text { Art. 15. Os outros } \\
\text { impedimentos só poderão ser } \\
\text { oppostos pelos ascendentes, ou } \\
\text { descendentes, pelos parentes } \\
\text { ou affins dentro do segundo } \\
\text { gráo civil de um dos } \\
\text { contrahentes. }\end{array}$ & $\begin{array}{l}\text { Art. 190. Os outros } \\
\text { impedimentos só poderão ser } \\
\text { opostos: } \\
\text { I. Pelos parentes, em linha } \\
\text { reta, de um dos nubentes, } \\
\text { sejam consangüíneos ou afins. } \\
\text { II. Pelos colaterais, em } \\
\text { segundo grau, sejam } \\
\text { consangüíneos ou afins. }\end{array}$ & \\
\hline $\begin{array}{l}\text { Art. 16. Exceptuados os } \\
\text { impedimentos, cuja prova } \\
\text { especial estiver declarada } \\
\text { nesta lei, todos os mais serão } \\
\text { provados na fórma do } \\
\text { processo civil. }\end{array}$ & & \\
\hline
\end{tabular}




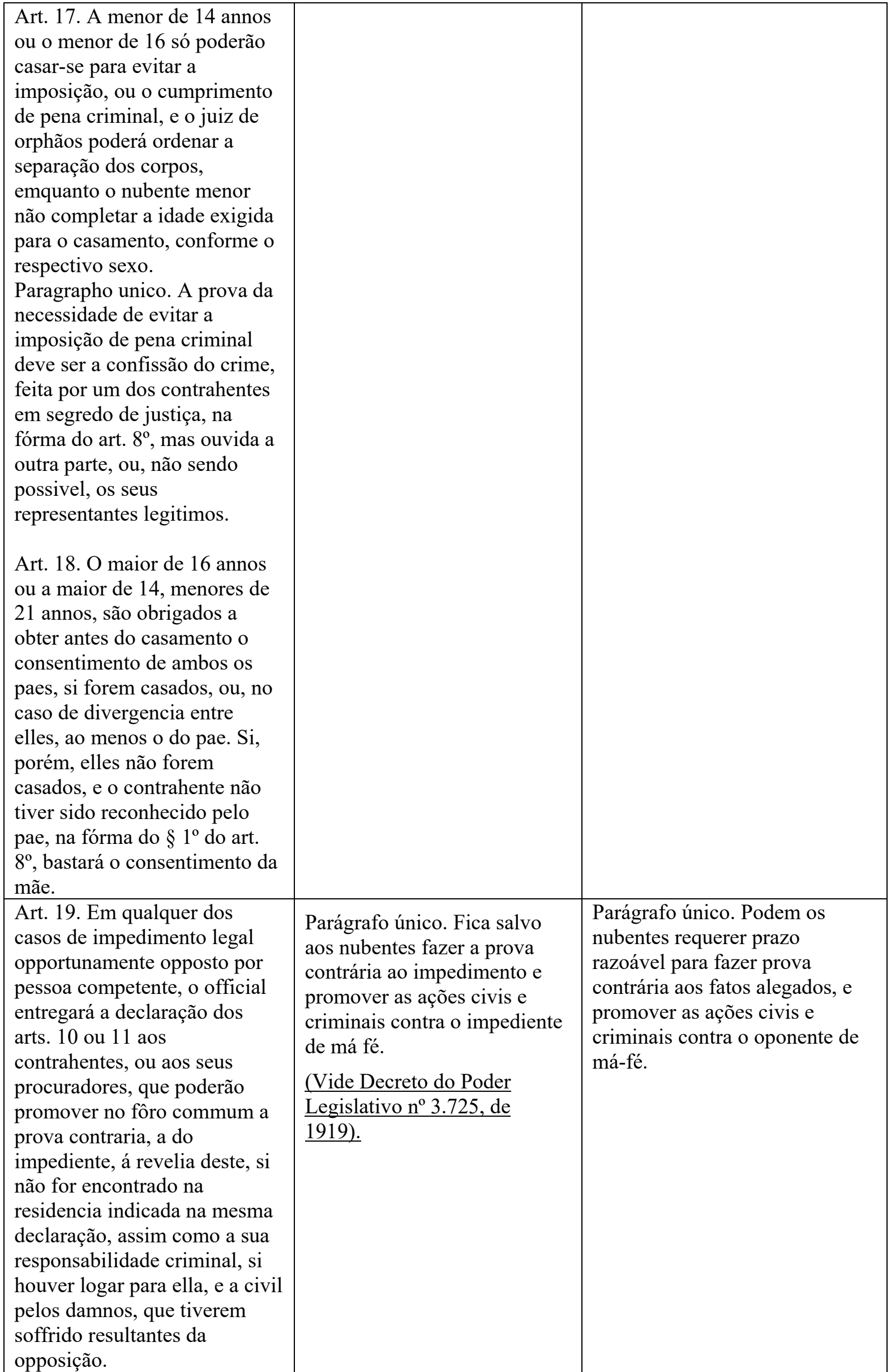




\begin{tabular}{|c|c|c|}
\hline \multicolumn{3}{|c|}{ DA CELEBRAÇÃO DO CASAMENTO } \\
\hline $\begin{array}{l}\text { Art. } 23 \text {. Habilitados os } \\
\text { contrahentes, e com a certidão } \\
\text { do art. } 3^{\circ} \text {, pedirão á } \\
\text { autoridade, que tiver de } \\
\text { presidir ao casamento, a } \\
\text { designação do dia, hora e logar } \\
\text { da celebração do mesmo. }\end{array}$ & $\begin{array}{l}\text { Art. 192. Celebrar-se-á o } \\
\text { casamento no dia, hora e lugar } \\
\text { previamente designados pela } \\
\text { autoridade que houver de } \\
\text { presidir ao ato, mediante } \\
\text { petição dos contraentes, que } \\
\text { se mostrem habilitados com a } \\
\text { certidão do art. } 181, \S 1^{\circ} \text {. }\end{array}$ & $\begin{array}{l}\text { Art. } 1.533 \text {. Celebrar-se-á o } \\
\text { casamento, no dia, hora e lugar } \\
\text { previamente designados pela } \\
\text { autoridade que houver de } \\
\text { presidir o ato, mediante petição } \\
\text { dos contraentes, que se mostrem } \\
\text { habilitados com a certidão do } \\
\text { art. } 1.531 \text {. }\end{array}$ \\
\hline $\begin{array}{l}\text { Art. 24. Na falta de designação } \\
\text { de outro logar, o casamento se } \\
\text { fará na casa das audiencias, } \\
\text { durante o dia e a portas } \\
\text { abertas, na presença, pelo } \\
\text { menos, de duas testemunhas, } \\
\text { que podem ser parentes dos } \\
\text { contrahentes, ou em outra casa } \\
\text { publica ou particular, a } \\
\text { aprazimento das partes, si uma } \\
\text { dellas não puder sahir da sua, } \\
\text { ou não parecer inconveniente } \\
\text { aquella autoridade a } \\
\text { designação do logar desejado } \\
\text { pelos contrahentes. }\end{array}$ & $\begin{array}{l}\text { Art. 193. A solenidade } \\
\text { celebrar-se-á na casa das } \\
\text { audiências, com toda a } \\
\text { publicidade, a portas abertas, } \\
\text { presentes, pelo menos, duas } \\
\text { testemunhas, parentes ou não } \\
\text { dos contraentes, ou, em caso } \\
\text { de força maior, querendo as } \\
\text { partes, e consentindo o juiz, } \\
\text { noutro edifício, público, ou } \\
\text { particular. }\end{array}$ & $\begin{array}{l}\text { Art. 1.534. A solenidade } \\
\text { realizar-se-á na sede do cartório, } \\
\text { com toda publicidade, a portas } \\
\text { abertas, presentes pelo menos } \\
\text { duas testemunhas, parentes ou } \\
\text { não dos contraentes, ou, } \\
\text { querendo as partes e } \\
\text { consentindo a autoridade } \\
\text { celebrante, noutro edifício } \\
\text { público ou particular. }\end{array}$ \\
\hline $\begin{array}{l}\text { Art. 25. Quando o casamento } \\
\text { for feito em casa particular, } \\
\text { esta deverá conservar as portas } \\
\text { abertas, durante o acto, e as } \\
\text { testemunhas serão tres ou } \\
\text { quatro, si um ou ambos os } \\
\text { contrahentes não souberem } \\
\text { escrever. }\end{array}$ & $\begin{array}{l}\text { Art. 193, Parágrafo único. } \\
\text { Quando o casamento for em } \\
\text { casa particular, ficará esta de } \\
\text { portas abertas durante o ato, e, } \\
\text { se algum dos contraentes não } \\
\text { souber escrever, serão quatro } \\
\text { as testemunhas. }\end{array}$ & $\begin{array}{l}\text { Art. } 1534 \S 1^{\circ} \text { Quando o } \\
\text { casamento for em edifício } \\
\text { particular, ficará este de portas } \\
\text { abertas durante o ato. }\end{array}$ \\
\hline $\begin{array}{l}\text { Art. 26. No dia, hora e logar } \\
\text { designados, presentes as } \\
\text { partes, as testemunhas e o } \\
\text { official do registro civil, o } \\
\text { presidente do acto lerá em voz } \\
\text { clara e intelligivel o art. } 7^{\circ} \text { e } \\
\text { depois de perguntar a cada um } \\
\text { dos contrahentes, começando } \\
\text { da mulher, si não tem algum } \\
\text { dos impedimentos do mesmo } \\
\text { artigo, si quer casar-se com o } \\
\text { outro por sua livre e } \\
\text { espontanea vontade, e ter de } \\
\text { ambos resposta affirmativa, } \\
\text { convidal-os-ha a repetirem na } \\
\text { mesma ordem, e cada um de }\end{array}$ & $\begin{array}{l}\text { Art. 26. No dia, hora e logar } \\
\text { designados, presentes as } \\
\text { partes, as testemunhas e o } \\
\text { official do registro civil, o } \\
\text { presidente do acto lerá em voz } \\
\text { clara e intelligivel o art. } 7^{\circ} \text { e } \\
\text { depois de perguntar a cada um } \\
\text { dos contrahentes, começando } \\
\text { da mulher, si não tem algum } \\
\text { dos impedimentos do mesmo } \\
\text { artigo, si quer casar-se com o } \\
\text { outro por sua livre e } \\
\text { espontanea vontade, e ter de } \\
\text { ambos resposta affirmativa, } \\
\text { convidal-os-ha a repetirem na } \\
\text { mesma ordem, e cada um de }\end{array}$ & $\begin{array}{l}\text { Art. } 1.535 \text {. Presentes os } \\
\text { contraentes, em pessoa ou por } \\
\text { procurador especial, juntamente } \\
\text { com as testemunhas e o oficial } \\
\text { do registro, o presidente do ato, } \\
\text { ouvida aos nubentes a afirmação } \\
\text { de que pretendem casar por livre } \\
\text { e espontânea vontade, declarará } \\
\text { efetuado o casamento, nestes } \\
\text { termos:"De acordo com a } \\
\text { vontade que ambos acabais de } \\
\text { afirmar perante mim, de vos } \\
\text { receberdes por marido e mulher, } \\
\text { eu, em nome da lei, vos declaro } \\
\text { casados." }\end{array}$ \\
\hline
\end{tabular}




\begin{tabular}{|c|c|c|}
\hline $\begin{array}{l}\text { per si, a formula legal do } \\
\text { casamento. }\end{array}$ & $\begin{array}{l}\text { per si, a formula legal do } \\
\text { casamento. } \\
\text { De acordo com a vontade que } \\
\text { ambos acabais de afirmar } \\
\text { perante mim, de vos } \\
\text { receberdes por marido e } \\
\text { mulher, eu, em nome da lei, } \\
\text { vos declaro casados.>> }\end{array}$ & \\
\hline $\begin{array}{l}\text { Art. 27. A formula é a seguinte } \\
\text { para a mulher: «Eu F. recebo a } \\
\text { vós F. por meu legitimo } \\
\text { marido, emquanto vivermos.» } \\
\text { E para o homem: «Eu F. } \\
\text { recebo a vós F. por minha } \\
\text { legitima mulher, emquanto } \\
\text { vivermos.» } \\
\text { Art. 28. Repetida a formula } \\
\text { pelo segundo contrahente, o } \\
\text { presidente dirá de pé: «E eu F., } \\
\text { como juiz (tal ou tal), vos } \\
\text { reconheço e declaro } \\
\text { legitimamente casados, desde } \\
\text { este momento.» }\end{array}$ & Vide art. 194 & Vide art. 1535 \\
\hline $\begin{array}{l}\text { Art. 29. Em seguida o official } \\
\text { do registro lançará no } \\
\text { respectivo livro o acto do } \\
\text { casamento nos termos } \\
\text { seguintes, com as } \\
\text { modificações que o caso } \\
\text { exigir: «Aos de de ás horas da } \\
\text { em casa das audiencias do juiz } \\
\text { (ou onde for), presentes o } \\
\text { mesmo juiz commigo official } \\
\text { effectivo (ou ad hoc) e as } \\
\text { tertemunhas F. e F. (tantas } \\
\text { quantas forem exigidas } \\
\text { conforme o caso), receberam- } \\
\text { se em matrimonio F. (exposto, } \\
\text { filho de F., ou de F. e F. si for } \\
\text { legitimo ou reconhecido), com } \\
\text { annos de idade, natural de } \\
\text { residente em e F. (com as } \\
\text { mesmas declarações, } \\
\text { conforme a filiação), com } \\
\text { annos de idade, natural de } \\
\text { residente em os quaes no } \\
\text { mesmo acto declararam (si } \\
\text { este caso se der) que tinham } \\
\text { tido antes do casamento os } \\
\text { seguintes filhos: F. com annos } \\
\text { de idade, F. com annos de } \\
\text { idade, etc. (ou um filho ou }\end{array}$ & $\begin{array}{l}\text { Art. 195. Do matrimônio, logo } \\
\text { depois de celebrado, se lavrará } \\
\text { o assento no livro de registro } \\
\text { (art. 202). } \\
\text { No assento, assinado pelo } \\
\text { presidente do ato, os cônjuges, } \\
\text { as testemunhas e o oficial de } \\
\text { registro, serão exarados: } \\
\text { I. Os nomes, prenomes, datas } \\
\text { de nascimento, profissão, } \\
\text { domicílio e residência atual } \\
\text { dos cônjuges. } \\
\text { II. Os nomes, prenomes, datas } \\
\text { de nascimento ou de morte, } \\
\text { domicílio e residência atual } \\
\text { dos pais. } \\
\text { III. Os nomes e prenomes do } \\
\text { cônjuge precedente e a data da } \\
\text { dissolução do casamento } \\
\text { anterior. } \\
\text { IV. A data da publicação e da } \\
\text { celebração do casamento. } \\
\text { (Vide Decreto do Poder } \\
\text { Legislativo nº } 3.725, \text { de } \\
\underline{1919) .}\end{array}$ & $\begin{array}{l}\text { Art. 1.536. Do casamento, logo } \\
\text { depois de celebrado, lavrar-se-á } \\
\text { o assento no livro de registro. } \\
\text { No assento, assinado pelo } \\
\text { presidente do ato, pelos } \\
\text { cônjuges, as testemunhas, e o } \\
\text { oficial do registro, serão } \\
\text { exarados: } \\
\text { I - os prenomes, sobrenomes, } \\
\text { datas de nascimento, profissão, } \\
\text { domicílio e residência atual dos } \\
\text { cônjuges; } \\
\text { II - os prenomes, sobrenomes, } \\
\text { datas de nascimento ou de } \\
\text { morte, domicílio e residência } \\
\text { atual dos pais; } \\
\text { III - o prenome e sobrenome do } \\
\text { cônjuge precedente e a data da } \\
\text { dissolução do casamento } \\
\text { anterior; } \\
\text { IV - a data da publicação dos } \\
\text { proclamas e da celebração do } \\
\text { casamento; } \\
\text { V - a relação dos documentos } \\
\text { apresentados ao oficial do } \\
\text { registro; }\end{array}$ \\
\hline
\end{tabular}




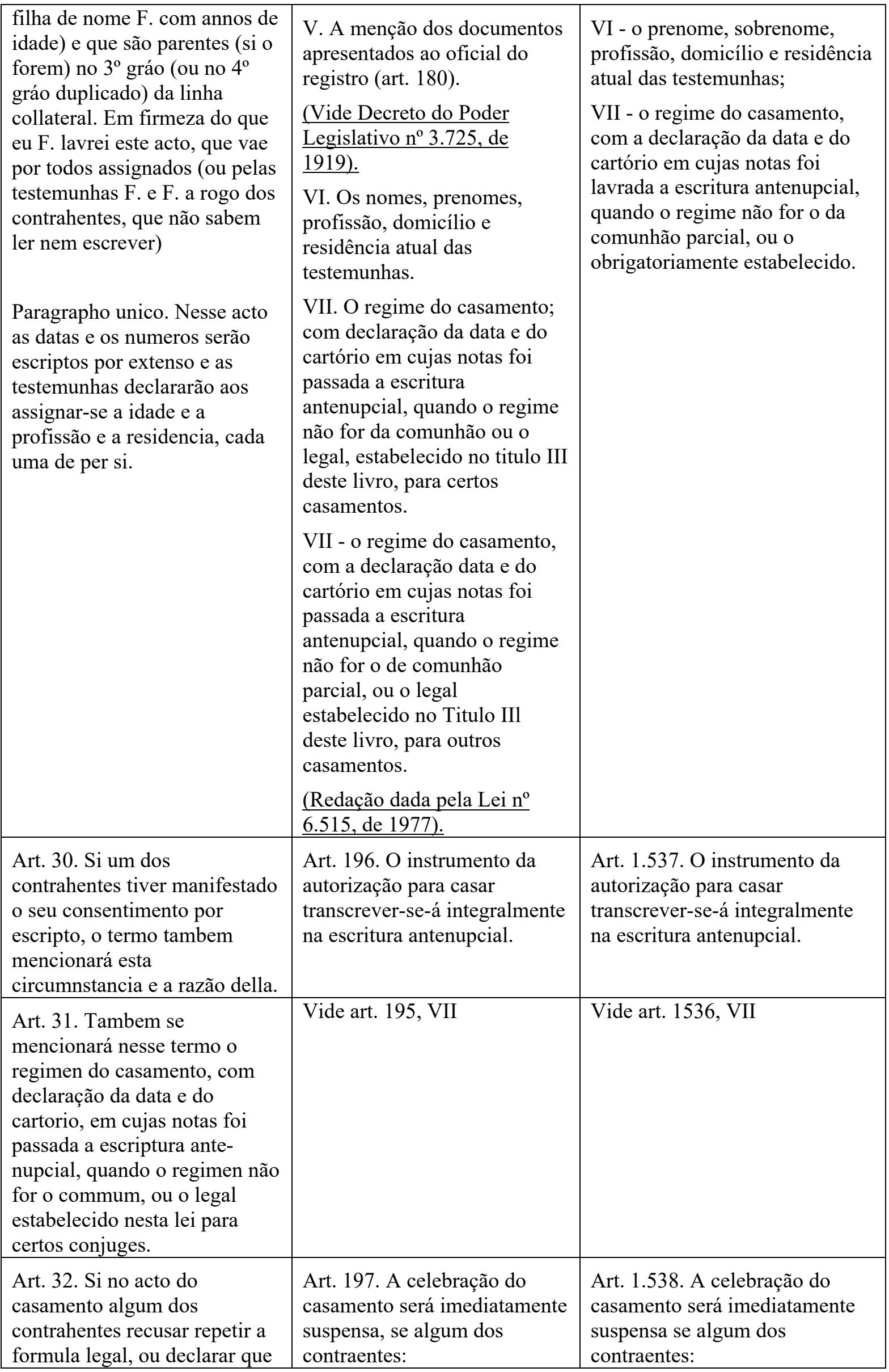




\begin{tabular}{|c|c|c|}
\hline $\begin{array}{l}\text { não se casa por sua vontade } \\
\text { espontanea, ou que está } \\
\text { arrependido, o presidente do } \\
\text { acto suspendel-o-ha } \\
\text { immediatamente, e não } \\
\text { admittirá retractação naquelle } \\
\text { dia. }\end{array}$ & $\begin{array}{l}\text { I. Recusar a solene afirmação } \\
\text { da sua vontade. } \\
\text { II. Declarar que esta não é } \\
\text { livre e espontânea. } \\
\text { III. Manifestar-se arrependido. }\end{array}$ & $\begin{array}{l}\text { I - recusar a solene afirmação da } \\
\text { sua vontade; } \\
\text { II - declarar que esta não é livre } \\
\text { e espontânea; } \\
\text { III - manifestar-se arrependido. }\end{array}$ \\
\hline $\begin{array}{l}\text { Art. } 33 \text {. Si o contrahente } \\
\text { recusante ou arrependido for } \\
\text { mulher e menor de } 21 \text { annos, } \\
\text { não será recebida a casar com } \\
\text { outro contrahente, sem que } \\
\text { este prove que ella está } \\
\text { depositada em logar seguro e } \\
\text { fóra da companhia da pessoa, } \\
\text { sob cujo poder ou } \\
\text { administração se achava na } \\
\text { data da recusa ou } \\
\text { arrependimento. }\end{array}$ & $\begin{array}{l}\text { Parágrafo único. O nubente } \\
\text { que, por algum destes fatos, } \\
\text { der causa à suspensão do ato, } \\
\text { não será admitido a retratar-se } \\
\text { no mesmo dia. }\end{array}$ & $\begin{array}{l}\text { Parágrafo único. O nubente que, } \\
\text { por algum dos fatos } \\
\text { mencionados neste artigo, der } \\
\text { causa à suspensão do ato, não } \\
\text { será admitido a retratar-se no } \\
\text { mesmo dia. }\end{array}$ \\
\hline $\begin{array}{l}\text { Art. } 34 \text {. No caso de molestia } \\
\text { grave de um dos contrahentes, } \\
\text { o presidente do acto será } \\
\text { obrigado a ir assistil-o em casa } \\
\text { do impedido, e mesmo á noite, } \\
\text { comtando que, neste caso, } \\
\text { além das duas testemunhas } \\
\text { exigidas no art. 24, assistam } \\
\text { mais duas que saibam ler e } \\
\text { escrever e sejam maiores de } \\
18 \text { annos. }\end{array}$ & $\begin{array}{l}\text { Art. 198. No caso de moléstia } \\
\text { grave de um dos nubentes, o } \\
\text { presidente do ato irá celebrá- } \\
\text { lo na casa do impedido e, } \\
\text { sendo urgente, ainda à noite, } \\
\text { perante quatro testemunhas, } \\
\text { que saibam ler e escrever. }\end{array}$ & $\begin{array}{l}\text { Art. 1.539. No caso de moléstia } \\
\text { grave de um dos nubentes, o } \\
\text { presidente do ato irá celebrá-lo } \\
\text { onde se encontrar o impedido, } \\
\text { sendo urgente, ainda que à } \\
\text { noite, perante duas testemunhas } \\
\text { que saibam ler e escrever. }\end{array}$ \\
\hline $\begin{array}{l}\text { Art. 35. No referido caso a } \\
\text { falta, ou o impedimento da } \\
\text { autoridade competente para } \\
\text { presidir ao casamento, será } \\
\text { supprida por qualquer dos seus } \\
\text { substitutos legaes, e a do } \\
\text { official do registro civil por } \\
\text { outro ad hoc, nomeado pelo } \\
\text { presidente, e o termo avulso } \\
\text { lavrado por aqulle será } \\
\text { lançado no livro competente } \\
\text { no prazo mais breve possivel. }\end{array}$ & $\begin{array}{l}\text { Art. } 198, \S 1^{\circ} \text { A falta ou } \\
\text { impedimento da autoridade } \\
\text { competente para presidir ao } \\
\text { casamento suprir-se-á por } \\
\text { qualquer dos seus substitutos } \\
\text { legais, e a do oficial do } \\
\text { registro civil por outro ad hoc, } \\
\text { nomeado pelo presidente do } \\
\text { ato. } \\
\S 2^{\circ} \mathrm{O} \text { termo avulso, que o } \\
\text { oficial ad hoc lavrar, será } \\
\text { levado ao registro no mais } \\
\text { breve prazo possível. }\end{array}$ & $\begin{array}{l}\text { Art. } 1539, \S 1^{\circ} \text { A falta ou } \\
\text { impedimento da autoridade } \\
\text { competente para presidir o } \\
\text { casamento suprir-se-á por } \\
\text { qualquer dos seus substitutos } \\
\text { legais, e a do oficial do Registro } \\
\text { Civil por outro ad hoc, } \\
\text { nomeado pelo presidente do ato. } \\
\S 2^{\circ} \text { O termo avulso, lavrado } \\
\text { pelo oficial ad hoc, será } \\
\text { registrado no respectivo registro } \\
\text { dentro em cinco dias, perante } \\
\text { duas testemunhas, ficando } \\
\text { arquivado. }\end{array}$ \\
\hline $\begin{array}{l}\text { Art. 36. Quando algum dos } \\
\text { contrahentes estiver em } \\
\text { imminente risco de vida, ou } \\
\text { for obrigado a ausentar-se } \\
\text { precipitadamente em serviço } \\
\text { publico, obrigatorio e notorio, } \\
\text { o official do registro, }\end{array}$ & & \\
\hline
\end{tabular}




\begin{tabular}{|c|c|c|}
\hline $\begin{array}{l}\text { precedente despacho do } \\
\text { presidente, poderá, á vista dos } \\
\text { documentos exigidos no art. } 1^{\circ} \\
\text { e independente dos proclamas, } \\
\text { dar a certidão de que trata o } \\
\text { art. } 3^{\circ} \text {. }\end{array}$ & & \\
\hline $\begin{array}{l}\text { Art. } 37 \text {. No primeiro dos casos } \\
\text { do artigo antecedente, si os } \\
\text { contrahentes não puderem } \\
\text { obter a presença da autoridade } \\
\text { competente para presidir ao } \\
\text { casamento, nem de algum dos } \\
\text { seus substitutos, poderão } \\
\text { celebrar o seu em presença de } \\
\text { seis testemunhas, maiores de } \\
18 \text { annos, que não sejam } \\
\text { parentes em gráo prohibido do } \\
\text { enfermo, ou que não o sejam } \\
\text { mais delle do que do outro } \\
\text { contrahente. }\end{array}$ & & \\
\hline $\begin{array}{l}\text { Art. } 38 \text {. Essas testemunhas, } \\
\text { dentro de } 48 \text { horas depois do } \\
\text { acto deverão ir apresentar-se á } \\
\text { autoridade judiciaria mais } \\
\text { proxima para pedir-lhe que } \\
\text { faça tomar por termo as suas } \\
\text { declarações. } \\
\text { Art. } 39 \text {. Estas declarações } \\
\text { devem affirmar: } \\
\S 1^{\circ} \text { Que as testemunhas foram } \\
\text { convocadas da parte do } \\
\text { enfermo. } \\
\S 2^{\circ} \text { Que este parecia em } \\
\text { perigo de vida, mas em seu } \\
\text { juizo. } \\
\S 3^{\circ} \text { Que tinha filho do outro } \\
\text { contrahente, ou vivia } \\
\text { concubinado com elle, ou que } \\
\text { o homem havia raptado, ou } \\
\text { deflorado a mulher. } \\
\S 4^{\circ} \text { Que na presença dellas } \\
\text { repetiram os dous as formulas } \\
\text { do casamento, cada qual por } \\
\text { sua vez. }\end{array}$ & $\begin{array}{l}\text { Art. 200. Essas testemunhas } \\
\text { comparecerão dentro em cinco } \\
\text { dias ante a autoridade judicial } \\
\text { mais próxima, pedindo que se } \\
\text { lhes tomem por termo as } \\
\text { seguintes declarações: } \\
\text { I. Que foram convocadas por } \\
\text { parte do enfermo. } \\
\text { II. Que este parecia em perigo } \\
\text { de vida, mas em seu juizo. } \\
\text { III. Que em sua presença } \\
\text { declararam os contraentes } \\
\text { livre e espontaneamente } \\
\text { receber-se por marido e } \\
\text { mulher. }\end{array}$ & $\begin{array}{l}\text { Art. } 1.541 \text {. Realizado o } \\
\text { casamento, devem as } \\
\text { testemunhas comparecer perante } \\
\text { a autoridade judicial mais } \\
\text { próxima, dentro em dez dias, } \\
\text { pedindo que lhes tome por } \\
\text { termo a declaração de: } \\
\text { I - que foram convocadas por } \\
\text { parte do enfermo; } \\
\text { II - que este parecia em perigo } \\
\text { de vida, mas em seu juízo; } \\
\text { III - que, em sua presença, } \\
\text { declararam os contraentes, livre } \\
\text { e espontaneamente, receber-se } \\
\text { por marido e mulher. }\end{array}$ \\
\hline $\begin{array}{l}\text { Art. } 40 \text {. Autoado o pedido e } \\
\text { tomados os depoimentos, o } \\
\text { juiz procederá ás diligencias } \\
\text { necessarias para verificar si os } \\
\text { contrahentes podiam ter-se } \\
\text { habilitado nos termos do art. } \\
1^{\circ} \text { para casar-se na fórma }\end{array}$ & $\begin{array}{l}\S 1^{\circ} \text { Autuado o pedido e } \\
\text { tomadas as declarações, o juiz } \\
\text { procederá às diligências } \\
\text { necessárias para verificar se } \\
\text { os contraentes podiam ter-se } \\
\text { habilitado para o casamento, } \\
\text { na forma ordinária, ouvidos os }\end{array}$ & $\begin{array}{l}\S 1^{\circ} \text { Autuado o pedido e } \\
\text { tomadas as declarações, o juiz } \\
\text { procederá às diligências } \\
\text { necessárias para verificar se os } \\
\text { contraentes podiam ter-se } \\
\text { habilitado, na forma ordinária, } \\
\text { ouvidos os interessados que o }\end{array}$ \\
\hline
\end{tabular}




ordinaria, ouvindo os
interessados pró e contra, que
lhe requererem, dentro de 15
dias.
Art. 41. Terminadas as
diligencias e verificadas a
idoneidade dos contrahentes
para casar-se um com o outro,
assim o decidirá, si for
magistrado, ou remetterá ao
juiz competente para decidir, e
das decisões deste poderão as
partes aggravar de petição ou
instrumento.

Art. 42. Si da decisão não houver recurso, ou logo que ella passe em julgado, apezar dos recursos que lhe forem oppostos, o juiz mandará registrar a sua decisão no livro do registro dos casamentos.

Art. 43. Este registro fará retrotrahir os effeitos do casamento, em relação ao estado dos conjunges á data da celebração, e em relação aos filhos communs á data do nascimento, si nascerem viaveis.

Paragrapho unico. Serão dispensadas as formalidades dos arts. 38 a 42, si o enfermo convalescer e puder ratificar o casamento em presença do juiz e do official do registro civil.

Art. 44. Em caso urgente e de força maior, em que um dos contrahentes não possa transportar-se ao logar da residencia do outro, nem demorar o casamento, poderá o noivo impedido fazer-se representar no acto por um procurador bastante e especial para receber em seu nome o outro contrahente, cuja designação certa deverá ser interessados, que o

requererem, dentro em quinze dias.

$\S 2^{\circ}$ Verificada a idoneidade dos cônjuges para o casamento, assim o decidirá a autoridade competente, com recurso voluntário às partes.

$\S 3^{\circ}$ Se da decisão não se tiver recorrido, ou se ela passar em julgado, apesar dos recursos interpostos, o juiz mandará transcrevê-la no livro do registro dos casamentos.

$\S 4^{\circ} \mathrm{O}$ assento assim lavrado retrotrairá os efeitos do casamento, quanto ao estado dos cônjuges, à data da celebração e, quanto aos filhos comuns, à data do nascimento.

$\S 5^{\circ}$ Serão dispensadas as formalidade deste e do artigo anterior, se o enfermo convalescer e puder ratificar o casamento em presença da autoridade competente e do oficial do registro. requererem, dentro em quinze dias.

$\S 2^{\circ}$ Verificada a idoneidade dos cônjuges para o casamento, assim o decidirá a autoridade competente, com recurso voluntário às partes.

$\S 3^{\circ}$ Se da decisão não se tiver recorrido, ou se ela passar em julgado, apesar dos recursos interpostos, o juiz mandará registrá-la no livro do Registro dos Casamentos.

$\S 4^{\circ} \mathrm{O}$ assento assim lavrado retrotrairá os efeitos do casamento, quanto ao estado dos cônjuges, à data da celebração.

$\S 5^{\circ}$ Serão dispensadas as formalidades deste e do artigo antecedente, se o enfermo convalescer e puder ratificar o casamento na presença da autoridade competente e do oficial do registro. 


\begin{tabular}{|c|c|c|}
\hline $\begin{array}{l}\text { feita no instrumento da } \\
\text { procuração. }\end{array}$ & & \\
\hline $\begin{array}{l}\text { Art. 45. O estrangeiro, } \\
\text { residente fóra do Brazil, não } \\
\text { poderá casar-se nelle com } \\
\text { brazileira por procuração, sem } \\
\text { provar que a sua lei nacional } \\
\text { admitte a validade do } \\
\text { casamento feito por este meio. }\end{array}$ & $\begin{array}{l}\text { Art. } 201 . \text { O casamento pode } \\
\text { celebrar-se mediante } \\
\text { procuração, que outorgue } \\
\text { poderes especiais ao } \\
\text { mandatário para receber, em } \\
\text { nome do outorgante, o outro } \\
\text { contraente. } \\
\text { Parágrafo único. Pode casar } \\
\text { por procuração o preso, ou o } \\
\text { condenado, quando lhe não } \\
\text { permita comparecer em } \\
\text { pessoa a autoridade, sob cuja } \\
\text { guarda estiver. }\end{array}$ & $\begin{array}{l}\text { Art. } 1.542 \text {. O casamento pode } \\
\text { celebrar-se mediante } \\
\text { procuração, por instrumento } \\
\text { público, com poderes especiais. } \\
\S 1^{\circ} \text { A revogação do mandato } \\
\text { não necessita chegar ao } \\
\text { conhecimento do mandatário; } \\
\text { mas, celebrado o casamento sem } \\
\text { que o mandatário ou o outro } \\
\text { contraente tivessem ciência da } \\
\text { revogação, responderá o } \\
\text { mandante por perdas e danos. } \\
\S 2^{\circ} \text { O nubente que não estiver } \\
\text { em iminente risco de vida } \\
\text { poderá fazer-se representar no } \\
\text { casamento nuncupativo. } \\
\S 3^{\circ} \text { A eficácia do mandato não } \\
\text { ultrapassará noventa dias. } \\
\S 4^{\circ} \text { Só por instrumento público } \\
\text { se poderá revogar o mandato. }\end{array}$ \\
\hline $\begin{array}{l}\text { Art. 46. Quando os } \\
\text { contrahentes forem parentes } \\
\text { dentro do } 3^{\circ} \text { gráo civil, ou do } \\
4^{\circ} \text { gráo duplicado, o seu } \\
\text { parentesco será declarado no } \\
\text { registro de que trata o art. } 29, \\
\text { e nos attestados das } \\
\text { testemunhas, a que se refere o } \\
\S 4^{\circ} \text { do art. } 1^{\circ}\end{array}$ & & \\
\hline \multicolumn{3}{|c|}{$\begin{array}{l}\text { DO CASAMENTO DOS BRASILEIROS NO ESTRANGEIRO E DOS ESTRANGEIROS NO } \\
\text { BRASIL }\end{array}$} \\
\hline $\begin{array}{l}\text { Art. } 47 . \text { O casamento dos } \\
\text { brazileiros no estrangeiro deve } \\
\text { ser feito de accordo com as } \\
\text { disposições seguintes: } \\
\S 1^{\circ} \mathrm{Si} \text { ambos ou um só dos } \\
\text { contrahentes é brazileiro, o } \\
\text { casamento póde ser feito na } \\
\text { fórma usada no paiz onde for } \\
\text { celebrado. } \\
\S 2^{\circ} \mathrm{Si} \text { ambos os contrahentes } \\
\text { forem brazileiros, podem } \\
\text { tambem casar-se, na fórma da } \\
\text { lei nacional, perante o agente } \\
\text { diplomatico, ou consular do } \\
\text { Brazil. }\end{array}$ & & \\
\hline
\end{tabular}


$\S 3^{\circ}$ Os casamentos de que trata o paragrapho antecedente estão sujeitos ás formalidades e aos impedimentos previstos nesta lei, os quaes serão devolvidos ao conhecimento do poder judicial do Brazil, e só depois de solvidos por elle se considerarão levantados onde foram oppostos.

$\S 4^{\circ}$ Os mesmos casamentos devem ser registrados no Brazil á vista dos documentos de que trata $o$ art. $1^{\circ}$, tres mezes depois de celebrados, ou um mez depois que os conjuges ou, ao menos, um delles voltar ao paiz.

Art. 48. As disposições desta lei relativas as causas de impedimento e ás formalidades preliminares são applicaveis aos casamentos de estrangeiros celebrados no Brazil.

\section{DAS PROVAS DO CASAMENTO}

Art. 49. A celebração do casamento contrahido no Brazil, depois do estabelecimento do registro civil, deve ser provada por certidão extrahida do mesmo registro; mas, provando-se a perda deste, é admissivel qualquer outra especie de prova.

Art. 50. Os casamentos contrahidos antes do estabelecimento daquelle registro devem ser provados por certidão extrahida dos livros parochiaes respectivos, ou na falta destes, por qualquer outra especie de prova.
Art. 202. O casamento celebrado no Brasil prova-se pela certidão do registro, feito ao tempo de sua celebração (art. 195).

Parágrafo único. Justificada a falta ou perda do registro civil, é admissível qualquer outra espécie de prova.
Art. 1.543. O casamento celebrado no Brasil prova-se pela certidão do registro.

Parágrafo único. Justificada a falta ou perda do registro civil, é admissível qualquer outra espécie de prova. 


\begin{tabular}{|c|c|c|}
\hline $\begin{array}{l}\text { Art. } 51 . \text { Ninguem póde, } \\
\text { porém, contestar o casamento } \\
\text { de pessoas fallecidas na posse } \\
\text { desse estado, em prejuizo dos } \\
\text { filhos das mesmas pessoas, } \\
\text { salvo provando, por certidão } \\
\text { extrahida do registro civil ou } \\
\text { dos livros parochiaes, que } \\
\text { alguma dellas era casada com } \\
\text { outra pessoa. }\end{array}$ & $\begin{array}{l}\text { Art. 203. O casamento de } \\
\text { pessoas que faleceram na } \\
\text { posse do estado de casados } \\
\text { não se pode contestar em } \\
\text { prejuízo da prole comum, } \\
\text { salvo mediante certidão do } \\
\text { registro civil, que prove que já } \\
\text { era casada alguma delas, } \\
\text { quando contraiu o matrimônio } \\
\text { impugnado (art. } 183, \mathrm{n}^{\circ} \mathrm{VI} \text { ). }\end{array}$ & $\begin{array}{l}\text { Art. } 1.545 \text {. O casamento de } \\
\text { pessoas que, na posse do estado } \\
\text { de casadas, não possam } \\
\text { manifestar vontade, ou tenham } \\
\text { falecido, não se pode contestar } \\
\text { em prejuízo da prole comum, } \\
\text { salvo mediante certidão do } \\
\text { Registro Civil que prove que já } \\
\text { era casada alguma delas, quando } \\
\text { contraiu o casamento } \\
\text { impugnado. }\end{array}$ \\
\hline $\begin{array}{l}\text { Art. } 52 \text {. O casamento } \\
\text { contrahido em paiz estrangeiro } \\
\text { poderá provar-se por qualquer } \\
\text { dos meios legaes, admittidos } \\
\text { no mesmo paiz, salvo o caso } \\
\text { do } \S 2^{\circ} \text { do art. } 47 \text {, no qual a } \\
\text { prova deverá ser feita na } \\
\text { fórma do } \S 4^{\circ} \text { do mesmo } \\
\text { artigo. }\end{array}$ & $\begin{array}{l}\text { Art. 204. O casamento } \\
\text { celebrado fora do Brasil } \\
\text { prova-se de acordo com a lei } \\
\text { do país, onde se celebrou. } \\
\text { Parágrafo único. Se, porém, se } \\
\text { contraiu perante agente } \\
\text { consular, provar-se-á por } \\
\text { certidão do assento no registro } \\
\text { do consulado. }\end{array}$ & $\begin{array}{l}\text { Art. 1.544. O casamento de } \\
\text { brasileiro, celebrado no } \\
\text { estrangeiro, perante as } \\
\text { respectivas autoridades ou os } \\
\text { cônsules brasileiros, deverá ser } \\
\text { registrado em cento e oitenta } \\
\text { dias, a contar da volta de um ou } \\
\text { de ambos os cônjuges ao Brasil, } \\
\text { no cartório do respectivo } \\
\text { domicílio, ou, em sua falta, no } \\
\text { 1 Ofício da Capital do Estado }_{\text {em que passarem a residir. }}\end{array}$ \\
\hline $\begin{array}{l}\text { Art. 53. Quando for contestada } \\
\text { a existencia do casamento, e } \\
\text { forem contradictorias e } \\
\text { equivalentes as provas } \\
\text { exhibidas de parte a parte, a } \\
\text { duvida será resolvida em favor } \\
\text { do mesmo casamento, si os } \\
\text { conjuges questionados tiverem } \\
\text { vivido, ou viverem na posse } \\
\text { desse estado. }\end{array}$ & $\begin{array}{l}\text { Art. } 206 \text {. Na dúvida entre as } \\
\text { provas por e contra, julgar-se- } \\
\text { á pelo casamento, se os } \\
\text { cônjuges, cujo matrimônio se } \\
\text { impugna, vierem ou tiverem } \\
\text { vivido na posse do estado de } \\
\text { casados. }\end{array}$ & $\begin{array}{l}\text { Art. 1.547. Na dúvida entre as } \\
\text { provas favoráveis e contrárias, } \\
\text { julgar-se-á pelo casamento, se } \\
\text { os cônjuges, cujo casamento se } \\
\text { impugna, viverem ou tiverem } \\
\text { vivido na posse do estado de } \\
\text { casados. }\end{array}$ \\
\hline $\begin{array}{l}\text { Art. 54. Quando houver } \\
\text { indicios de que, por culpa ou } \\
\text { fraude do official, o acto do } \\
\text { casamento deixou de ser } \\
\text { incripto no livro do registro, os } \\
\text { conjuges poderão proval-o } \\
\text { pelos meios subsidiarios } \\
\text { admittidos para supprir a falta } \\
\text { do registro dos actos do estado } \\
\text { civil. }\end{array}$ & & \\
\hline $\begin{array}{l}\text { Art. 55. Quando a prova da } \\
\text { celebração legal de um } \\
\text { casamento resultar de um } \\
\text { processo judicial, a inscripção } \\
\text { do julgado no respectivo } \\
\text { registro produzirá, quer a } \\
\text { respeito dos conjuges, quer } \\
\text { dos filhos, todos os effeitos }\end{array}$ & $\begin{array}{l}\text { Art. 205. Quando a prova da } \\
\text { celebração legal do casamento } \\
\text { resultar de processo judicial, a } \\
\text { inscrição da sentença no livro } \\
\text { do registro civil produzirá, } \\
\text { assim no que toca aos } \\
\text { cônjuges, como no que } \\
\text { respeita aos filhos, todos os }\end{array}$ & $\begin{array}{l}\text { Art. 1.546. Quando a prova da } \\
\text { celebração legal do casamento } \\
\text { resultar de processo judicial, o } \\
\text { registro da sentença no livro do } \\
\text { Registro Civil produzirá, tanto } \\
\text { no que toca aos cônjuges como } \\
\text { no que respeita aos filhos, todos }\end{array}$ \\
\hline
\end{tabular}




\begin{tabular}{|l|l|l|}
\hline $\begin{array}{l}\text { civis, desde a data da } \\
\text { celebração do mesmo } \\
\text { casamento. }\end{array}$ & $\begin{array}{l}\text { efeitos civis desde a data do } \\
\text { casamento. }\end{array}$ & $\begin{array}{l}\text { os efeitos civis desde a data do } \\
\text { casamento. }\end{array}$ \\
\hline
\end{tabular}

\section{DOS EFFEITOS DO CASAMENTO}

Art. 56. São effeitos do casamento:

$\S 1^{\circ}$ Constituir familia legitima e legitimar os filhos anteriormente havidos de um dos contrahentes com o outro, salvo si um destes ao tempo do nascimento, ou da concepção dos mesmos filhos, estiver casado com outra pessoa.

$\S 2^{\circ}$ Investir o marido da representação legal da familia e da administração dos bens communs, e daquelles que, por contracto ante-nupcial, devam ser administrados por elle.

$\S 3^{\circ}$ Investir o marido do direito de fixar o domicilio da familia, de autorizar a profissão da mulher e dirigir a educação dos filhos.

$\S 4^{\circ}$ Conferir á mulher o direito de usar do nome da familia do marido e gozar das suas honras e direitos, que pela legislação brazileira se possam communicar a ella.

$\S 5^{\circ}$ Obrigar o marido a sustentar e defender a mulher e os filhos.

$\S 6^{\circ}$ Determinar os direitos e deveres reciprocos, na fórma da legislação civil, entre o marido e a mulher e entre elles e os filhos.
Art. 229. Criando a família legítima, o casamento legitima os filhos comuns, antes dele nascidos ou concebidos (arts. 352 a 354).

Art. 233. O marido é o chefe da sociedade conjugal.

Compete-lhe:

I. A representação legal da família.

II. A administração dos bens comuns e dos particulares da mulher, que ao marido competir administrar em virtude do regime matrimonial adaptado, ou do pacto antenupcial (arts. $178, \S 9^{\circ}, \mathrm{n}^{\circ}$ I, c, 274, 289, $\mathrm{n}^{\circ} \mathrm{I}$, e 311 ).

III. direito de fixar e mudar o domicílio da família (arts. 46 e 233, $n^{\circ}$ IV).

(Vide Decreto do Poder

Legislativo $\mathrm{n}^{\circ} 3.725$, de 1919).

IV. O direito de autorizar a profissão da mulher e a sua residência fora do tecto conjugal (arts. 231, $\mathrm{n}^{\mathrm{o}}$ II, 242, $\mathrm{n}^{\circ}$ VII, 243 a $245, \mathrm{n}^{\circ}$ II, e 247, $\mathrm{n}^{\mathrm{o}}$ III).

V. Prover à manutenção da família, guardada a disposição do art. 277.

Art. 233. O marido é o chefe da sociedade conjugal, função que exerce com a colaboração da mulher, no interêsse
Art. 1.565. Pelo casamento, homem e mulher assumem mutuamente a condição de consortes, companheiros e responsáveis pelos encargos da família.

Art. 1.567. A direção da sociedade conjugal será exercida, em colaboração, pelo marido e pela mulher, sempre no interesse do casal e dos filhos.

Parágrafo único. Havendo divergência, qualquer dos cônjuges poderá recorrer ao juiz, que decidirá tendo em consideração aqueles interesses.

Art. 1.568. Os cônjuges são obrigados a concorrer, na proporção de seus bens e dos rendimentos do trabalho, para o sustento da família e a educação dos filhos, qualquer que seja o regime patrimonial. 
comum do casal e dos filhos

(arts. 240, 247 e 251).

(Redação dada pela Lei $\mathrm{n}^{\circ}$

4.121, de 1962).

Compete-lhe:

I - A representação legal da

família;

(Redação dada pela Lei $\mathrm{n}^{\circ}$

4.121, de 1962).

II - a administração dos bens

comuns e dos particulares da

mulher que ao marido

incumbir administrar, em

virtude do regime matrimonial adotado, ou de pacto,

antenupcial (arts. $178, \S 9^{\circ}, \mathrm{n}^{\circ}$ I, c, 274, 289, no I e 311);

(Redação dada pela Lei $\mathrm{n}^{\circ}$

4.121, de 1962).

III - o direito de fixar o

domicílio da família

ressalvada a possibilidade de

recorrer a mulher ao Juiz, no

caso de deliberação que a

prejudique;

(Redação dada pela Lei $\mathrm{n}^{\circ}$

4.121, de 1962).

IV - prover a manutenção da

família, guardadas as

disposições dos arts. $275 \mathrm{e}$

277.

(Redação dada pela Lei $\mathrm{n}^{\circ}$

4.121, de 1962).

Art. 234. A obrigação de sustentar a mulher cessa, para o marido, quando ela abandona sem justo motivo a habitação conjugal, e a esta recusa voltar. Neste caso, o juiz pode, segundo as circunstâncias, ordenar, em proveito do marido e dos filhos, o sequestro temporário de parte dos rendimentos particulares da mulher.

Art. 235. O marido não pode, sem consentimento da mulher, qualquer que seja o regime de bens:

I. Alienar, hipotecar ou gravar de onus real os bens imóveis, 


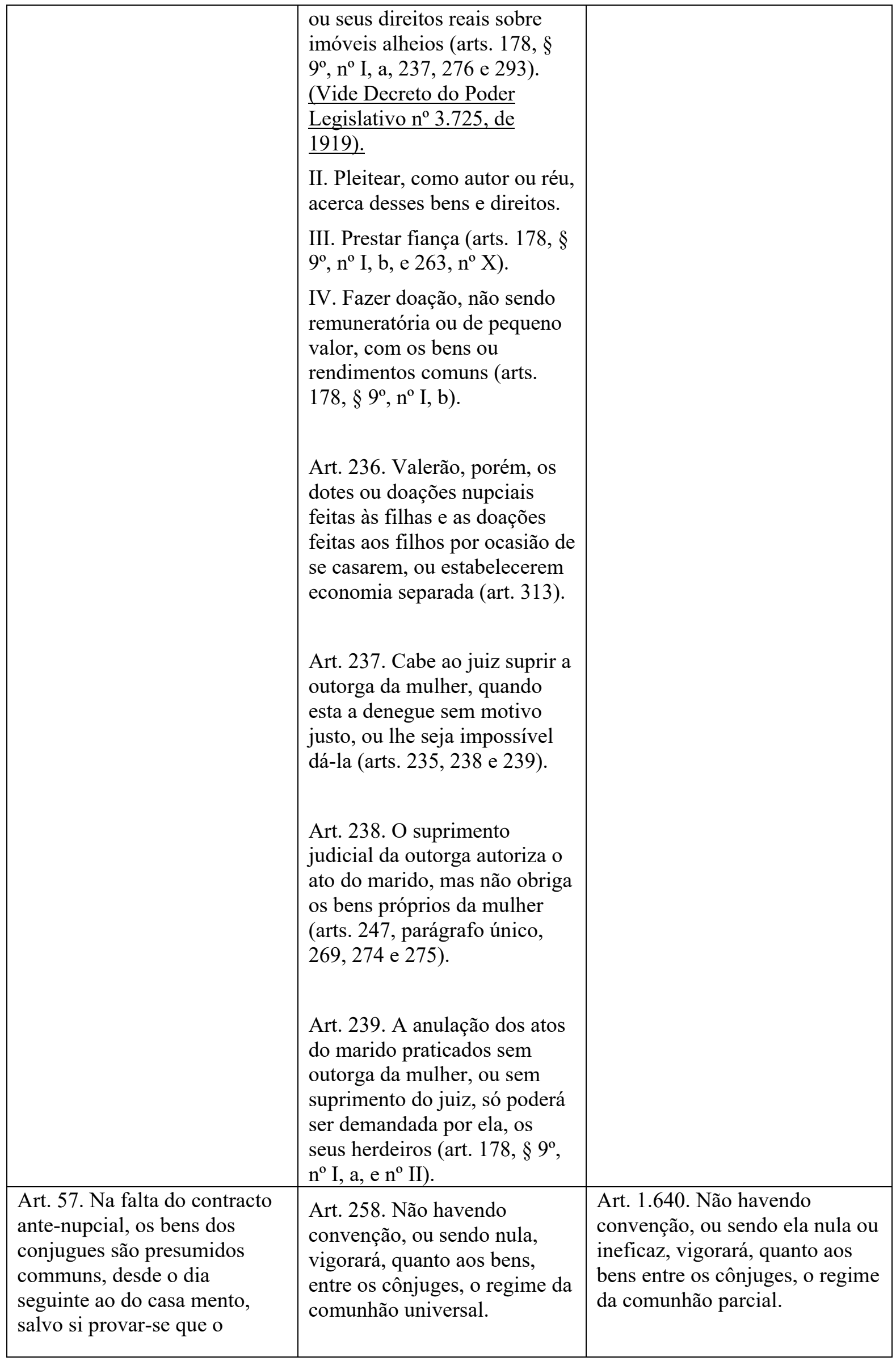




\begin{tabular}{|c|c|c|}
\hline $\begin{array}{l}\text { matrimonio não foi } \\
\text { consummado entre elles. } \\
\text { Paragrapho unico. Esta prova } \\
\text { não será admissivel quando } \\
\text { tiverem filhos anteriores ao } \\
\text { casamento, ou forem } \\
\text { concubinados antes delle, ou } \\
\text { este houver sido precedido de } \\
\text { rapto. }\end{array}$ & & \\
\hline $\begin{array}{l}\text { Art. } 58 \text {. Tambem não haverá } \\
\text { communhão de bens: } \\
\S 1^{\circ} \text { Si a mulher for menor de } \\
14 \text { annos, ou maior de } 50 \text {. } \\
\S 2^{\circ} \text { Si o marido for menor de } \\
16 \text {, ou maior de } 60 \text {. } \\
\S 3^{\circ} \text { Si os conjuges forem } \\
\text { parentes dentro do } 3^{\circ} \text { gráo } \\
\text { civil ou do } 4^{\circ} \text { duplicado. } \\
\S 4^{\circ} \text { Si o casamento for } \\
\text { contrahido com infracção do } \S \\
11 \text { ou do } \S 12 \text { do art. } 7^{\circ} \text {, ainda } \\
\text { que neste caso tenha precedido } \\
\text { licença, do presidente da } \\
\text { Relação do respectivo } \\
\text { districto. } \\
\text { Art. } 59 \text {. Em cada um dos casos } \\
\text { dos paragraphos do artigo } \\
\text { antecedente, todos os bens da } \\
\text { mulher, presentes e futuros, } \\
\text { serão considerados dotaes, e } \\
\text { como taes garantidos na fórma } \\
\text { do direito civil. }\end{array}$ & 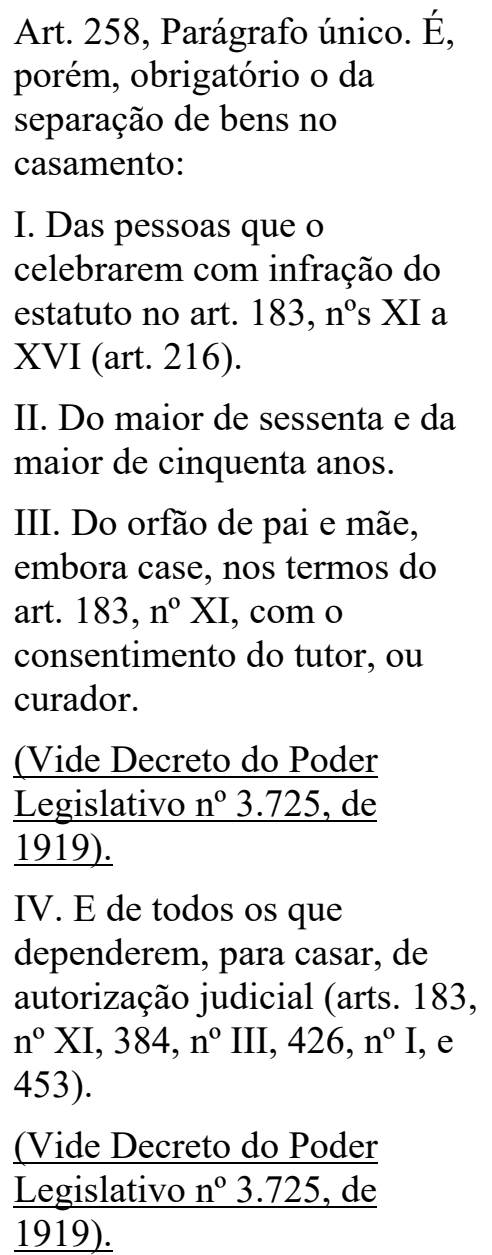 & $\begin{array}{l}\text { Art. 1.641. É obrigatório o } \\
\text { regime da separação de bens no } \\
\text { casamento: } \\
\text { I - das pessoas que o contraírem } \\
\text { com inobservância das causas } \\
\text { suspensivas da celebração do } \\
\text { casamento; } \\
\text { II - da pessoa maior de sessenta } \\
\text { anos; } \\
\text { II - da pessoa maior de } 70 \\
\text { (setenta) anos; (Redação dada } \\
\text { pela Lei no } 12.344, \text { de } 2010) \\
\text { III - de todos os que } \\
\text { dependerem, para casar, de } \\
\text { suprimento judicial. }\end{array}$ \\
\hline $\begin{array}{l}\text { Art. } 60 . \text { A faculdade } \\
\text { conferida pela segunda parte } \\
\text { do art. } 27 \text { do codigo } \\
\text { commercial á mulher casada } \\
\text { para hypothecar ou alhear o } \\
\text { seu dote é restricta ás que, } \\
\text { antes do casamento, já eram } \\
\text { commerciantes. }\end{array}$ & $\begin{array}{l}\text { Art. } 308 \text {. A mulher pode } \\
\text { requerer judicialmente a } \\
\text { separação do dote, quando a } \\
\text { desordem nos negócios do } \\
\text { marido leve a recear que os } \\
\text { bens deste não bastem a } \\
\text { assegurar os dela; salvo o } \\
\text { direito, que aos credores } \\
\text { assiste, de se oporem á } \\
\text { separação, quando } \\
\text { fraudulenta. } \\
\text { Art. } 309 \text {. Separado o dote, terá } \\
\text { por administradora a mulher, } \\
\text { mas continuará inalienável, }\end{array}$ & \\
\hline
\end{tabular}




\begin{tabular}{|c|c|c|}
\hline & $\begin{array}{l}\text { provendo o juiz, quando } \\
\text { conceder a separação, a que } \\
\text { sejam convertidos em imóveis } \\
\text { os valores entregues pelo } \\
\text { marido em reposição dos bens } \\
\text { dotais. } \\
\text { Parágrafo único. A sentença } \\
\text { da separação será averbada no } \\
\text { registro de que trata o art. } 261 \text {, } \\
\text { para produzir efeitos em } \\
\text { relação a terceiros. }\end{array}$ & \\
\hline \multicolumn{3}{|c|}{ DO CASAMENTO NULO E DO ANULÁVEL } \\
\hline $\begin{array}{l}\text { Art. } 61 \text {. E' nullo e não produz } \\
\text { effeito em relação aos } \\
\text { contrahentes, nem em relação } \\
\text { aos filhos, o casamento feito } \\
\text { com infracção de qualquer dos } \\
\S \S 1^{\circ} \text { a } 4^{\circ} \text { do art. } 7^{\circ}\end{array}$ & $\begin{array}{l}\text { Art. 207. É nulo e de nenhum } \\
\text { efeito, quanto aos contraentes } \\
\text { e aos filhos, o casamento } \\
\text { contraído com infração de } \\
\text { qualquer dos no s I a VIII do } \\
\text { art. 183. Art. 208. É também } \\
\text { nulo o casamento contraído } \\
\text { perante autoridade } \\
\text { incompetente (arts. 192, 194, } \\
195 \text { e 198). Mas esta nulidade } \\
\text { se considerará sanada, se não } \\
\text { se alegar dentro em dois anos } \\
\text { da celebração. }\end{array}$ & $\begin{array}{l}\text { Art. 1.548. É nulo o casamento } \\
\text { contraído: } \\
\text { I - pelo enfermo mental sem o } \\
\text { necessário discernimento para } \\
\text { os atos da vida } \\
\text { civil; } \underline{\text { (Revogado); (Redação }} \\
\underline{\text { dada pela Lei no } 13.146, \text { de }} \\
\underline{2015)} \\
\text { II - por infringência de } \\
\text { impedimento. }\end{array}$ \\
\hline $\begin{array}{l}\text { Art. } 62 \text {. A declaração dessa } \\
\text { nullidade póde ser pedida por } \\
\text { qualquer pessoa, que tenha } \\
\text { interesse nella, ou ex-officio } \\
\text { pelo orgão do ministerio } \\
\text { publico. }\end{array}$ & $\begin{array}{l}\text { Parágrafo único. Antes de } \\
\text { vencido esse prazo, a } \\
\text { declaração da nulidade poderá } \\
\text { ser requerida: } \\
\text { I. Por qualquer interessado. } \\
\text { II. Pelo Ministério Público, } \\
\text { salvo se já houver falecido } \\
\text { algum dos cônjuges. }\end{array}$ & $\begin{array}{l}\text { Art. 1.549. A decretação de } \\
\text { nulidade de casamento, pelos } \\
\text { motivos previstos no artigo } \\
\text { antecedente, pode ser } \\
\text { promovida mediante ação direta, } \\
\text { por qualquer interessado, ou } \\
\text { pelo Ministério Público. }\end{array}$ \\
\hline $\begin{array}{l}\text { Art. } 63 . \text { E' annullavel o }^{\prime} \text { casamento contrahido com } \\
\text { infracção de qualquer dos } \S \S \\
5^{\circ} \text { a } 8^{\circ} \text { do art. } 7^{\circ}\end{array}$ & $\begin{array}{l}\text { Art. 209. É anulável o } \\
\text { casamento contraído com } \\
\text { infração de qualquer dos } n^{\circ} \mathrm{s} \\
\text { IX a XII do art. } 183 \text {. }\end{array}$ & $\begin{array}{l}\text { Art. 1.550. É anulável o } \\
\text { casamento: } \\
\text { I - de quem não completou a } \\
\text { idade mínima para casar; } \\
\text { II - do menor em idade núbil, } \\
\text { quando não autorizado por seu } \\
\text { representante legal; } \\
\text { III - por vício da vontade, nos } \\
\text { termos dos arts. } 1.556 \text { a } 1.558 ; \\
\text { IV - do incapaz de consentir ou } \\
\text { manifestar, de modo } \\
\text { inequívoco, o consentimento; }\end{array}$ \\
\hline
\end{tabular}




\begin{tabular}{|c|c|c|}
\hline & & $\begin{array}{l}\text { V - realizado pelo mandatário, } \\
\text { sem que ele ou o outro } \\
\text { contraente soubesse da } \\
\text { revogação do mandato, e não } \\
\text { sobrevindo coabitação entre os } \\
\text { cônjuges; } \\
\text { VI - por incompetência da } \\
\text { autoridade celebrante. } \\
\S 1^{\circ} \text {. Equipara-se à revogação a } \\
\text { invalidade do mandato } \\
\text { judicialmente decretada. } \\
\S 2^{o} \text { A pessoa com deficiência } \\
\text { mental ou intelectual em idade } \\
\text { núbia poderá contrair } \\
\text { matrimônio, expressando sua } \\
\text { vontade diretamente ou por } \\
\text { meio de seu responsável ou } \\
\text { curador. } \\
\text { (Incluído pela Lei } n^{\circ} 13.146, \text { de } \\
2015)\end{array}$ \\
\hline $\begin{array}{l}\text { Art. 64. A annullação do } \\
\text { casamento, por coacção de um } \\
\text { dos conjuges, só póde ser } \\
\text { pedida pelo coacto dentro dos } \\
\text { seis mezes seguintes á data em } \\
\text { que tiver cessado o seu estado } \\
\text { de coação. }\end{array}$ & $\begin{array}{l}\text { Art. } 210 \text {. A anulação do } \\
\text { casamento contraído pelo } \\
\text { coacto ou pelo incapaz de } \\
\text { consentir, só pode ser } \\
\text { promovida: } \\
\text { I. Pelo próprio coacto. } \\
\text { II. Pelo incapaz. } \\
\text { III. Por seus representantes } \\
\text { legais. }\end{array}$ & \\
\hline $\begin{array}{l}\text { Art. } 65 . \text { A annullação do } \\
\text { casamento, feito por pessoa } \\
\text { incapaz de consentir, só póde } \\
\text { ser promovida por ella mesma, } \\
\text { quando se tornar capaz, ou por } \\
\text { seus representantes legaes nos } \\
\text { seis mezes seguintes ao } \\
\text { casamento, ou pelos seus } \\
\text { herdeiros dentro de igual } \\
\text { prazo, depois de sua morte, si } \\
\text { esta se verificar, continuando a } \\
\text { incapacidade. }\end{array}$ & $\begin{array}{l}\text { Art. } 211 . \text { O que contraiu } \\
\text { casamento, enquanto incapaz, } \\
\text { pode ratifica-lo, quando } \\
\text { adquirir a necessária } \\
\text { capacidade, e esta ratificação } \\
\text { retroagirá os seus efeitos á } \\
\text { data da celebração. }\end{array}$ & $\begin{array}{l}\text { Art. 1.553. O menor que não } \\
\text { atingiu a idade núbil poderá, } \\
\text { depois de completá-la, } \\
\text { confirmar seu casamento, com a } \\
\text { autorização de seus } \\
\text { representantes legais, se } \\
\text { necessária, ou com suprimento } \\
\text { judicial. } \\
\text { Art. } 1.555 \text {. O casamento do } \\
\text { menor em idade núbil, quando } \\
\text { não autorizado por seu } \\
\text { representante legal, só poderá } \\
\text { ser anulado se a ação for } \\
\text { proposta em cento e oitenta dias, } \\
\text { por iniciativa do incapaz, ao } \\
\text { deixar de sê-lo, de seus } \\
\text { representantes legais ou de seus } \\
\text { herdeiros necessários. }\end{array}$ \\
\hline $\begin{array}{l}\text { Art. } 66 . \mathrm{Si} \text { a pessoa incapaz } \\
\text { tornar-se capaz depois do }\end{array}$ & & \\
\hline
\end{tabular}




\begin{tabular}{|c|c|c|}
\hline $\begin{array}{l}\text { casamento e ratifical-o, antes } \\
\text { delle ter sido annullado, a sua } \\
\text { ratificação retrotrahirá á data } \\
\text { do mesmo casamento. }\end{array}$ & & \\
\hline $\begin{array}{l}\text { Art. } 67 . \text { A annullação do } \\
\text { casamento feito com infracção } \\
\text { do } \S 7^{\circ} \text { do art. } 7^{\circ} \text { só póde ser } \\
\text { pedida pelas pessoas que } \\
\text { tinham o direito de consentir e } \\
\text { não assistiram ao acto, dentro } \\
\text { dos tres mezes seguintes á data } \\
\text { em que tiverem conhecimento } \\
\text { do casamento. }\end{array}$ & & \\
\hline $\begin{array}{l}\text { Art. } 68 \text {. A annullação do } \\
\text { casamento da menor de } 14 \\
\text { annos ou do menor de } 16 \\
\text { annos só póde ser pedida pelo } \\
\text { proprio conjuge menor até seis } \\
\text { mezes depois de attingir } \\
\text { aquella idade, ou pelos seus } \\
\text { representantes legaes, ou pelas } \\
\text { pessoas mencionadas no art. } \\
15 \text {, observada a ordem em que } \\
\text { o são, até seis mezes depois do } \\
\text { casamento. } \\
\text { Art. } 69 . \text { Si a annullação do } \\
\text { casamento for pedida por } \\
\text { terceiro, fica salvo aos } \\
\text { conjuges ratifical-o quando } \\
\text { attingirem a idade exigida no } \S \\
8^{\circ} \text { do art. } 7^{\circ} \text {, perante o juiz e o } \\
\text { official do registro civil, e a } \\
\text { ratificação terá effeito } \\
\text { retroactivo, salva a disposição } \\
\text { do art. } 58 \S \S 1^{\circ} \text { e } 2^{\circ}\end{array}$ & $\begin{array}{l}\text { Art. 213. A anulação do } \\
\text { casamento da menor de } \\
\text { dezesseis anos ou menor de } \\
\text { dezoito será requerida: } \\
\text { I. Pelo próprio cônjuge menor. } \\
\text { II. Pelos seus representantes } \\
\text { legais. } \\
\text { III. Pelas pessoas designadas } \\
\text { no art. 190, naquela mesma } \\
\text { ordem. } \\
\text { Art. } 214 \text {. Podem, entretanto, } \\
\text { casar-se os referidos menores } \\
\text { para evitar a imposição ou o } \\
\text { cumprimento de pena } \\
\text { criminal. }\end{array}$ & $\begin{array}{l}\text { Art. 1.552. A anulação do } \\
\text { casamento dos menores de } \\
\text { dezesseis anos será requerida: } \\
\text { I - pelo próprio cônjuge menor; } \\
\text { II - por seus representantes } \\
\text { legais; } \\
\text { III - por seus ascendentes. }\end{array}$ \\
\hline $\begin{array}{l}\text { Art. } 70 \text {. A annullação do } \\
\text { casamento não obsta á } \\
\text { legitimidade do filho } \\
\text { concebido na constancia delle. }\end{array}$ & $\begin{array}{l}\text { Art. } 217 \text {. A anulação do } \\
\text { casamento não opta à } \\
\text { legitimidade do filho } \\
\text { concebido ou havido antes ou } \\
\text { na constância dele. }\end{array}$ & \\
\hline $\begin{array}{l}\text { Art. } 71 . \text { Tambem será } \\
\text { annullavel o casamento } \\
\text { quando um dos conjuges } \\
\text { houver consentido nelle por } \\
\text { erro essencial, em que } \\
\text { estivesse a respeito da pessoa } \\
\text { do outro. }\end{array}$ & $\begin{array}{l}\text { Art. 218. É também anulável o } \\
\text { casamento, se houve por parte } \\
\text { de um dos nubentes, ao } \\
\text { consentir, erro essência } \\
\text { quanto à pessoa do outro. }\end{array}$ & $\begin{array}{l}\text { Art. 1.556. O casamento pode } \\
\text { ser anulado por vício da } \\
\text { vontade, se houve por parte de } \\
\text { um dos nubentes, ao consentir, } \\
\text { erro essencial quanto à pessoa } \\
\text { do outro. }\end{array}$ \\
\hline $\begin{array}{l}\text { Art. } 72 \text {. Considera-se erro } \\
\text { essencial sobre a pessoa do } \\
\text { outro conjuge: }\end{array}$ & $\begin{array}{l}\text { Art. 219. Considera-se erro } \\
\text { essencial sobre a pessoa do } \\
\text { outro cônjuge: }\end{array}$ & $\begin{array}{l}\text { Art. } 1.557 \text {. Considera-se erro } \\
\text { essencial sobre a pessoa do } \\
\text { outro cônjuge: }\end{array}$ \\
\hline
\end{tabular}




\section{$\S 1^{\circ} \mathrm{A}$ ignorancia do seu estado. \\ $\S 2^{\circ} \mathrm{A}$ ignorancia de crime inafiançavel e não prescripto, commettido por elle antes do casamento.}

$\S 3^{\circ} \mathrm{A}$ ignorancia de defeito physico irremediavel e anterior, como a impotencia, e qualquer molestia incuravel ou transmissivel por contagio ou herança.
Art. 73. A annullação do casamento, nos casos do artigo antecedente, só póde ser pedida pelo outro conjuge dentro de dous annos, contados da sua data ou da data desta lei, si for anterior a ella.

Art. 74. A nullidade do casamento não póde ser pedida ex-officio, depois da morte de um dos conjuges.
I. O que diz respeito à identidade do outro cônjuge, sua honra e boa fama, sendo esse erro tal, que o seu conhecimento ulterior torne insuportável a vida em comum ao cônjuge enganado.

II. A ignorância de crime inafiançável, anterior ao casamento e definitivamente julgado por sentença condenatória.

III. A ignorância, anterior ao casamentro, de defeito písico irremediável ou de molestia grave e transmissível, por contágio ou herança, capaz de por em risco a saúde do outro cônjuge ou de sua descendência.

IV. O defloramento da mulher, ignorado pelo marido.

Art. 220. A anulação do casamento, nos casos do artigo antecedente, $n^{\circ}$ s I, II e III, só poderá demandar o outro cônjuge e, no caso do $\mathrm{n}^{\circ}$ IV, só o marido.

Art. 220. A annullação do casamento, nos casos artigo antecedente, só a poderá demandar o conjuge enganado.
I - o que diz respeito à sua identidade, sua honra e boa fama, sendo esse erro tal que o seu conhecimento ulterior torne insuportável a vida em comum ao cônjuge enganado;

II - a ignorância de crime, anterior ao casamento, que, por sua natureza, torne insuportável a vida conjugal;

III - a ignorância, anterior ao casamento, de defeito físico irremediável, ou de moléstia grave e transmissível, pelo contágio ou herança, capaz de pôr em risco a saúde do outro cônjuge ou de sua descendência; IV - a ignorância, anterior ao casamento, de doença mental grave que, por sua natureza, torne insuportável a vida em comum ao cônjuge enganado.

Art. 1.559. Somente o cônjuge que incidiu em erro, ou sofreu coação, pode demandar a anulação do casamento; mas a coabitação, havendo ciência do vício, valida o ato, ressalvadas as hipóteses dos incisos III e IV do art. 1.557.

Art. 1.560. O prazo para ser intentada a ação de anulação do casamento, a contar da data da celebração, é de:

I - cento e oitenta dias, no caso do inciso IV do art. 1.550;

II - dois anos, se incompetente a autoridade celebrante;

III - três anos, nos casos dos incisos I a IV do art. 1.557;

IV - quatro anos, se houver coação.

$\S 1^{\circ}$ Extingue-se, em cento e oitenta dias, o direito de anular o casamento dos menores de dezesseis anos, contado o prazo para o menor do dia em que perfez essa idade; e da data do 


\begin{tabular}{|c|c|c|}
\hline & & $\begin{array}{l}\text { casamento, para seus } \\
\text { representantes legais ou } \\
\text { ascendentes. } \\
\S 2^{\circ} \mathrm{Na} \text { hipótese do inciso V do } \\
\underline{\text { art. } 1.550} \text { o prazo para anulação } \\
\text { do casamento é de cento e } \\
\text { oitenta dias, a partir da data em } \\
\text { que o mandante tiver } \\
\text { conhecimento da celebração. }\end{array}$ \\
\hline $\begin{array}{l}\text { Art. 75. Quando o casamento } \\
\text { nullo ou annullavel tiver sido } \\
\text { contrahido de boa fé, } \\
\text { produzirá os seus effeitos } \\
\text { civis, quer em relação aos } \\
\text { conjuges, quer em relação aos } \\
\text { filhos, ainda que estes fossem } \\
\text { havidos antes do mesmo } \\
\text { casamento. Todavia, si só um } \\
\text { dos conjuges o tiver } \\
\text { contrahido de boa fé, o } \\
\text { casamento só produzirá effeito } \\
\text { em favor delle e dos filhos. }\end{array}$ & $\begin{array}{l}\text { Art. 221. Embora nulo ou } \\
\text { anulável, quando contraído de } \\
\text { boa fé por ambos os cônjuges, } \\
\text { o casamento, em relação a } \\
\text { estes como aos filhos, produz } \\
\text { todos os efeitos civis desde a } \\
\text { data da sua celebração. } \\
\text { Art. } 221 \text {. Embora annullavel, } \\
\text { ou mesmo nullo se contrahido } \\
\text { de bôa fé por ambos os } \\
\text { conjuges, o casamento, em } \\
\text { relação a estes aos filhos, } \\
\text { produz todos os effeitos civis } \\
\text { até ao dia da sentença } \\
\text { annullatoria. }\end{array}$ & $\begin{array}{l}\text { Art. 1.561. Embora anulável ou } \\
\text { mesmo nulo, se contraído de } \\
\text { boa-fé por ambos os cônjuges, o } \\
\text { casamento, em relação a estes } \\
\text { como aos filhos, produz todos } \\
\text { os efeitos até o dia da sentença } \\
\text { anulatória. } \\
\S 1^{\text {o }} \text { Se um dos cônjuges estava } \\
\text { de boa-fé ao celebrar o } \\
\text { casamento, os seus efeitos civis } \\
\text { só a ele e aos filhos } \\
\text { aproveitarão. } \\
\S 2^{\circ} \text { Se ambos os cônjuges } \\
\text { estavam de má-fé ao celebrar o } \\
\text { casamento, os seus efeitos civis } \\
\text { só aos filhos aproveitarão. } \\
\text { Art. } 1.563 \text {. A sentença que } \\
\text { decretar a nulidade do } \\
\text { casamento retroagirá à data da } \\
\text { sua celebração, sem prejudicar a } \\
\text { aquisição de direitos, a título } \\
\text { oneroso, por terceiros de boa-fé, } \\
\text { nem a resultante de sentença } \\
\text { transitada em julgado. }\end{array}$ \\
\hline $\begin{array}{l}\text { Art. 76. A declaração da } \\
\text { nullidade do casamento será } \\
\text { pedida por acção summaria e } \\
\text { independente de conciliação. }\end{array}$ & $\begin{array}{l}\text { Art. 222. A nulidade do } \\
\text { casamento processar-se-á por } \\
\text { ação ordinária, na qual será } \\
\text { nomeado curador que o } \\
\text { defenda. }\end{array}$ & \\
\hline $\begin{array}{l}\text { Art. 77. As causas de } \\
\text { nullidade ou annullação do } \\
\text { casamento e de divorcio, } \\
\text { movidas entre os conjuges, } \\
\text { serão precedidas de uma } \\
\text { petição do autor, documentada } \\
\text { quanto baste para justificar a } \\
\text { separação dos conjuges, que o } \\
\text { juiz concederá com a possivel } \\
\text { brevidade. }\end{array}$ & $\begin{array}{l}\text { Art. 223. Antes de mover a } \\
\text { ação de nulidade do } \\
\text { casamento, a de anulação, ou } \\
\text { a de desquite, requererá o } \\
\text { autor, com documentos que a } \\
\text { autorizem, a separação de } \\
\text { corpos, que será concedida } \\
\text { pelo juiz com a possível } \\
\text { brevidade. }\end{array}$ & $\begin{array}{l}\text { Art. 1.562. Antes de mover a } \\
\text { ação de nulidade do casamento, } \\
\text { a de anulação, a de separação } \\
\text { judicial, a de divórcio direto ou } \\
\text { a de dissolução de união estável, } \\
\text { poderá requerer a parte, } \\
\text { comprovando sua necessidade, a } \\
\text { separação de corpos, que será } \\
\text { concedida pelo juiz com a } \\
\text { possível brevidade. }\end{array}$ \\
\hline
\end{tabular}




\begin{tabular}{|c|c|c|}
\hline & $\begin{array}{l}\text { Art. } 224 \text {. Concedida a } \\
\text { separação, a mulher poderá } \\
\text { pedir os alimentos } \\
\text { provisionais, que lhe serão } \\
\text { arbitrados, na fôrma do art. } \\
400 \text {. }\end{array}$ & \\
\hline $\begin{array}{l}\text { Art. } 78 \text {. Concedida a } \\
\text { separação, a mulher poderá } \\
\text { pedir os alimentos } \\
\text { provisionaes, que lhe serão } \\
\text { arbitrados, na fórma do direito } \\
\text { civil, mesmo antes da } \\
\text { conciliação. }\end{array}$ & & \\
\hline $\begin{array}{l}\text { Art. 79. Quando o casamento } \\
\text { for declarado nullo por culpa } \\
\text { de um dos conjuges, este } \\
\text { perderá todas as vantagens } \\
\text { havidas do outro e ficará, não } \\
\text { obstante, obrigado a cumprir } \\
\text { as promessas que lhe houver } \\
\text { feito no respectivo contracto } \\
\text { ante-nupcial. }\end{array}$ & & $\begin{array}{l}\text { Art. 1.564. Quando o casamento } \\
\text { for anulado por culpa de um dos } \\
\text { cônjuges, este incorrerá: } \\
\text { I - na perda de todas as } \\
\text { vantagens havidas do cônjuge } \\
\text { inocente; } \\
\text { II - na obrigação de cumprir as } \\
\text { promessas que lhe fez no } \\
\text { contrato antenupcial. }\end{array}$ \\
\hline \multicolumn{3}{|c|}{ DO DIVÓRCIO } \\
\hline $\begin{array}{l}\text { Art. } 80 \text {. A acção do divorcio } \\
\text { só compete aos conjuges e } \\
\text { extingue-se pela morte de } \\
\text { qualquer delles. }\end{array}$ & $\begin{array}{l}\text { Art. } 316 \text {. A ação de desquite } \\
\text { será ordinária e somente } \\
\text { competira aos cônjuges. } \\
\text { (Revogado pela Lei } \mathrm{n}^{\circ} 6.515 \text {, } \\
\text { de 1977). }\end{array}$ & $\begin{array}{l}\text { Art. 1.572. Qualquer dos } \\
\text { cônjuges poderá propor a ação } \\
\text { de separação judicial, } \\
\text { imputando ao outro qualquer ato } \\
\text { que importe grave violação dos } \\
\text { deveres do casamento e torne } \\
\text { insuportável a vida em comum. }\end{array}$ \\
\hline $\begin{array}{l}\text { Art. } 81 \text {. Si o conjuge, a quem } \\
\text { competir a acção, for incapaz } \\
\text { de exercel-a, poderá ser } \\
\text { representado por qualquer dos } \\
\text { seus ascendentes, } \\
\text { descendentes ou irmãos, e na } \\
\text { falta delles pelos parentes mais } \\
\text { proximos, observada a ordem } \\
\text { em que são mencionados neste } \\
\text { artigo. }\end{array}$ & $\begin{array}{l}\text { Art. } 316 \text {, Parágrafo único. Se, } \\
\text { porém, o cônjuge for incapaz } \\
\text { de exerce-la, poderá ser } \\
\text { representado por qualquer } \\
\text { ascendente, ou irmão. }\end{array}$ & \\
\hline $\begin{array}{l}\text { Art. } 82 \text {. O pedido de divorcio } \\
\text { só póde fundar-se em algum } \\
\text { dos seguintes motivos: } \\
\S 1^{\circ} \text { Adulterio. }\end{array}$ & $\begin{array}{l}\text { Art. } 317 \text {. A ação de desquite } \\
\text { só se pode fundar em algum } \\
\text { dos seguintes motivos: }\end{array}$ & $\begin{array}{l}\text { Art. 1.573. Podem caracterizar a } \\
\text { impossibilidade da comunhão } \\
\text { de vida a ocorrência de algum } \\
\text { dos seguintes motivos: }\end{array}$ \\
\hline
\end{tabular}




\begin{tabular}{|c|c|c|}
\hline $\begin{array}{l}\S 2^{\circ} \text { Sevicia, ou injuria grave. } \\
\S 3^{\circ} \text { Abandono voluntario do } \\
\text { domicilio conjugal e } \\
\text { prolongado por dous annos } \\
\text { continuos. } \\
\S 4^{\circ} \text { Mutuo consentimento dos } \\
\text { conjuges, si forem casados ha } \\
\text { mais de dous annos. }\end{array}$ & $\begin{array}{l}\text { (Revogado pela Lei n }{ }^{\circ} 6.515 \\
\frac{\text { de } 1977)}{\text { I. Adultério. }} \\
\text { II. Tentativa de morte. } \\
\text { III. Sevicia, ou injuria grave. } \\
\text { IV. Abandono voluntário do } \\
\text { lar conjugal, durante dois anos } \\
\text { contínuos. } \\
\text { Art. } 318 \text {. Dar-se-á também o } \\
\text { desquite por mutuo } \\
\text { consentimento dos cônjuges, } \\
\text { se forem casados por mais de } \\
\text { dois anos, manifestado } \\
\text { perante o juiz e devidamente } \\
\text { homologado. }\end{array}$ & $\begin{array}{l}\text { I - adultério; } \\
\text { II - tentativa de morte; } \\
\text { III - sevícia ou injúria grave; } \\
\text { IV - abandono voluntário do lar } \\
\text { conjugal, durante um ano } \\
\text { contínuo; } \\
\text { V - condenação por crime } \\
\text { infamante; } \\
\text { VI - conduta desonrosa. } \\
\text { Parágrafo único. O juiz poderá } \\
\text { considerar outros fatos que } \\
\text { tornem evidente a } \\
\text { impossibilidade da vida em } \\
\text { comum. }\end{array}$ \\
\hline $\begin{array}{l}\text { Art. 83. O adulterio deixará de } \\
\text { ser motivo para o divorcio: } \\
\S 1^{\circ} \mathrm{Si} \text { o réo for a mulher e } \\
\text { tiver sido violentada pelo } \\
\text { adultero. } \\
\S 2^{\circ} \mathrm{Si} \text { o autor houver } \\
\text { concorrido para que o réo o } \\
\text { commettesse. } \\
\S 3^{\circ} \text { Quando tiver sobrevindo } \\
\text { perdão da parte do autor. } \\
\text { Art. } 84 \text {. Presume-se perdoado } \\
\text { o adulterio quando o conjuge } \\
\text { innocente, depois de ter } \\
\text { conhecimento delle, houver } \\
\text { cohabitado com o culpado. }\end{array}$ & $\begin{array}{l}\text { Art. } 319 . \text { O adultério deixará } \\
\text { de ser motivo para desquite: } \\
\text { (Revogado pela Lei } \mathrm{n}^{\circ} 6.515 \text {, } \\
\text { de 1977). } \\
\text { I. Se o autor houver } \\
\text { concorrido para que o réu o } \\
\text { cometesse. } \\
\text { (Vide Decreto do Poder } \\
\underline{\text { Legislativo } \mathrm{n}^{\circ} 3.725 \text {, de }} \\
\underline{\text { 1919). }} \\
\text { II. Se o cônjuge inocente lhe } \\
\text { houver perdoado. }\end{array}$ & \\
\hline $\begin{array}{l}\text { Art. 85. Para obterem o } \\
\text { divorcio por mutuo } \\
\text { consentimento deverão os } \\
\text { conjuges apresentar-se } \\
\text { pessoalmente ao juiz, levando } \\
\text { a sua petição escripta por um e } \\
\text { assignada por ambos, ou ao } \\
\text { seu rogo, si não souberem } \\
\text { escrever, e instruida com os } \\
\text { seguintes documentos: } \\
\S 1^{\circ} \text { A certidão do casamento. } \\
\S 2^{\circ} \text { A declaração de todos os } \\
\text { seus bens e a partilha que } \\
\text { houverem concordado fazer } \\
\text { delles. }\end{array}$ & $\begin{array}{l}\text { Art. } 319 \text {, Parágrafo único. } \\
\text { Presume-se perdoado o } \\
\text { adultério, quando o cônjuge } \\
\text { inocente, conhecendo-o, } \\
\text { coabitar com o culpado. }\end{array}$ & $\begin{array}{l}\text { Art. 1.574. Dar-se-á a separação } \\
\text { judicial por mútuo } \\
\text { consentimento dos cônjuges se } \\
\text { forem casados por mais de um } \\
\text { ano e o manifestarem perante o } \\
\text { juiz, sendo por ele devidamente } \\
\text { homologada a convenção. }\end{array}$ \\
\hline
\end{tabular}


$\S 3^{\circ}$ A declaração do accordo que houverem tomado sobre a posse dos filhos menores, si os tiverem.

$\S 4^{\circ}$ A declaração da contribuição, com que cada um delles concorrerá para a criação e educação dos mesmos filhos, ou da pensão alimenticia do marido á mulher, si esta não ficar com bens sufficientes para manterse.

$\S 5^{\circ}$ Traslado da nota do contracto ante-nupcial, si tiver havido.

Art. 86. Recebidos os documentos referidos e ouvidos separadamente os dous conjuges sobre o motivo do divorcio pelo juiz, este fixar-lhes-ha um prazo nunca menor de 15 dias nem maior de 30 para voltarem a ratificar, ou retractar o seu pedido.

Art. 87. Si, findo este prazo, voltarem ambos a ratificar o pedido, o juiz, depois de fazer autoar a petição com todos os documentos do art. 85, julgará por sentença o accordo, no prazo de duas audiencias, e appellará ex-officio. Si ambos os conjuges retractarem $o$ pedido, o juiz restituir-lhes-ha todas as peças recebidas, e si sómente um delles retractar-se, a este entregará as mesmas peças, na presença do outro.

Art. 88. O divorcio não dissolve o vinculo conjugal, mas autoriza a separação indefinida dos corpos e faz cassar o regimen dos bens, como si o casamento fosse dissolvido.
Art. 322. A sentença do desquite autoriza a separação dos conjugues, e põe termo ao regime matrimonial dos bens, como se o casamento fosse anulado (art. 267, n. III). (Vide Decreto do Poder Legislativo $\mathrm{n}^{\mathrm{o}} 3.725$, de 1919).

(Revogado pela Lei $\mathrm{n}^{\mathrm{O}}$ 6.515, de 1977).
Art. 1.575. A sentença de separação judicial importa a separação de corpos e a partilha de bens.

Parágrafo único. A partilha de bens poderá ser feita mediante proposta dos cônjuges e homologada pelo juiz ou por este decidida. 


\begin{tabular}{|c|c|c|}
\hline & & $\begin{array}{l}\text { Art. 1.576. A separação judicial } \\
\text { põe termo aos deveres de } \\
\text { coabitação e fidelidade } \\
\text { recíproca e ao regime de bens. }\end{array}$ \\
\hline $\begin{array}{l}\text { Art. } 89 . \text { Os conjuges } \\
\text { divorciados podem } \\
\text { reconciliar-se em qualquer } \\
\text { tempo, mas não restabelecer o } \\
\text { regimen dos bons, que, uma } \\
\text { vez partilhados, serão } \\
\text { administrados e alienados sem } \\
\text { dependencia de autorização do } \\
\text { marido, ou outorga da mulher. }\end{array}$ & $\begin{array}{l}\text { Parágrafo único. A } \\
\text { reconciliação em nada } \\
\text { prejudicará os direitos de } \\
\text { terceiros, adquiridos antes e } \\
\text { durante o desquite, seja qual } \\
\text { for o regime dos bens. }\end{array}$ & $\begin{array}{l}\text { Parágrafo único. A } \\
\text { reconciliação em nada } \\
\text { prejudicará o direito de } \\
\text { terceiros, adquirido antes e } \\
\text { durante o estado de separado, } \\
\text { seja qual for o regime de bens. }\end{array}$ \\
\hline $\begin{array}{l}\text { Art. 90. A sentença do } \\
\text { divorcio litigioso mandará } \\
\text { entregar os filhos communs e } \\
\text { menores ao conjuge innocente } \\
\text { e fixará a quota com que o } \\
\text { culpado deverá concorrer para } \\
\text { educação delles, assim como a } \\
\text { contribuição do marido para } \\
\text { sustentação da mulher, si esta } \\
\text { for innocente e pobre. }\end{array}$ & $\begin{array}{l}\text { Art. 320. No desquite judicial, } \\
\text { sendo a mulher inocente e } \\
\text { pobre, prestar-lhe-á o marido } \\
\text { a pensão alimentícia, que o } \\
\text { juiz fixar. } \\
\text { (Revogado pela Lei no } 6.515, \\
\text { de 1977). } \\
\text { Art. } 321 . \text { O juiz fixará } \\
\text { também a quota com que, para } \\
\text { criação e educação dos filhos, } \\
\text { deve concorrer o conjugue } \\
\text { culpado, ou ambos, se um e } \\
\text { outro o forem. } \\
\text { (Revogado pela Lei } n^{\circ} 6.515, \\
\text { de } 1977)\end{array}$ & $\begin{array}{l}\text { Art. 1.579. O divórcio não } \\
\text { modificará os direitos e deveres } \\
\text { dos pais em relação aos filhos. } \\
\text { Parágrafo único. Novo } \\
\text { casamento de qualquer dos pais, } \\
\text { ou de ambos, não poderá } \\
\text { importar restrições aos direitos e } \\
\text { deveres previstos neste artigo. }\end{array}$ \\
\hline $\begin{array}{l}\text { Art. 91. O divorcio dos } \\
\text { conjuges, que tiverem filhos } \\
\text { communs, não annulla o dote, } \\
\text { que continuará sujeito aos } \\
\text { onus do casamento, mas } \\
\text { passará a ser administrado pela } \\
\text { mulher, si ella for o conjuge } \\
\text { innocente. Si o divorcio for } \\
\text { promovido por mutuo } \\
\text { consentimento, a } \\
\text { administração do dote será } \\
\text { regulada na conformidade das } \\
\text { declarações do art. } 85 \text {. }\end{array}$ & & \\
\hline $\begin{array}{l}\text { Art. } 92 . \text { Si a mulher } \\
\text { condemnada na acção do } \\
\text { divorcio continuar a usar do } \\
\text { nome do marido, poderá ser } \\
\text { accusada, por este como } \\
\text { incursa nas penas dos arts. } 301 \\
\text { e } 302 \text { do codigo criminal. }\end{array}$ & $\begin{array}{l}\text { Art. 324. A mulher condenada } \\
\text { na ação de desquite perde o } \\
\text { direito a usar o nome do } \\
\text { marido (art. 240). } \\
\text { (Revogado pela Lei } \mathrm{n}^{\circ} 6.515 \text {, } \\
\text { de 1977). }\end{array}$ & $\begin{array}{l}\text { Art. } 1571, \S 2^{\circ} \text { Dissolvido o } \\
\text { casamento pelo divórcio direto } \\
\text { ou por conversão, o cônjuge } \\
\text { poderá manter o nome de } \\
\text { casado; salvo, no segundo caso, } \\
\text { dispondo em contrário a } \\
\text { sentença de separação judicia }\end{array}$ \\
\hline
\end{tabular}




\section{DA DISSOLUÇÃO DO CASAMENTO}

Art. 93. O casamento válido só se dissolve pela morte de um dos conjuges, e neste caso proceder-se-ha a respeito dos filhos e dos bens do casal na conformidade do direito civil.

Art. 94. Todavia, si o conjuge fallecido for o marido, e a mulher não for binuba, esta the succederá nos seus direitos sobre a pessoa e os bens dos filhos menores, emquanto se conservar viuva. $\mathrm{Si}$, porém, for binuba, ou estiver separada do marido por culpa sua, não será admittida a administrar os bens delles, nem como tutora ou curadora.
Art. 315, Parágrafo único. O casamento valido só se dissolve pela morte de um dos conjugues, não se lhe aplicando a preempção estabelecida neste Código, art. 10 , Segunda parte.
Art. $1571, \S 1^{\circ} \mathrm{O}$ casamento válido só se dissolve pela morte de um dos cônjuges ou pelo divórcio, aplicando-se a presunção estabelecida neste Código quanto ao ausente.

\section{DA POSSE DOS FILHOS}

Art. 95. Declarado nullo ou annullado o casamento sem culpa de algum dos contrahentes, e havendo filhos communs, a mãe terá o direito á posse das filhas, emquanto forem menores, e a dos filhos até completarem a idade de 6 annos.

Art. 96. Si, porém, tiver havido culpa de um dos contrahentes, só ao outro competirá a posse dos filhos, salvo si o culpado for a mãe, que, ainda neste caso, poderá conserval-os comsigo até a idade de 3 annos, sem distincção de sexo.

Art. 97. No caso de divorcio, observar-se-ha o disposto nos arts. 85 e 90, de accordo com a clausula final do artigo antecedente.
Art. 325. No caso de dissolução da sociedade conjugal por desquite amigável, observar-se-á o que os conjugues acordarem sobre a guarda dos filhos.

(Revogado pela Lei $\mathrm{n}^{\mathrm{o}}$ 6.515, de 1977).

Art. 326. Sendo o desquite judicial, ficarão os filhos menores com o conjugue inocente.

$\S 1^{\circ} \mathrm{Se}$ ambos forem culpados, a mãe terá direito de conservar em sua companhia as filhas, enquanto menores, e os filhos até a idade de seis anos.

$\S 2^{\circ}$ Os filhos maiores de seis anos serão entregues à guarda do pai.

Art. 326. Sendo desquite judicial, ficarão os filhos
Art. 1.583. No caso de dissolução da sociedade ou do vínculo conjugal pela separação judicial por mútuo consentimento ou pelo divórcio direto consensual, observar-se-á o que os cônjuges acordarem sobre a guarda dos filhos.

Art. 1.583. A guarda será unilateral ou compartilhada. (Redação dada pela Lei $\mathrm{n}^{\circ}$ 11.698, de 2008).

$\S 1^{\mathrm{o}}$ Compreende-se por guarda unilateral a atribuída a um só dos genitores ou a alguém que o substitua (art. 1.584, § 5o ) e, por guarda compartilhada a responsabilização conjunta e o exercício de direitos e deveres do pai e da mãe que não vivam sob o mesmo teto, concernentes ao poder familiar dos filhos comuns. (Incluído pela Lei $\mathrm{n}^{\circ} 11.698$, de 2008). 
Art. 98. Fica sempre salvo aos paes concordarem particularmente sobre a posse dos filhos, como lhes parecer melhor, em beneficio destes. menores com o cônjuge

inocente.

(Redação dada pela Lei ${ }^{\circ}$

4.121, de 1962).

(Revogado pela Lei $\mathrm{n}^{\circ} 6.515$,

de 1977).

$\S 1^{\circ} \mathrm{Se}$ ambos os cônjuges forem culpados ficarão em poder da mãe os filhos menores, salvo se o juiz verificar que de tal solução possa advir prejuízo de ordem moral para êles.

(Redação dada pela Lei ${ }^{\circ}$ 4.121, de 1962). $\S 2^{\circ}$ Verificado que não devem os filhos permanecer em poder da mãe nem do pai deferirá o juiz a sua guarda a pessoa notòriamente idônea da família de qualquer dos cônjuges ainda que não mantenha relações sociais com o outro a quem, entretanto, será assegurado o direito de visita.

(Redação dada pela Lei ${ }^{\circ}$ 4.121, de 1962).

Art. 327. Havendo motivos graves, poderá o juiz, em qualquer caso, a bem dos filhos, regular por maneira diferente da estabelecida nos artigos anteriores a situação deles para com os pais.

(Revogado pela Lei $\mathrm{n}^{\circ}$ 6.515, de 1977).

Parágrafo único. Se todos os filhos couberem a um só conjugue, fixará o juiz a contribuição com que, para o sustento deles, haja de concorrer o outro.

Art. 328. No caso de anulação do casamento, havendo filhos comuns, observar-se-á o disposto nos arts. 326 e 327.

(Revogado pela Lei $\mathrm{n}^{\circ} 6.515$, de 1977).
$\S 2^{\circ}$ A guarda unilateral será atribuída ao genitor que revele melhores condições para exercêla e, objetivamente, mais aptidão para propiciar aos filhos os seguintes fatores:

(Incluído pela Lei $\mathrm{n}^{\circ} 11.698$, de 2008).

$\S 2^{\mathrm{o}} \mathrm{Na}$ guarda compartilhada, o tempo de convívio com os filhos deve ser dividido de forma equilibrada com a mãe e com o pai, sempre tendo em vista as condições fáticas e os interesses dos filhos:

(Redação dada pela Lei $\mathrm{n}^{\mathrm{O}}$ 13.058, de 2014)

I - afeto nas relações com o genitor e com o grupo familiar; (Incluído pela Lei $\mathrm{n}^{\circ} 11.698$, de 2008).

I - (revogado);

(Redação dada pela Lei $\mathrm{n}^{\mathrm{O}}$ 13.058, de 2014)

II - saúde e segurança;

(Incluído pela Lei $\mathrm{n}^{\circ} 11.698$, de 2008).

II - (revogado);

(Redação dada pela Lei $\mathrm{n}^{\circ}$ 13.058, de 2014)

III - educação.

(Incluído pela Lei $\mathrm{n}^{\circ} 11.698$, de 2008).

III - (revogado).

${\text { (Redação dada pela Lei } \mathrm{n}^{\mathrm{O}}}$ 13.058, de 2014)

$\S 3^{\circ}$ A guarda unilateral obriga o pai ou a mãe que não a detenha a supervisionar os interesses dos filhos.

(Incluído pela Lei $\mathrm{n}^{\circ} 11.698$, de 2008).

$\S 3^{\circ} \mathrm{Na}$ guarda compartilhada, a cidade considerada base de moradia dos filhos será aquela que melhor atender aos interesses dos filhos.

(Redação dada pela Lei $\mathrm{n}^{\mathrm{O}}$ 13.058, de 2014)

$\S 4^{\circ}$ (VETADO). 
Art. 329. A mãe, que contrai novas núpcias, não perde $o$ direito a ter consigo os filhos, que só lhe poderão ser retirados, mandando o juiz, provado que ela, ou o padrasto, não os trate convenientemente (art. 248, n. I, e 393).

(Vide Decreto do Poder Legislativo $\mathrm{n}^{0} 3.725$, de 1919).
(Incluído pela Lei $\mathrm{n}^{\mathrm{o}} 11.698$, de 2008).

$\S 5^{\circ}$ A guarda unilateral obriga o pai ou a mãe que não a detenha a supervisionar os interesses dos filhos, e, para possibilitar tal supervisão, qualquer dos genitores sempre será parte legítima para solicitar informações e/ou prestação de contas, objetivas ou subjetivas, em assuntos ou situações que direta ou indiretamente afetem a saúde física e psicológica e a educação de seus filhos.

(Incluído pela Lei $\mathrm{n}^{\circ} 13.058$, de 2014)

Art. 1.584. Decretada a separação judicial ou o divórcio, sem que haja entre as partes acordo quanto à guarda dos filhos, será ela atribuída a quem revelar melhores condições para exercê-la.

Parágrafo único. Verificando que os filhos não devem permanecer sob a guarda do pai ou da mãe, o juiz deferirá a sua guarda à pessoa que revele compatibilidade com a natureza da medida, de preferência levando em conta o grau de parentesco e relação de afinidade e afetividade, de acordo com o disposto na lei específica.

Art. 1.584. A guarda, unilateral ou compartilhada, poderá ser: (Redação dada pela Lei $\mathrm{n}^{\circ}$ 11.698, de 2008).

I - requerida, por consenso, pelo pai e pela mãe, ou por qualquer deles, em ação autônoma de separação, de divórcio, de dissolução de união estável ou em medida cautelar; (Incluído pela Lei $\mathrm{n}^{\circ} 11.698$, de 2008). 
II - decretada pelo juiz, em atenção a necessidades específicas do filho, ou em razão da distribuição de tempo necessário ao convívio deste com o pai e com a mãe. (Incluído pela Lei $\mathrm{n}^{\circ} 11.698$, de 2008).

$\S 1^{\circ} \mathrm{N}$ a audiência de conciliação, o juiz informará ao pai e à mãe o significado da guarda compartilhada, a sua importância, a similitude de deveres e direitos atribuídos aos genitores e as sanções pelo descumprimento de suas cláusulas.

(Incluído pela Lei $\mathrm{n}^{\circ} 11.698$, de 2008).

$\S 2^{\mathrm{o}}$ Quando não houver acordo entre a mãe e o pai quanto à guarda do filho, será aplicada, sempre que possível, a guarda compartilhada.

(Incluído pela Lei $\mathrm{n}^{\circ} 11.698$, de 2008).

$\S 2^{\circ}$ Quando não houver acordo entre a mãe e o pai quanto à guarda do filho, encontrando-se ambos os genitores aptos a exercer o poder familiar, será aplicada a guarda compartilhada, salvo se um dos genitores declarar ao magistrado que não deseja a guarda do menor.

(Redação dada pela Lei $\mathrm{n}^{\circ}$ 13.058, de 2014)

$\S 3^{\circ}$ Para estabelecer as atribuições do pai e da mãe e os períodos de convivência sob guarda compartilhada, o juiz, de ofício ou a requerimento do Ministério Público, poderá basear-se em orientação técnicoprofissional ou de equipe interdisciplinar.

(Incluído pela Lei $\mathrm{n}^{\circ} 11.698$, de 2008).

$\S 3^{\circ}$ Para estabelecer as atribuições do pai e da mãe e os períodos de convivência sob guarda compartilhada, o juiz, de ofício ou a requerimento do Ministério Público, poderá 
basear-se em orientação técnicoprofissional ou de equipe interdisciplinar, que deverá visar à divisão equilibrada do tempo com o pai e com a mãe.

(Redação dada pela Lei $\mathrm{n}^{\circ}$ 13.058, de 2014)

$\S 4^{\circ} \mathrm{A}$ alteração não autorizada ou o descumprimento imotivado de cláusula de guarda, unilateral ou compartilhada, poderá implicar a redução de prerrogativas atribuídas ao seu detentor, inclusive quanto ao número de horas de convivência com o filho.

(Incluído pela Lei $\mathrm{n}^{\circ} 11.698$, de 2008).

$\S 4^{\circ}$ A alteração não autorizada ou o descumprimento imotivado de cláusula de guarda unilateral ou compartilhada poderá implicar a redução de prerrogativas atribuídas ao seu detentor.

(Redação dada pela Lei $\mathrm{n}^{\circ}$ 13.058, de 2014)

$\S 5^{\circ}$ Se o juiz verificar que o filho não deve permanecer sob a guarda do pai ou da mãe, deferirá a guarda à pessoa que revele compatibilidade com a natureza da medida, considerados, de preferência, o grau de parentesco e as relações de afinidade e afetividade. (Incluído pela Lei $\mathrm{n}^{\circ} 11.698$, de 2008).

$\S 5^{\circ}$ Se o juiz verificar que o filho não deve permanecer sob a guarda do pai ou da mãe, deferirá a guarda a pessoa que revele compatibilidade com a natureza da medida, considerados, de preferência, o grau de parentesco e as relações de afinidade e afetividade.

(Redação dada pela Lei $\mathrm{n}^{\circ}$ 13.058, de 2014)

$\S 6^{\circ}$ Qualquer estabelecimento público ou privado é obrigado a prestar informações a qualquer dos genitores sobre os filhos destes, sob pena de multa de R\$ 
200,00 (duzentos reais) a $\mathrm{R} \$$ 500,00 (quinhentos reais) por dia pelo não atendimento da solicitação.

(Incluído pela Lei $\mathrm{n}^{\circ} 13.058$, de $\underline{\text { 2014) }}$

Art. 1.585. Em sede de medida cautelar de separação de corpos, aplica-se quanto à guarda dos filhos as disposições do artigo antecedente.

Art. 1.585. Em sede de medida cautelar de separação de corpos, em sede de medida cautelar de guarda ou em outra sede de fixação liminar de guarda, a decisão sobre guarda de filhos, mesmo que provisória, será proferida preferencialmente após a oitiva de ambas as partes perante o juiz, salvo se a proteção aos interesses dos filhos exigir a concessão de liminar sem a oitiva da outra parte, aplicando-se as disposições do art. 1.584.

(Redação dada pela Lei $\mathrm{n}^{\circ}$ 13.058, de 2014)

Art. 1.586. Havendo motivos graves, poderá o juiz, em qualquer caso, a bem dos filhos, regular de maneira diferente da estabelecida nos artigos antecedentes a situação deles para com os pais.

Art. 1.587. No caso de invalidade do casamento, havendo filhos comuns, observar-se-á o disposto nos arts. 1.584 e 1.586.

Art. 1.588. O pai ou a mãe que contrair novas núpcias não perde o direito de ter consigo os filhos, que só lhe poderão ser retirados por mandado judicial, 


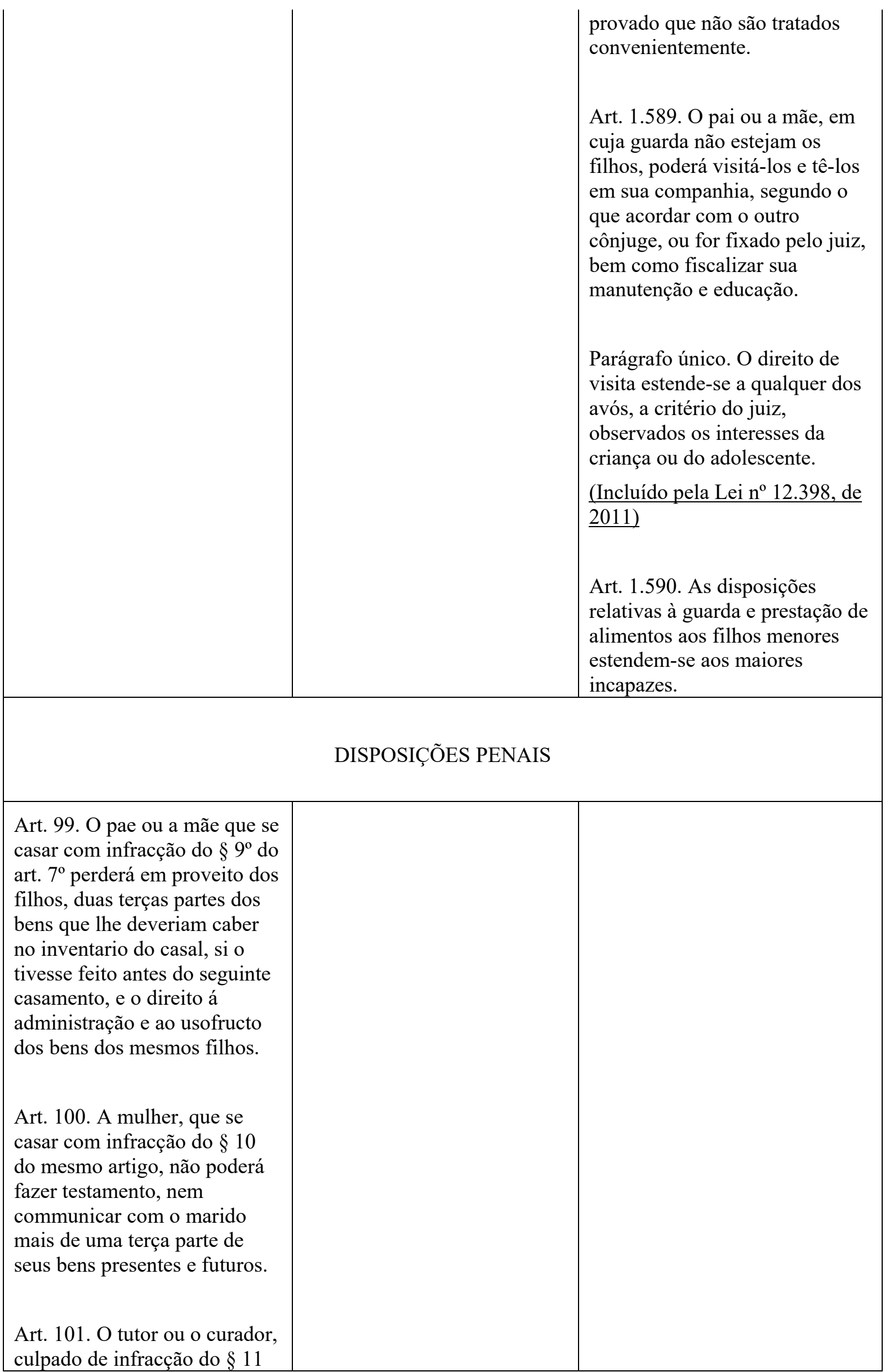


do citado art. $7^{\circ}$, será obrigado a dar ao conjuge do pupillo ou curatelado quanto baste para igualar os bens daquelle aos deste.

Art. 102. Na mesma pena do artigo antecedente incorrera o juiz, ou o escrivão culpado da infracção do $\S 12$ do mesmo art. $7^{\circ}$, e bem assim na de perder o cargo, com inhabilitação para exercer outro, durante 10 annos.

Art. 103. A lei presume culpado o tutor, o curador, o juiz e o escrivão, nos casos dos $\S \S 11$ e 12 do art. $7^{\circ}$

Art. 104. O official do registro civil, que publicar proclamas sem autorização de ambos os contrahentes, ou der a certidão do art. $3^{\circ}$ sem lhe terem sido apresentados os documentos exigidos pelo art. $1^{\circ}$, ou pendendo impedimento ainda não julgado improcedente, ou deixar de declarar os impedimentos, que lhe forem apresentados, ou que lhe constarem com certeza e puderem ser oppostos por elle ex-officio, ficará sujeito á multa de $20 \$$ a $200 \$$ para a respectiva Municipalidade.

Art. 105. Na mesma multa incorrerá o juiz que assistir ao casamento antes de levantados os impedimentos oppostos contra algum dos contrahentes, ou deixar de recebel-os, quando opportunamente offerecidos, nos termos do art. 13 , ou de oppol-os, quando the constarem, ou deverem ser oppostos ex-officio, ou recusar-se a assistir ao casamento, sem motivo justificado. 
Art. 106. Si o casamento for declarado nullo, ou annullado, ou deixar de effectuar-se por culpa do juiz, ou do official do registro civil, o culpado perderá o seu logar e ficará, durante 10 annos, inhibido de exercer qualquer outro cargo publico, ainda mesmo gratuito.

Art. 107. As penas

comminadas neste capitulo serão applicadas sem prejuizo das que aos respectivos delictos estiverem comminadas no codigo criminal e no decreto n. 9886 de 7 de março de 1888 . 